\title{
THE EVOLUTION OF TYRANT TROPES IN GREEK TRAGEDY
}

BY

CHARLIE HANN

\begin{abstract}
A Thesis
submitted to the Victoria University of Wellington

in fulfilment of the requirements for the degree of

Master of Arts

supervised by Dr James Kierstead,

Senior Lecturer in Classics
\end{abstract}

Victoria University of Wellington

(2020) 
To my parents

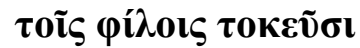

Meis caris parentibus 


\begin{abstract}
:
Tyranny (tyrannis) is a name given to a type of Greek monarchy that came into being in the seventh century B.C.E. The democratisation of Greece and the transference of aristocratic ideas of equality and liberty to the whole citizen population led the vilification of tyranny as the opposite of democracy and its extensive use as a foil for democracy in Athenian politics. This political idea made its way into literature, including tragedy where it was one of several important anachronistic political ideas. The demonization of the tyrant also led to the development of tropes to create the stereotype of the tyrant. These tropes are catalogued in Plato and Aristotle and widely recognised in Herodotus, but as Lanza (1977) and Seaford (2003) have pointed out, they also occur in tragedy, to the same extent as they do in prose. The tropes can roughly be split into two groups - those that are based on real powerconserving strategies and those that were created to characterise the tyrant as a moral monster.
\end{abstract}




\section{Acknowledgements:}

This thesis was by no means easy to produce and I could never have done it without much help. Therefore, I would like to thank a number of people.

Firstly, I would like to thank Dr James Kierstead, my supervisor, for giving valuable advice and feedback on my thesis, helping me formulate my ideas into coherent theories and steering me towards useful papers and books and away from dated research.

I would also like to thank the Classics department in general, especially Dr Simon Perris for letting me bounce some ideas in my thesis off him and giving a rather useful talk on the subject of oligarchy in tragedy, Dr Judy Deuling, for looking out for me, and Nikki MacDonald and my office-mates for putting up with my antics.

My biggest thanks as usual go to my parents who have again and again given me emotional support and encouragement, proofread my drafts, let me live with them all year round, done most of my chores and cooked dinner almost every night. I really couldn't have done it without you.

I would also like to acknowledge my brother Alexander, my friends Susan, Mira, Melissa and Hannah and especially my girlfriend Riza for providing emotional support and keeping me going through the high workload of Masters.

Thanks too to the cast of VATS' The Rope, for providing me with a thoroughly enjoyable excuse for taking longer to finish my thesis. 


\section{Contents:}

\section{Introduction (Page 5)}

Chapter One: Greek Tyranny: From Archaic Regime to Political Idea to Literary Trope (Page 10)

1.1. What was Archaic Tyranny? (Page 12)

1.2a. Causes of Archaic Tyranny: Intra-elite stasis (Page 14)

1.2b. Causes of Archaic Tyranny: Class stasis: socio-political conditions influential to tyranny (Page 15)

1.3. Archaic views on tyranny (Page 19)

1.4. Classical views on tyranny (Page 22)

Chapter Two: Political anachronisms of tyranny in tragedy (Page 26)

2.1. Political Anachronisms (Page 27)

2.2. Aeschylus (Persae) (Page 31)

2.3. Sophocles (Oedipus Tyrannus) (Page 32)

2.4. Euripides (Page 34)

Chapter Three: Tyrant Tropes in Tragedy (Page 45)

3.1. Types of tragic rulers (Page 46)

3.2. The tyrant tropes as seen in prose (Page 47)

3.3. Semi-tyrants (Page 52)

3.4. The tragic tyrants as individuals (Page 53)

3.5. Tyrant tropes (Page 55)

3.6. Good Kings (Page 83)

3.7. Other rulers (Page 88)

Conclusion (Page 90)

Appendix A: A Categorisation of Tyrant Tropes (Page 92)

Appendix B: The evolution of tyrant tropes in tragedy (Page 101)

Bibliography (page 103) 


\section{Introduction:}

The image of the tyrant as a cruel and oppressive ruler has been a pervasive one in western politics and literature since its inception in sixth century B.C.E. Greece. The continuity of this image across the centuries is striking and is the product of continuous adaption and repetition of ideas and tropes of tyranny. These tropes are the parts that make up the whole of the tyrant. In depictions of tyrants in the fourth century and later, these tropes are clear and easy to see, but in fifth century tragedy, as in Herodotus, they are more subtle and so present a unique challenge to scholarship in their identification, classification and relation to later versions of these tropes. This is not an area that has been excessively studied, especially in English - in which the main work is Seaford's 2003 article "Tragic Tyranny", ${ }^{1}$ while the most comprehensive work on the subject to date is Lanza's 1977 Il tiranno e il suo pubblico. ${ }^{2}$

However, tyranny did not start off as the idea that we know today; rather it evolved to this through the transition of Archaic Greece into democracy. Tyranny both as a topic and as a collection of character traits made its way from politics into literature, including tragedy. In particular, he antithesis between tyranny and democracy, central for Athenian politics, is commonly seen in tragedy. More significant is the existence of the stereotyped tyrant with a nearly complete (from the vantage point of fourth century and later authors) array of tyrannical traits. This phenomenon has been commented on by Lanza and Seaford, but I am hoping to categorise and emphasise these more heavily. This having been said, it is also important to emphasise that tragedy was not responsible for the formation of tyrant tropes but rather reflected the development of this trope in Athenian politics.

These points will be backed up by a discussion of the history of tyranny. But first, what is a tyrant? ${ }^{3}$ The Oxford English dictionary defines a tyrant as 'A cruel and oppressive ruler'. ${ }^{4}$ This definition goes back at least to Latin where tyrannus has a meaning synonymous with its modern descendent. Even the Greek tyrannos often meant something similar to what we think

\footnotetext{
${ }^{1}$ Seaford, R. (2003a). "Tragic Tyranny," in Morgan, K. A. (e.d.), Popular tyranny: sovereignty and its discontents in ancient Greece. Austin: University of Texas Press: 95-115

${ }^{2}$ Lanza, D. (1977). Il tiranno e il suo pubblico. Turin: Einaudi

${ }^{3}$ For the bulk of this thesis, the English words 'tyrant' and 'tyranny' will be used as synonyms of the Greek tyrannos and tyrannis respectively.

${ }^{4}$ Oxford Dictionaries. (2019). Tyrant. Oxford Living Dictionaries. Accessed Wednesday $28^{\text {th }}$ March, 2019, $<$ https://en.oxforddictionaries.com/definition/tyrant>
} 
of as a tyrant. However, in classical Greek the word tyrannos often has the meaning of 'ruler who gained power by his own means (as opposed to inheriting it) or simply 'king', a meaning that is much emphasised in tragedy. So, where did our concept of tyrant come from?

Tyranny, tyrannis, was in fact a type of Greek sole rule that came into existence in seventh century Greece, a regime that bore little resemblance to the later concept of tyranny that evolved from it. The rulers who we now call archaic tyrants were not actually divided by wealth, ruling style or hereditary nature of their rule from the basileis that preceded and coexisted with them. The rule of tyrannoi and basileis was based on the value of arete, excellence, which was determined by the ideal of archaic Greece. Tyranny was a normal part of archaic aristocratic politics.

The causes of tyranny are locked into the ideals and socio-political conditions of the archaic period. Tyranny emerged due to individuals making use of the stasis or civil strife which was common in archaic poleis. The cause of this stasis were the socio-political issues of class and intra-elite stasis. The invention of money created more inequality and debt in Greek society, as well as creating nouveaux riche individuals and a new middle class who wanted political rights. Likewise, the constant stasis between aristocrats competing in the atmosphere of competitive de facto power also caused instability in Archaic society. Whether or not prospective tyrants tried to please the people and solve these problems, these issues definitely had a role in the existence of tyranny.

Tyranny during this period was seen by the Archaic poets as a great blessing because of the power and wealth associated with it. ${ }^{5}$ This is the main view we see in Archilochus and even later authors like Alcaeus may have to be more motivated by personal jealousy of tyrants than by genuine dislike of tyranny as a regime. ${ }^{6}$ From a similar aristocratic attitude came the earlier ideas of tyranny as a negative result of stasis: tyranny was a bad thing as it involved taking the equal power (isokratia) away from the ruling elite. This was combined with the view seen in Solon that tyranny was bad for the polis and the emergence of support for more democratic governments of which tyranny was the antithesis. Thus, even in the sixth century, we see the beginnings of the later attitude to tyranny.

\footnotetext{
${ }^{5}$ Archilochus, fr. 23 West; Alcaeus, fr., 70

${ }^{6}$ Alcaeus, fr., 70.10-13
} 
The fifth century bought the emergence of democracy and with it a more negative view of tyranny. The idea of the tyrant as an antagonist to the equality of the citizens under democracy was imported from the aristocratic tradition. This was strengthened by a general shift in elite ideology from allegiance only to one's family to allegiance primarily to the democratic polis: civic mindedness became very important. ${ }^{7}$ This in turn led to the fifthcentury antithesis between democracy and tyranny, where tyranny was used as a foil to emphasise the benefits of democracy. The emergence of democracy, however, led to the rise of oligarchy, which being effectively a form of tyranny from the point of view of the people, was coalesced and confused with tyranny in democratic thought. While tyranny and barbarian kingship were viewed negatively, the idea of a good basileia (as opposed to a bad tyranny) did continue into the fifth century, albeit with a democratic flavour. As the fifth century became the fourth, the basileus, a good king whose regime was based on virtue not democracy, was now a model of good government.

Tyranny lost its relevance as a political and ideological concept in Athenian politics in the fourth century, but it continued to be used in literature and political philosophy. The literary tyrant was characterised by a combination of fifth century moral judgements on tyranny and actual tyrannical traits in Herodotus and fifth century tragedy. These traits were later catalogued by fourth century philosophers along with those of the good king. The literary tyrant became a key figure of declamatory Hellenistic oratory from which it was transferred to the Romans and to later western civilisation.

But to return to tyranny in tragedy. Except for Aeschylus' Persae and a few other lost plays, tragedy was set in the world of mythical, Homeric Greece. However, tragedy contained numerous anachronisms that were used to discuss contemporary political ideas. Firstly, the keystone upon which the portrayal of all fifth century politics was laid, the polis, was an important part of Greek tragedy, as was money, an element of Classical life and politics that had not existed in the time of Greek myth. These anachronisms facilitated the exploration of the conventional political idea of the antithesis between democracy and tyranny in tragedy. This often takes the form of a conflict, sometimes in an agon scene, between tyrannical and

\footnotetext{
${ }^{7}$ Anderson, G. J. (2005). "Before turannoi were tyrants: rethinking a chapter of early Greek history", Classical Antiquity. 24(2): 173-222: pp. 212-3
} 
democratic characters. It first appears in Aeschylus' Persae, next briefly in Sophocles' Oedipus Tyrannus, but it becomes more frequent and significant in Euripides - appearing in Euripides' Electra, Supplices, Heracleidae and Phoenissae.

The existence of the polis and anachronistic ideas related to it such as tyranny means that characters in tragedy can also be typed into political characters - most significantly the tragic tyrant, but also others like the "democratic king", a monarch who rules with in a democracy, and the "good king", a monarch who rules by his virtues. Not all kings who are portrayed negatively in tragedy are fully fleshed examples of tragic tyrants, however, because some do not exist in play with politics or the polis, but those that are can be catalogued by looking at the tyrants' features in Plato, Aristotle and Xenophon, where tyrants are characterised with illegitimate routes to power, violent power-conserving methods, depriving citizens of their rights, impiety, lack of self-control and greed. All of these tropes are seen in tragedy. The similarity between the tragic tyrant and the tyrants of the fourth century philosophers and Herodotus shows us that tragic tyrants are undoubtedly part of this tradition. The complete nature of the tragic tyrant as early as Aeschylus' Oresteia shows us that the stereotypical tyrant was not a product of tragedy and that the development of the trope was likely more influenced by the development of political ideas on tyranny than the development of the tragic tyrant. Nevertheless, the tyrant does develop over the course of Greek tragedy, until it almost reaches the form it takes in fourth century political philosophy.

It is also illuminating to look at the tyrant's ideological opposites. A form that is not seen anywhere else is the democratic king - a 'first citizen' style monarch, whose rule is characterised as good by its democratic nature as well as other good king traits. Theseus in Euripides' Supplices is the most prominent example of this, but Pelasgus of Argos in Aeschylus' Supplices and Theseus' son Demophoon in Heracleidae are also examples. The democratic king plays a larger role than the good king of who is characterised by his (nondemocracy related) arete- - his sense of justice, courage, piety, respect for xenia and philia and wisdom. However, the role of this character in later political discourse is so important that it is still worthwhile to look at Oedipus, this character's only example in tragedy.

The existence of the key fifth century ideological concept of the tyrant in tragedy is significant as part of a discussion of politics in Greek tragedy. Tyranny's enduring significance in Greek politics and thought began as sole rule gained notoriety with the rise of 
democracy and tyranny became a crucial political idea in the ideology of Athenian democracy. It is little wonder that Athenian tragedy explores this key political idea. Moreover, the widespread existence of tyrant characteristics seen in other Greco-Roman literature holds considerable academic interest, as does the categorisation and development of these tropes. 


\section{Chapter 1: Greek Tyranny: From Archaic Regime to Political Idea to Literary Trope:}

The Greek concept of tyrannis, 'tyranny', went through many permutations to arrive at the fifth century concept of the tyrant as an evil ruler. The tyrannos was initially a type of monarch who appeared in Greece in the seventh century B.C.E and continued to be a feature of the Greek poleis throughout the Archaic period, and to a lesser extent in later eras. The historical beginnings of the tyrant in Archaic Greece are key to understanding the later concept of tyranny, because it is from the historical figures of Archaic and Classical tyrants and the rise of democratic ideology that the literary and political tyrant was formed.

Modern scholarship has theorised at length about the nature of archaic tyranny. The latest and most convincing view considers tyranny a normal part of archaic politics and a type of basileia - as opposed to a separate phenomenon as has previously been assumed. ${ }^{8}$ The evidence of this is seen in the shared value of arete as the ideological basis of power in tyranny and basileia (as well as aristocratic archaic Greek society in general). The etymological evidence of the word 'tyrannos' as a synonym for basileus or a neutral word for a self-made ruler also confirms this. ${ }^{9}$ I will argue that there is little evidence that the tyrants engaged in oppressive behaviours attributed to their fictional relations; however, the tyrants' populism was probably not an anachronistic fifth century invention and it is clear that the tyrants did introduce popular policies.

The tradition is equally divided on the causes of tyranny, but here I will argue that tyranny was caused by stasis,${ }^{10}$ civil war or factionalism, caused in turn by the socio-political climate of Archaic Greece. Archaic Greece was ruled by narrow oligarchies in which de-facto power was more significant than official office. ${ }^{11}$ This led to intra-elite stasis as members of the aristocracy tried to secure power. Moreover, the recent invention of money (combined with increasing trade) led to widespread inequality and debt, as well as the disenfranchisement of the new rich and middle classes, led to class stasis between different social groups. The intraelite and class stasis created a situation in which an aristocrat with sufficient ambition, philotimia, could put himself in charge of a city. The invention of hoplite warfare, however, probably did not play a part in the rise of tyranny because of its gradual nature.

\footnotetext{
${ }^{8}$ Morris J. (1996). "The strong principle of democracy", in Ober, J. and C. Hedrick, ed., Demokratia: A Conversation on Democracies, Ancient and Modern. Princeton: Princeton University Press; Anderson 2005 9 Andrewes, 22-23; Parker, V. (1998). "Tú $\alpha$ avvos. The semantics of a political concept from Archilochus to Aristotle," Hermes. 145-172: pp. 147-153

${ }^{10}$ C.f. LSJ, $\sigma \tau \alpha \dot{\sigma l \varsigma, ~ ' I I I . ~ E s p . ~ p a r t y ~ f o r m e d ~ f o r ~ s e d i t i o u s ~ p u r p o s e s, ~ f a c t i o n . . .2 . ~ F a c t i o n, ~ s e d i t i o n, ~ d i s c o r d ' . ~}$

${ }^{11}$ Anderson, 2005, 180
} 
From its inception and throughout the archaic period, tyranny was, for the most part, viewed favourably and the tyrant was looked upon as fortunate because of his great power and wealth. However, negative views of tyrants appeared as early as Theognis. Some of these were to do with personal jealousy, but the main objections to tyranny were that it broke down the isokratia held by the aristocracy and the stasis that the quest for it caused. These latter reasons would become the basis for anti-tyrannical attitudes of the classical period.

The rise of democracy brought with it a more decisive change in views on tyranny. The widening of the aristocratic ideals of isokratia and isonomia to include the entire citizen body of the polis meant that the freedom of all citizens was threatened by the rule of a tyrant. Moreover, the tyrant and the archaic aristocratic ideal of individual glory that he represented was the anathema of the civic minded polis, in which elites (and others) were expected to gain fame through their commitment to the city, not their own personal achievements. These changes in attitude were combined with the behaviour of classical tyrants who could no longer rely on a popular support from newly democratic poleis with fixed constitutions and had to resort to establishing their own unique type of power which was more oppressive than that of their archaic forebears.

This led to tyranny and democracy being ideologically opposed in the fifth century, with tyranny becoming the foil that showed up democracy's benefits. The tyrant became the bogeyman of the democratic polis and a slur that could be applied to whoever the citizens considered their enemies. In addition, oligarchy, the real danger to democracy in Classical Athens, was vilified by association and conflation with tyranny. It was in the fifth century that the literary tyrant first came into existence, already with most of his later features. The appearance of a complete tyrant figure, as opposed to a gradual development, shows us the level of characterisation that had already gone into this ideological bogeyman in political rhetoric. The defeat in the Peloponnesian War and the episode of the Thirty Tyrants changed the Athenian political climate, making the tyranny/democracy contrast politically irrelevant. The tyranny/democracy contrast was replaced by that of the tyranny/good king contrast and the tyrant was codified into a series of tropes. 


\subsection{What was archaic tyranny?}

There are two prevailing theories on the nature of tyranny. Firstly, the conventional, that tyranny was a novel form of sole rule, based upon popular support and the socio-political conditions of the archaic period, and that tyranny acted as a transitory regime between archaic oligarchy and classical democracy. ${ }^{12}$ The second, more recent, calls into question archaic tyranny as a separate phenomenon, instead suggesting tyranny as a normal part of archaic politics and the tyrant as an orthodox ruler in the tradition of Greek basileia, with the concept of tyranny as a unique phenomenon being the product of later thinking. ${ }^{13}$

The second, more modern view has the most validity. Firstly, the concept of tyranny as a distinct regime type needs to be discussed. Mitchell believes this idea goes back at least to Thucydides, when Thucydides asserts that the tyrants were wealthy rulers who ruled unconstitutionally whereas kings ruled by ancestral rule. ${ }^{14}$ Mitchell argues that in reality, tyrants had as much claim to ancestral rule as the Bronze Age and Dark Ages basileis since ancestral rule was usually based on descent to a founder just outside living memory and attempts to trace one's ancestry to heroic forebears (which also occurred in tyrannies). ${ }^{15}$ Likewise, wealth was a prerequisite for any form of sole rule, though the importance of the ruler using his wealth for the betterment of the community instead of himself became more important during the archaic period, and tyrants, contrary to the stereotypes, spent their money on the polis. ${ }^{16}$ Similarly, Mitchell argues that the tyrants, like other Greek rulers, were not unconstitutional or absolute rulers because absolute rule is a later invention and the Greek rulers needed to rule in accordance with other polis institutions like assemblies and councils in order to stay in power. ${ }^{17}$ There is also the evidence that tyrannos and its compounds were, in Herodotus and for the most part in the tragedians, used interchangeably with basileus, to mean 'king', which gives further evidence for Mitchell's view. ${ }^{18}$

\footnotetext{
${ }^{12}$ C.f. Andrewes, A. (1963). The Greek Tyrants. New York: Harper \& Row; Hegyi, D. (1965). "Notes on the origin of Greek tyrannis," Acta Antiqua, 13: 303-318; Drews, R. (1972). "The first tyrants in Greece," Historia: Zeitschrift für Alte Geschichte. (H. 2): 129-144; Fleck, R.K., and Hanssen, F. A. (2013). "How Tyranny Paved the Way to Democracy: The Democratic Transition in Ancient Greece," Journal of Law and Economics, 56: 389-416.

${ }^{13}$ C.f. for example, Mitchell, L. (2013). The heroic rulers of Archaic and Classical Greece. London and New York: Bloomsbury Academic. The tyrant as a king is mentioned by Andrewes and Hegyi, 1965, 306, and Parker, 1998, 170-1.

${ }^{14}$ Thuc. 1.13.1; Mitchell, 2013, 34, 41

${ }^{15}$ Mitchell, 2013, 36-40

${ }^{16}$ Mitchell, 2013, 42-44: Of the tyrants, Periander, Gelon and Pittacus were particularly known for restraint in private spending.

${ }^{17}$ Mitchell, 2013, 126-7; 131-2; 142

${ }^{18}$ Parker, 1995, 145; 169 etc.
} 
Therefore, in discussing the reality of archaic Greek tyranny we should actually be discussing the reality of Greek basileia, of which archaic tyranny is an example. Greek basileia, or kingship, was based on arete, virtue, by which a ruler or prospective ruler displayed their right to rule. Arete was displayed through the ability to conform to archaic aristocratic ideals ${ }^{19}$ through martial prowess, victories in Pan-Hellenic festivals, habrosynē ('luxury'), megaloprepeia ('magnificence') in offerings, orientalising style and connections to the divine (such as cultivating hero cult and claiming descent from heroes). ${ }^{20}$ These were the values cultivated by basileis and also the aristocracy at large — showing us that both Anderson's theory that the tyrants were part of the aristocracy and also Mitchell's one of the tyrants as basileis are valid.

The tyrants' policy did not differentiate much from the aristocratic ones - they kept the same constitutions and official workings of state. ${ }^{21}$ These points disprove the idea of tyranny as a transitory regime that bought the Greek poleis from aristocracy to democracy. ${ }^{22}$ This is usually based upon the idea that tyranny gave the demos greater political consciousness and fostered civic consciousness within the polis, ${ }^{23}$ as well as an expectation for the populist policies that the tyrants used. ${ }^{24}$

This, however, brings us to the next big issue of archaic tyranny. How popular were the tyrants' regimes? The stories of Peisistratus and Cypselus in Herodotus support the view that the tyrants were popular (if not populist), and should not entirely be dismissed as fictions invented to confirm fifth century ideas of tyrants as demagogues. ${ }^{25}$ The existence of these mythological stories about the tyrants is possibly the strongest indicator for their popularity, as these stories only spring up around figures who are viewed favourably. ${ }^{26}$ It is also quite likely that the demos, for example with Pittacus in Mytilene, were grateful to the tyrants for freeing their cities from constant stasis. ${ }^{27}$ Andrewes believes that the 'New-Deal' style public

\footnotetext{
${ }^{19}$ What Morris calls the 'elitist tradition'. C.f. Morris, 1996, 31-4.

${ }^{20}$ Morris, 1996, 22-3; Mitchell, 2013, 60-80; Anderson, 2005, 183-8

${ }^{21}$ For example, the fragmentary archons list that we have from the Peisistratids show several prominent members of other important Athenian families (e.g. Cleisthenes of the Alcmaeonidae) holding the eponymous archonship (Andrewes, 1963, 80).

${ }^{22}$ As proposed by Hegyi, 1965, 303-4 and Andrewes 1963.

${ }^{23}$ For example, saying that Peisistratus created the Pan-Athenian festival to foster civic unity (Anderson, 2005, 93-4).

${ }^{24}$ Hegyi, 1965, 313

${ }^{25}$ Hdt. 5.92. (Cypselus), Hdt. 1.59 (Peisistratus); Andrewes, 1963, 43-48; McGlew, J. F. (1996). Tyranny and political culture in ancient Greece. Ithaca and London: Cornell University Press, pp. 71-2

${ }^{26}$ Andrewes, 1963, 43-8, esp. 46

${ }^{27}$ Andrewes, 1963, 60
} 
works building programmes, which Peisistratus and the Cypselids engaged in, ${ }^{28}$ were a full employment policy. ${ }^{29}$ Peisistratus' loans for small farmers, ${ }^{30}$ institution of travelling judges and tours of inspections are other examples. ${ }^{31}$ Other evidence of popularity includes several tyrants' reputations for obeying the laws. ${ }^{32}$ Moreover, the Peisistratidae were thrown out by the Spartans, not by the people and had no particular desire to help with several attempts by the Alcmaeonidae to return Athens to aristocratic rule. ${ }^{33}$

Perhaps the most convincing evidence of the tyrant's popularity is the word tyrannos itself; even its Latin derivative could be used in poetry as a neutral word for 'king' and for a long time tyrannos could mean simply a self-made ruler without any opprobrium: in Thucydides the tyrannos is described as a self-made ruler whose power is not limited by constitutional checks. $^{34}$

\section{2a. Causes of Archaic Tyranny: Intra-elite stasis:}

The archaic poleis existed in a constant state of stasis. ${ }^{35}$ This, along with philotimia, ambition, was one of the direct causes of archaic tyranny. Stasis allowed ambitious aristocrats to seize power and become tyrants. It was also often caused by the aristocrats themselves.

There were several factors responsible for intra-elite stasis. Firstly, power in the archaic polis was mostly de-facto as official positions did not have much power attached to them. ${ }^{36}$ Secondly, the aristocratic Archaic culture was very much one of competition, as individuals and families showed off their wealth and power in Panhellenic games and through their commitment to the ideals of megaloprepeia ("magnificence") and habrosyne ("luxury") and connections with the divine. ${ }^{37}$ This culture was heavily influenced by the East, where powerful monarchs, the first tyrannoi, reigned with unimaginable wealth and luxury. ${ }^{38}$ Thirdly, the political and economic climate was changing in the seventh and early sixth

\footnotetext{
${ }^{28}$ Andrewes, 1963, 111

${ }^{29}$ Andrewes, 1963, 51

${ }^{30}$ Andrewes, 1963, 111

31 Andrewes, 1963, 111

${ }^{32}$ For example, Andrewes believed Peisistratus was the model for the good 'half-wicked' tyrant in Aristotle's

Politics (Andrewes, 1963, 109).

${ }^{33}$ Andrewes, 1963, 108

34 Thuc., 1.13.1

35 Anderson, 2005, 181; Andrewes, 1963, 96-99; Forsdyke, S. (2009). "The uses and abuses of tyranny", in

Balot., R.K. (ed.), A companion to Greek and. Roman political thought. Oxford: Wiley-Blackwell: 231-246

${ }^{36}$ Anderson, 2005, 181

${ }^{37}$ Anderson, 2005, 183-5

38 Anderson, 2005, 184
} 
centuries, dividing the aristocracy between old and new forms of wielding power. ${ }^{39}$ These factors led to a constant struggle for de-facto power between the aristocrats, in which the elites spent their time fighting each other with their private armies.

McGlew and Forsdyke point out that there is plenty of evidence in elite archaic poetry that tyrants were thought to arise from elite stasis: Solon and Theognis considered that stasis could be solved by the ascension of the most powerful faction leader to the tyranny - the tyrant is portrayed as the punisher of elite stasis, who punishes the polis with the rule of the most hubristic faction leader, whose rule could have been avoided if the elite only ruled well (and avoided stasis). ${ }^{40}$ A similar situation happened in Athens with Solon, who, though the stasis that directly caused his appointment was class based, blamed elite squabbling for the problems Athens was facing at the time. ${ }^{41}$ Apart from Solon, there is also ample evidence for intra-elite stasis leading to tyranny at Alcaeus' Mytilene. A series of ambitious men (Melanchrus, Myrsilus, and finally Pittacus) became tyrants. ${ }^{42}$ The stasis within the elites and between the elites and the tyrants was so serious that the citizens of Mytilene elected Pittacus as tyrant to stop the exiled aristocrats from returning home and causing more stasis. ${ }^{43}$

Pittacus, by suppressing this factionalism, finally gave Mytilene peace, and was able to resign with this peace continuing. ${ }^{44}$

\section{2b. Causes of Archaic tyranny: Class stasis: socio-political conditions influential to tyranny}

Some scholars, most notably Anderson, believe that class stasis had little effect on tyranny. However, even Anderson agrees that the existence of class issues made it easier for ambitious men to take power. It is likely that the role of populism and class issues in the rise of tyrants is exaggerated in ancient sources and some modern scholarship, yet still existed. ${ }^{45}$ Simonton points out that popular support (and populist policies) did play a part in the rise and regimes

\footnotetext{
${ }^{39}$ Andrewes, 1963, 96

${ }^{40}$ Forsdyke, 2009, 234-5; McGlew, 1996, 72-4

${ }^{41}$ Andrewes, 1963, 85

42 Andrewes, 1963, 96

${ }^{43}$ Andrewes, 1963, 93-4; 98-9. Hence Aristotle categorises Pittacus as an elected tyrant, asymnetes.

${ }^{44}$ Andrewes, 1963, 98. Simonton believes that the people preferred tyrants because tyrants could act in their interests and control the elite (Simonton, M. (2017). Classical Greek Oligarchy: A Political History. Princeton: Princeton University Press: 20, note 80).

${ }^{45}$ Regarding modern scholarship, see Anderson 2005 and Andrewes 1963, who also cautions taking this view too far.
} 
of tyrants - the desire for a break from aristocratic stasis as described above, but also specifically class related issues. ${ }^{46}$ The evidence for this is in Solon-when Solon apologises for not taking up the tyranny, he cites execution of the rich and redistribution of their wealth as something that would be expected to happen under tyranny. ${ }^{47}$ From this, despite a potential degree of aristocratic bias, we can see that the average tyrannical policy was indeed populist. On the other hand, we can ignore Herodotus' statements that Peisistratus was a populist and made up the Plain party to champion the demos and seize tyrannical power. ${ }^{48}$

The importance of class and populism in the development of tyranny can be shown by looking at Solon's reforms. ${ }^{49}$ Solon was Athens' alternative to tyranny and thus, the situation in Athens was likely similar to that in other poleis who had tyrants. ${ }^{50}$ Solon's Athens, as well as other parts of Greece, was suffering from class issues. As in other areas of Greece, there were two major issues - firstly, widespread poverty and secondly, a disenfranchised middle class and nouveau riche.

These issues began in the seventh century, when Greece experienced a period of economic growth. The formation of colonies facilitated more overseas trade and silver coinage arrived in Greece. ${ }^{51}$ Before the invention of money in seventh century Lydia, the Greeks had used the barter system seen in Homer and Hesiod, followed by money's direct precursor, trade with weights of precious metal. ${ }^{52}$ Because money (unlike barter goods) is imperishable and storable in large quantities, it was possible to accumulate more wealth than previously. ${ }^{53}$ However, the reverse was also true, if the rich could store up unlimited wealth, so the poor could accumulate unlimited debt (and it was easier to borrow coinage).$^{54}$ This was exactly what happened when small farmers could not take advantage of trade which led to greater inequality. ${ }^{55}$ In Athens, these issues were made worse by a very harsh law on debt written by Dracon. ${ }^{56}$ Dracon might have also been responsible for the rise of the hektemoroi, small

\footnotetext{
46 Simonton, 2017, 24-30

${ }^{47}$ Solon, fr. 32 West

${ }^{48}$ See Andrewes, 1963, 103-5; Arist., Ath. Pol., 13-14; Hdt. 1.59

49 Andrewes, 1963, 87

${ }^{50}$ Andrewes, 1963, 37; 84

${ }^{51}$ Andrewes, 1963, 78

52 Andrewes, 1963, 78-79

53 Andrewes, 1963, 78-82

${ }^{54}$ Andrewes, 1963, 82

55 Andrewes, 1963, 81-2

${ }^{56}$ Andrewes, 1963, 84
} 
farmers who bought land from wealthy landowners and had to pay it back either with a $1 / 6$ (one hektemorion) of their produce or by enslaving themselves. ${ }^{57}$

The economic expansion also led to an increase in non-aristocratic wealthy individuals and the middle class, who wanted a say in the government and political power. In the archaic period, political power and office was only held by the aristocracy, which was often a small circles of families (e.g. the Bacchiadae at Corinth or the Penthilidae at Mytilene) or only by some members of noble families (i.e. sons could not participate if their father was alive or younger brothers could not participate), with the rest of the population only being able to participate in the relatively powerless assembly. ${ }^{58}$

These socio-political issues were causing class stasis in Solonian Athens, so much so that many Athenians were sold into slavery. ${ }^{59}$ This, combined with the agrarian issues and intraelite stasis, was threatening Athens with tyranny. Solon (and so presumably actual tyrannoi) solved this cause of stasis by cancelling all the debts, by making it illegal to take someone as a slave in repayment of a debt and by buying back Athenians who had been sold into slavery in this way. ${ }^{60}$ Presumably this departed somewhat from the usual tyrannical 'reforms': the demos was not happy with Solon's reforms because he had not disposed violently of the aristoi and then distributed their wealth to his supporters. ${ }^{61}$

Solon also took measures to prevent a tyranny that pleased the nouveaux riches and middle classes. Solon divided the Athenian property classes along lines of wealth into four classesthe pentacosiomedimni, the hippeis, the zeugitai and the thetes. ${ }^{62}$ Of these, he gave major political office to the top two property classes. ${ }^{63}$ Minor office and membership of the probouletic council were also given to the zeugitai.${ }^{64}$ His reforms also benefited the poor as the thetes gained the vote in the Assembly and membership of the judicial courts, which were very important because many of Solon's laws were ambiguous and needed to go through the courts where the people had the power. ${ }^{65}$ This system worked relatively well, although there were a few issues to begin with, for example there were two years without an archon

\footnotetext{
57 Andrewes, 1963, 85-6

58 Andrewes, 1963, 1-12

59 Andrewes, 1963, 86

${ }^{60}$ Andrewes, 1963, 86

${ }^{61}$ Andrewes, 1963, 89-90

62 Andrewes, 1963, 86

${ }^{63}$ Andrewes, 1963, 86-87

${ }^{64}$ Andrewes, 1963, 88

65 Andrewes, 1963, 88
} 
(anarchiai) and Damasias held his archonship illegally for two years. ${ }^{66}$ By pleasing the wealthy commoners, Solon did not need to please the lower classes with the traditional spoils of the tyrant's followers - distributed confiscated property and dead aristocrats - because the hoplites could not rebel without the wealthy commoners who were no longer interested in overthrowing the state they were now a part of. ${ }^{67}$ While we do not really know much about the situation in other poleis, Andrewes posits that, for example, the accession of Cypselus would allow the middle classes and wealthy non-Bacchiads into minor government roles previously filled by the Bacchiads and places on Cypselus' council. ${ }^{68}$ The fact that Aristotle says he had no need for a bodyguard (and so could rely on the army) is also potentially significant. ${ }^{69}$

The tyrants also further benefitted the middle classes by taking measures to improve the economy, as bad management of which on the part of the aristocratic governments was a cause for stasis. ${ }^{70}$ Andrewes believes that, at the time of Cypselus' revolution, the existence of the Bacchiadae and the fact that the large trading classes in Corinth had no say in government, was, in the opinion of the middle class and wealthy non-aristocrats, limiting the city's opportunities for development of trade. ${ }^{71}$ The Cypselids improved the trade of Corinth by planting a number of colonies. ${ }^{72}$ In Athens, Solon's restriction of citizenship to skilled workers encouraged an influx of craftsmen, including Corinthian potters, who when combined with the superior Attic clay, gave Athens a monopoly in pottery. ${ }^{73} \mathrm{He}$ also restricted agricultural exports to oil only, stimulating the oil trade and keeping Athenian corn in Athens. ${ }^{74}$

\section{Discounted theories:}

I will briefly discuss two discounted theories on causes for archaic tyranny: the hoplite revolution and racial stasis. The 'hoplite revolution' is Nilsson's idea that the seventh century the replacement of the aristocratic individualised style of fighting seen in Homer with hoplite fighting including more of the people caused the middle class to demand political rights now

\footnotetext{
${ }^{66}$ Andrewes, 1963, 88

${ }^{67}$ Andrewes, 1963, 89

68 Andrewes, 1963, 49

${ }^{69}$ Andrewes, 1963, 36

70 Andrewes, 1963, 49-50 (Cypselids); 112 (Peisistratidae)

${ }^{71}$ Andrewes, 1963, 49

72 Andrewes, 1963, 49-40

73 Andrewes, 1963, 86

${ }^{74}$ Andrewes, 1963, 86
} 
that they too had to fight. ${ }^{75}$ But as they were as yet too politically immature as a body to rule by themselves, they set up a champion as tyrant. ${ }^{76}$ However, this theory began to fall out of favour after Andrewes and has been discounted by Simonton, who believes that this would not have happened as the Hoplite constitution was not something the Greeks recognised and when something like it did happen in the revolution of 411, it was considered very odd. ${ }^{77} \mathrm{He}$ also points out that the development of hoplite warfare was gradual and that the demos did participate in the Homeric army. ${ }^{78}$ Andrewes, as well as Heygi, ${ }^{79}$ believed that racial tension was a factor in archaic tyranny. ${ }^{80}$ This is the theory that the Dorians in the Peloponnesus ruled over groups of disenfranchised pre-Dorians whom their ancestors had conquered and that in Ionia, the Ionians ruled over the conquered Anatolians and the conquered populations were second class citizens. ${ }^{81}$ Andrewes does not really have any good examples on this, admitting he had only one example where this actually happened and the evidence is rather poor. ${ }^{82}$ As these ideas do not stand up to the rigor of modern analysis, we should instead look at tyranny as the product of intra-elite and class stasis, as well as the continuing aristocratic quest for arete.

\subsection{Archaic views on tyranny:}

At its inception, the concept of tyrannis carried connotations of great wealth, power and fortune with a hint of Eastern luxury and was consequentially greatly sought after. ${ }^{83}$ The first use of tyrannis in writing was by Archilochus in a poem describing the Lydian ruler Gyges: ${ }^{84}$

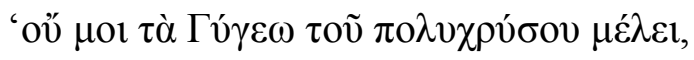

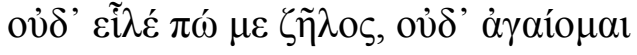

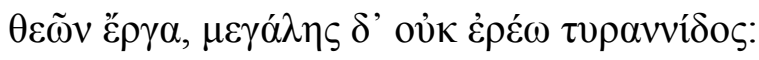

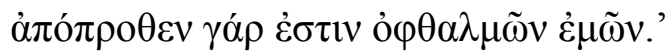

\footnotetext{
${ }^{75}$ Andrewes, 1963, 34; 51; Drews, 1972, 130; Nilsson, M. P. (1929). "Die Hoplitentaktik und das Staatswesen". Klio, 22(22), 240-249.

${ }^{76}$ Andrewes, 1963, 42

${ }^{77}$ Simonton, 2017, 26-28

${ }^{78}$ Simonton, 2017, 26-28

${ }^{79}$ Hegyi, 1965, 312

${ }^{80}$ Andrewes, 1963, 56-65

${ }^{81}$ Andrewes, 1963, 57-8

${ }^{82}$ Andrewes, 1963, 65

${ }^{83}$ Andrewes, 1963, 22; Parker, 1998, 151

${ }^{84}$ Andrewes, 1963, 21-2; Parker, 1998, 150-151
} 
'I do not care about the possessions of Gyges rich in gold,

Nor does jealousy strike me anywhere,

Nor do I envy the deeds of the gods,

And I do not wish to be a great king:

For these things are far away from my eyes. ${ }^{, 85}$

The tyrant is also seen as a wealthy and fortunate individual in Semonides' satire on women, later in the seventh century, where the tyrant, along with the skeptrophoros, a Homeric word for legitimate king, is seen as someone who could afford to keep the 'mare', the woman who is beautiful but useless. ${ }^{86}$

Alcaeus' poems show the same envy of the tyrant's prosperity, for which they have often been considered evidence of the existence of negative views of tyrants. ${ }^{87}$ On the other hand, Anderson suggested that Alcaeus was expressing his envy at the increased power and social standing that his rival Pittacus gained with his ascension to the tyranny, ${ }^{88}$ when he calls the

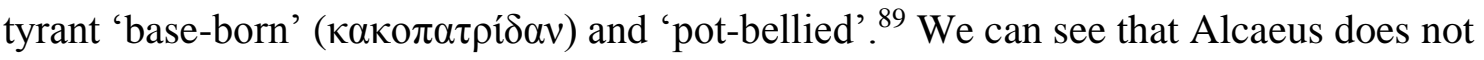
object to tyranny in and of itself when, as Anderson points out, he describes Pittacus' position as 'delightful glory': 90

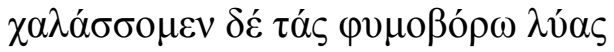

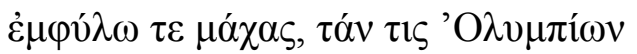

\footnotetext{
${ }^{85}$ Anderson, 2005, 204; Parker, 1998, 150-2

Another example is Fragment 23, in which Archilochus exhorts a friend to make himself tyrant of a captured city:

$\pi \hat{\lambda} \lambda] v \delta \dot{\varepsilon} \tau \alpha u ́ \eta[v \ldots[\ldots . . . \dot{\varepsilon}] \pi 1 \sigma \tau \rho \varepsilon ́[\varphi \varepsilon \alpha] \imath$

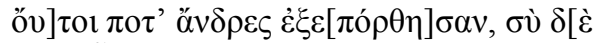

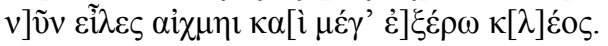

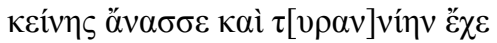

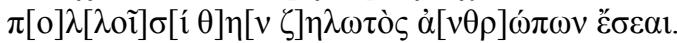

But this city...you turn about in

No men had ever sacked it, but you

Took it with your spear and great glory fell upon you.

Be the lord of it and hold its tyranny

Surely now you will be envied by many men (Archilochus, fr. 23 West)

${ }^{86}$ Semonides 7.67-70, Parker, 1998, 152-3

${ }^{87}$ Parker, 1998, 156-7: 'Nonetheless, Alcaeus' use of the word $\tau$ v́pavvo $\varsigma$ as a term of reproach against Pittacus emerges with perfect clarity: the word has taken on a negative colouring' (Parker, 1998, 157).

${ }^{88}$ Forsdyke, 2009, 237; Parker, 1998, 156-7,

${ }^{89}$ Alcaeus, fr. 348; Anderson, 2005, 205; Parker, 1998, 156-7

${ }^{90}$ Anderson, 2005, 205
} 


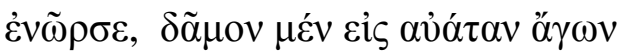

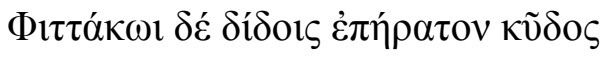

'And let us lay off heart-rending faction and civil conflict, which some

Olympian aroused, leading the people to ruin, but giving

delightful glory to Pittacus.' (Alcaeus, fr. 70.10-13).

Even in the archaic period, however, true negative ideas about tyranny were beginning to be formulated. ${ }^{91}$ First Solon, ${ }^{92}$ then Theognis and Alcaeus portray the tyrant as the punisher of elite stasis and the antithesis of good government (eunomia), good government being considered aristocrats ruling fairly, under the ideology of isonomia. ${ }^{93}$ Under this way of thinking, the tyrant is an usurper, whose seizure of power is bad for himself and the community. ${ }^{94}$

\section{The shift in attitudes:}

The rise of democr acy bought with it a decided cultural shift which affected ideas about tyranny. ${ }^{95}$ Firstly, the aristocratic ideals of isonomia, 'equality', and isokratia, 'equal power', as well as the right to vote, were extended to the entire citizen populace at the advent of democracy, which meant that all citizens had rights and freedoms that the tyrant could take away. ${ }^{96}$ A democratic citizen's political rights became synonymous with his eleutheria,

\footnotetext{
${ }^{91}$ Mitchell, 2013, 23

${ }^{92}$ Solon makes it clear that most people still believe that tyranny is greatly desirable, when he quotes the words of an imaginary opponent:

95 The transition between aristocracy and democracy is not to be confused with the transition proposed by Hegyi, Andrewes etc. from aristocracy to tyranny to democracy.

${ }^{96}$ Raaflaub, K. (2003). "Stick and glue: the function of tyranny in fifth-century Athenian democracy", in Morgan, K. A., Popular tyranny: sovereignty and its discontents in ancient Greece. Austin: University of Texas Press: p. 62
} 
'freedom', which he would now lose along with his political agency. ${ }^{97}$ This was strengthened by the fact that, even in the archaic periods, aristocrats like Alcaeus and Solon had been claiming that the tyrants were bad for the entire polis, not only themselves. The tyrant was also seen as a potential destroyer of the polis' constitutions, which again were a new, though not necessarily democratic, element of the classical polis. ${ }^{98}$

With the advent of democracy, the system of archaic aristocratic values came to an end. The elite ideals of habrosyne, megaloprepeia and divine connections was destroyed with the collapse of Eastern tyranny-the East's luxury was seen as a source of weakness after the Persian defeat in the Persian Wars, and even before that, with the defeat of Lydia. ${ }^{99}$ Morris' 'middling tradition', the proto-democratic ideology of essential equality between citizens, replaced this elite ideology. ${ }^{100}$ The most important thing was no longer heroic status, but citizenship and the benefits that came from this. The ideal man conformed to the ideology of to meson, "the middle", in which neither the poor nor the extremely rich had a place and received honour from his service to the polis. ${ }^{101}$ Aristocratic ostentation was no longer welcome and the ability of the heroic persona to secure rule declined, leading to the downfall and vilification of aristocratic government and tyranno $i$ which were essentially a part of it. ${ }^{102}$

\subsection{Classical views on tyranny:}

Regardless of how it came about, the image of tyranny as evil was a useful on for promoting democracy. Initially the antithesis was between democracy and both tyranny and barbarian kingship (though it seems likely that tyranny was seen as the worst form of sole rule as early as Aegisthus' Oresteia). This is prominently seen in Otanes' speech in Herodotus' Constitutional Debate, ${ }^{103}$ and Theseus' agon speech in Euripides' Supplices, in which tyrannos is used alongside other more neutral words for ruler, like basileus and monarchos. ${ }^{104}$ We can also see this where tyrannos and its compounds are used

\footnotetext{
${ }^{97}$ Anderson, 2005, 213

98 Anderson, 2005, 213

${ }^{99}$ Morris, 1996, 32-4, 38-40; Anderson, 2005, 211-2

100 Morris, 1996, 38-40

${ }^{101}$ Morris, 1996, 22-3

102 Morris, 1996, 38-40

103 Hdt., 3.80.2-6

${ }^{104}$ Eur., Supp., 426-462. These passages will be discussed in detail in Chapter Two.
} 
interchangeably for rulers in Herodotus and the same tropes that are applied to Greek tyrants are used for Eastern kings. ${ }^{105}$

Tyranny also played a role in the more realistic conflict between oligarchy and democracy in fifth century Athens. It was considered a common evil by both oligarchic and democratic factions. ${ }^{106}$ Though oligarchy was the most realistic threat to the democratic polis at the time, the spectre of tyranny allowed both the democrats and the oligarchs to have a common purpose. ${ }^{107}$ The danger of tyranny was continually emphasised in state ideology-most notably the glorification of the tyrannicides Harmodius and Aristogeiton and the oaths that Athenians were made to swear to kill tyrants, but also figures like Theseus the democratic king and tyranny's increasing importance in the agora. ${ }^{108}$

In Athenian domestic politics, the tyrant/democracy antithesis only became more crystallised as time went on. It was used heavily to discredit political opponents, especially by demagogues, by accusing them of aiming at tyranny, but also by the oligarchs who accused the people of being the demos tyrannos. Good examples of this are seen in Aristophanes' plays where he mocks the constant accusations of tyranny used in the political sphere and Cratinus' accusations that Pericles is aiming for tyranny. ${ }^{109}$

In Athens, oligarchy was deliberately confused with tyranny to reduce the legitimacy of it as a regime. Oligarchy was considered equal to tyranny because it took away the political freedom of the people like tyranny. Near the end of the fifth century, some oligarchs were, however, beginning to argue that tyranny was not in fact as immoral as democratic (and older oligarchic) rhetoric made it out to be; this type of thinking went out of fashion with the behaviour of the Thirty Tyrants, as Dodds points out. ${ }^{110}$ These ideas (especially the democracy/tyranny antithesis) made their way into literature, including tragedy and Aristophanes.

\footnotetext{
105 See Dewald, C. (2003). "Form and Content: The question of tyranny in Herodotus", in Morgan, K. A. (ed.), Popular tyranny: sovereignty and its discontents in ancient Greece. Austin: University of Texas Press: 25-58. ${ }^{106}$ Cerri, G. (1982). "Antigone, Creonte e l'idea della tirannide nell'Atene del V secolo (Alcune tesi di V. Di Benedetto)," Quaderni Urbinati di Cultura Classica, 10: 137-155: p. 142

${ }^{107}$ Forsdyke, 2009, 237

${ }^{108}$ Raaflaub, 2003, 62-69

${ }^{109}$ Aristoph. Wasps, 417 and especially 488-502; Aristoph. Thes., 338-9; Cerri, 1982, 142

${ }^{110}$ Dodds, E. R. (1961). Plato, Gorgias. A revised text with Introduction and Commentary. Oxford: Clarendon Press: p. 15
} 
The end of the Peloponnesian War bought an end to the importance of the democracy/tyranny dichotomy, as more moderate democracy came into favour. ${ }^{111}$ This, combined with the rise of Macedon, which was ruled by a king, rejuvenated the figure of the good king. ${ }^{112}$ The idea of a good king had not died during the fifth century but existed alongside the democracy/tyranny antithesis. One particularly fifth century incarnation of it in tragedy was the democratic king (first seen in Aeschylus' Supplices), a constitutional monarch and first citizen who presided over a democratic polis. The 'good king' was codified into a figure, who though still based on aretē, had a strong moral component. The revived ideal was most famously given form as Plato's philosopher kings, ${ }^{113}$ but it is also seen in Xenophon, ${ }^{114}$ Aristotle, ${ }^{115}$ and Isocrates. ${ }^{116}$

The good king was contrasted with a strengthened version of the tyrant, who was now somewhat of a bogeyman, having no relevance in contemporary politics, who indulged in acts of wickedness unrelated to conserving his tyranny. This was strengthened by a concerted effort by philosophers to disprove the still popular idea of the tyrant as the most fortunate of men by portraying the tyrant as miserable because of the crimes he is forced to commit to keep his power. ${ }^{117}$ It is no coincidence with this codification of rulers, Thucydides, at the end of the fifth century, came up with his famous definition of basileis as ancestral rulers with constitutional checks and tyrants as self-made rulers with unlimited power, and was the first author to consistently apply these terms in the same way as we do now. ${ }^{118}$

\section{Conclusion:}

Tyranny was mostly likely an ordinary part of the archaic political landscape and a continuity of traditions of arete-based basileia in Archaic Greece. Periods of one-man rule were native to the stasis-ridden landscape of archaic Greece and did not represent a serious break in policy with the conventional aristocratic regimes. Tyrants were products of their political era- of the de-facto politics and power structures of the Archaic Period, of aristocratic

\footnotetext{
${ }^{111}$ Giorgini, G. (1993). La città e il tiranno: Il concetto di tirannide nella Grecia del VII-IV secolo aC. Milan: Giuffrè: p. 156

112 Giorgini, 1993, 156

113 Plato, Resp., $6.485 \mathrm{~d}-486 \mathrm{~d}$

Plato thought that philosophers would be the best rulers and gives a list of reasons why they would be so, believing that philosopher would lack interest in sensual pleasures, and that philosophy would allow them to not indulge in the typical tyrannical pitfalls such as greed, cowardice, boastfulness and savagery.

${ }^{114}$ Agesilaus in Agesilaus and sometimes Cyrus in the Cyropaedia

115 Arist., Pol., 5.9.1314a-1315b: A related idea was Aristotle's 'semi-wicked' tyrant, who conserves his tyranny by acting like a king.

${ }^{116}$ Isocrates' Ad Nicocles and Evagoras, which are what Forsdyke calls "On Kingship" treatises. See below, ch. 3.6 and Forsdyke, 2009, 241-2

117 C.f. especially Xenophon's Hiero and Plato's Gorgias.

118 Thuc., 1.13.1
} 
ideology and a changing economic landscape. Populism did play a part in the rise of tyranny, one that should neither be overemphasised nor dismissed. Tyranny was greatly sought after and looked upon favourably in the archaic period, but the rise of democracy meant that the tyrant was increasingly seen as a self-serving figure who deprived the citizens of their rights and freedoms. The decline of tyranny as a regime meant that tyranny was for the most part a piece of political ideology, but even this was informed by archaic and classical tyranny. Tyranny was of great use as a foil for democracy in the fifth century - to unify the citizens behind a common cause and as a tool by both the oligarchic and democratic parties to blacken rivals. The contrast between tyranny and democracy became the contrast between tyranny and monarchy with the decline of radical democracy and the rise of Macedon. Tyranny was also increasingly codified and became an important part of literature and philosophy. 


\section{Chapter Two: Political Anachronisms of Tyranny in Tragedy}

Anachronism is a device frequently and deliberately used by the Greek tragedians. ${ }^{119}$

Anachronisms from the political sphere, including conventional opinions about tyranny, were no exception.

Anachronism in fifth century Greek tragedy used to be treated as something which was caused by lack of interest or care of the tragedians in historical accuracy. ${ }^{120}$ However, the existence of anachronisms such as writing and voting in tragedy is more generally agreed upon in tragedy. ${ }^{121}$ However, scholars see less examples of overt political ideas in tragedy. ${ }^{122}$ The point of this chapter is to disprove these misconceptions.

In tragedy, a set of interconnected political anachronisms allow the discussion of contemporary political ideas. These are grouped around the archaic and classical political situation and so include concepts like the polis, money-and of course contemporary regime types such as democracy, oligarchy and, unsurprisingly, tyranny and associated ideas. The most significant of these ideas for this thesis, tyranny as evil, is amply discussed through the portrayal of tragic rulers as anachronistically stereotyped tyrants, which is the topic of chapter three.

The antithesis between democracy and tyranny is another anachronistic concept pervasive in tragedy and so makes for an interesting study of tyranny related anachronisms in Greek tragedy. ${ }^{123}$ The theme first appears in Aeschylus' Persae, where it is not an anachronism as the play is set during the Persian Wars not the heroic past. After this, the theme takes a common form of a conflict between democratic and tyrannical characters, often in the agon scenes. In this form, it appears briefly in agones between Oedipus and Tiresias and Oedipus and Creon in Sophocles' Oedipus Tyrannus, before being featured more heavily in Euripides. Euripides' plays contain several lesser important examples, such as the contrast between

\footnotetext{
${ }^{119}$ Easterling, P. (1985). "Anachronism in Greek tragedy," The Journal of Hellenic Studies. 105: 1-10: pp. 1-2 ${ }^{120}$ Easterling, 1985, 1, especially n. 2. For examples, see Ehrenberg, V. (1954). Sophocles and Pericles. Oxford: Blackwell: p. 15 f; Knox, B. M. (1966). Oedipus at Thebes. Oxford: Oxford University Press: p. 61 ${ }^{121}$ For example, Easterling, 1985, passim; West, M.L. (2013). Hellenica: Selected Papers on Greek Literature and Thought. Volume II: Lyric and Drama. Oxford: Oxford University Press: pp. 197-200; Bain, D. (1977). Actors and Audience: a study of asides and related conventions in Greek drama. Oxford: Oxford University Press: p. 209

${ }^{122}$ C.f. For example, Perris, S. (2017). "Is There a Polis in Euripides’ Medea?" Polis, the Journal for Ancient Greek Political Thought. 34(2): 318-335: pp. 318-320; P. Finglass. (2005). "Is There a Polis in Sophocles' Electra?", Phoenix, 59.3/4: 199-209: p. 208.

${ }^{123}$ There are other anachronistic ideological ideas in tragedy relating to tyranny that I have not included here for want of space. One example is the tyrant's ideological use of dike for which see McGlew 1996.
} 
Aegisthus and Electra's peasant husband in Electra, but also the most important thematic examples in tragedy - the agon between Theseus and the Theban Messenger in Supplices and the agon between Eteocles and Jocasta in Phoenissae.

One might ask at this point, "What is anachronism? What is its purpose in Greek tragedy?" Most Greek tragedy and all of our extant plays apart from Persae were set in the mythical heroic past, a phenomenon which Easterling explains by the continuing imaginative appeal of this setting. ${ }^{124}$ Setting plays in a comfortably distant time period also meant that political commentary would be easier, and a playwright would be less liable to be taken to court like the comic playwrights Aristophanes or Phrynicus. ${ }^{125}$ Anachronism in Greek tragedy, is not, as commonly believed, caused by carelessness on the part of the tragedian. Indeed, the Greeks were very careful about what they included and made sure not to put anything they considered too modern, such as books or drachmas, in their plays. ${ }^{126}$ Ancient interest in anachronism was a product of Hellenistic scholarship and even that was mainly concerned with trivial examples. ${ }^{127}$ Easterling posits that the purpose of anachronism in Greek tragedy was to shock the audience out of their complacency with familiar mythological tales and to make them think critically about aspects of contemporary life, especially politics. ${ }^{128}$

\subsection{Political Anachronisms:}

Not all of the anachronisms in tragedy are political, but many of them are. ${ }^{129}$ The polis, an institution that developed in the eighth and seventh centuries, is very commonly mentioned. The polis in tragedy is in most cases another power in the city in contrast to the ruling family or king, but in the more anachronistic examples, ${ }^{130}$ the polis is presented as the main political force, with the ruler portrayed as the polis' servant. ${ }^{131}$ Institutions of the polis such as the assembly and voting appear-however, as West and Easterling point out, a limited version of the assembly existed in Homer and in Archaic poleis, as shown, for example, by the Spartan Rhetra. ${ }^{132}$ Another, more ideological, example of how the polis can be integrated into tragedy

\footnotetext{
${ }^{124}$ Easterling, 1985, 2

${ }^{125}$ Easterling, 1985, 9

${ }^{126}$ Easterling, 1985, 1-2

${ }^{127}$ C.f. Easterling 1985, 7-8 for examples.

${ }^{128}$ Easterling, 1985, 9. Eteocles' highly anachronistic agon speech in Phoenissae (discussed below) is an especially good example of this.

${ }^{129}$ For example, c.f. Easterling, 1985, 3-6, on writing.

${ }^{130}$ For example, Antigone, Euripides' and Aeschylus' Supplices and Oedipus Tyrannus

${ }^{131}$ West, 2013, 199

132 West, 2013, 199
} 
is seen in Antigone, in which Creon, especially in his initial speech to the Chorus, ${ }^{133}$ and his agon speech to Haemon, voices many anachronistic ideas about behaviours of the ideal citizen, ${ }^{134}$ such as placing duty to the state over duty to family, ${ }^{135}$ obeying orders, and discipline in hoplite formations. ${ }^{136}$ The polis is highly significant as an anachronism because of its central place in Classical Greek society and its connection to other political anachronisms.

Democracy is seen as an anachronism too - a number of states in plays (such as in Aeschylus' Supplices and Eumenides and Euripides' Orestes) ${ }^{137}$ are shown as 'protodemocratic' through the institution of voting; this is the case particularly in Aeschylus' Supplices where the decision as to whether the Danaids should be given sanctuary is put to the vote. ${ }^{138}$ West argues that this is not as anachronistic as we might think because of Homeric leaders gaining consensus from their armies through assemblies and early democratic systems such as the Spartan Rhetra where the assembly voted on proposals. ${ }^{139}$ There are also evidence of other democratic institutions like debate in the assembly in Orestes and Heracleidae. ${ }^{140}$

Another key anachronism in tragedy is money, which was strongly connected with tyranny in theorising about the regime type. What is the connection? Seaford points out that as money is an abstract concept, it can be used to value anything, and therefore is. ${ }^{141}$ If everything can be valued in terms of money, then money can buy power, the greatest power, tyranny. Money pays for mercenaries and with mercenaries, one can make oneself tyrant. With money and the mercenaries that money buys, there is no need to cultivate the traditional bonds that give a man power or even prevent him from been thrown out of the community-money dispenses with the need for philia, xenia, justice or piety. ${ }^{142}$ The man with money (and therefore power)

\footnotetext{
${ }^{133}$ Soph., Ant., $162 \mathrm{ff}$.

${ }^{134}$ Soph., Ant., 639ff.

${ }^{135}$ Kierstead points out that this is polis-based and not inherently democratic, rhetoric. Kierstead, J. (2017).

"Democracy's Humility: A Reading of Sophocles' Antigone," Polis, the Journal for Ancient Greek Political Thought. 34(2): 288-305: p. 290.

${ }^{136}$ Andrewes, 1963, 34; Griffith, M. (1999). Antigone: Sophocles. Cambridge: Cambridge University Press: pp. 48-9: As briefly mentioned in chapter one, hoplite fighting was a post-Homeric fighting style.

${ }^{137}$ Easterling, 1985, 2-3

${ }^{138}$ Aesch., Supp., 365-9

${ }^{139}$ West, 2013, 199; Easterling, 1985, 2-3

${ }^{140}$ Easterling, 1985, 2-3; West, 2013, 197-9

Even precious metal as currency is tangentially relevant as it allows for anachronistic connections between wealth and tyranny and points about bribery (Seaford, 2003a, 96-9).

${ }^{141}$ Seaford, 2003a, 97

${ }^{142}$ Seaford, 2003a, 97
} 
can have anything or do anything he wants, including, if not especially, tyranny. This is referenced multiple times in tragedy, the most striking being a fragmentary passage of Sophocles: ${ }^{143}$

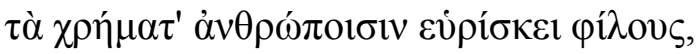

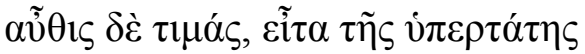

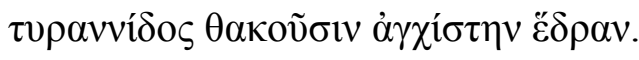

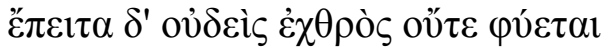

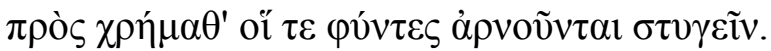

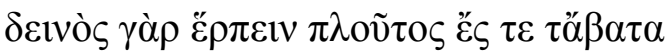

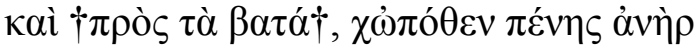

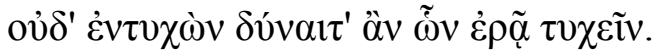

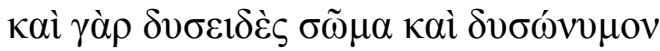

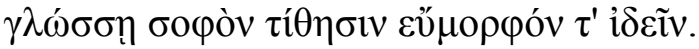

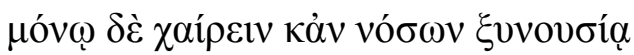

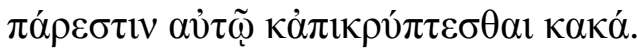

Money finds men friends,

And honours too, next it seats him upon

The highest seat of tyranny.

And then no one is an enemy to money

And those who are pretend to hate it.

For money is terribly good at getting to things both sacred

And profane, whence a poor man

Cannot hit upon that which he wants to find.

Moreover, money makes an ugly man seem handsome

${ }^{143}$ Seaford, 2003a, 98 
And a man hateful in tongue wise.

When he is sick, it allows him to rejoice in

The only cure and is bitter to evils. (Soph., fr. 88)

This phenomenon is also mentioned in the Oresteia, where Aegisthus tells the Chorus he

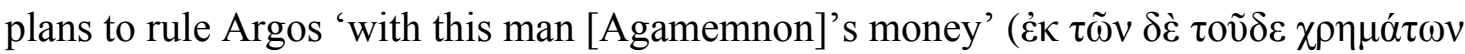
[Aesch., Ag., 1638)]).

Money is essential to tyranny because it pays for mercenaries. Oedipus elaborates in Oedipus Tyrannus when he asks Creon, whom he suspects of plotting against him:

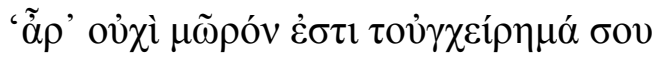

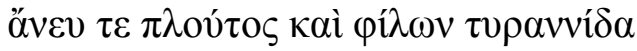

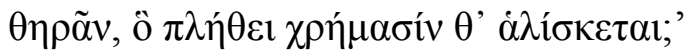

'Isn't it foolish, your attempt

to hunt tyranny, which needs men and money,

without wealth or friends?' (Soph., OT, 540-2) ${ }^{144}$

As Edmunds points out, this is reference to the mercenaries, money to pay the mercenaries and friends that are needed for the successful tyrant's coup. ${ }^{145}$ These are all the elements that Herodotus describes Peisistratus as having before his final, successful attempt at tyranny: ${ }^{146}$ he had philoi, his guest-friend Lygdamis of Naxos and several city states, that helped finance his campaign (as well as local followers); his conquest of a part of Thrace rich in silver was a

\footnotetext{
${ }^{144}$ Oedipus also elaborates on wealth as a temptation to tyrannical power to Tiresias:

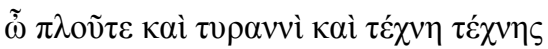

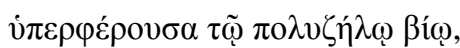

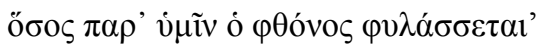

O power, wealth and empire, skill surpassing

skill in this cut-throat world,

how much envy you guard inside you' (Soph., OT, 380-2)

${ }^{145}$ Edmunds, L. (2002). "Oedipus as Tyrant in Sophocles' Oedipus Tyrannus," Syllecta Classica. 13(1): 63-103: p. 50.

${ }^{146}$ Hdt. 1.61.3-4
} 
source of ploutos. With this money, he hired mercenaries (plethos) with whom he became tyrant of Attica. ${ }^{147}$

\subsection{Aeschylus (Persae)}

The common antithesis between tyranny and democracy is first seen in Aeschylus' Persae. ${ }^{148}$ This is of the more straight-ford examples of the democracy/tyranny antithesis. However, it is not actually an example of anachronism as Persae is set during the recent Persian Wars and not in the heroic past. It is also the only strong example of the antithesis in Aeschylus. In Persae, the democratic Greeks are contrasted with the despotically ruled barbarians. ${ }^{149}$ Here, again, the Greeks are portrayed as free and democratic: when Atossa asks the Chorus about who rules Athens, Atossa is surprised to find that the Greeks were able to conquer her son's army without a monarch. ${ }^{150}$ The Greeks' rallying cry is given as:

$\tilde{\omega} \pi \alpha \tilde{i} \delta \varepsilon \varsigma^{\circ} \mathrm{E} \lambda \lambda \eta \dot{\nu \omega \nu}$ ǐ $\tau \varepsilon$,

$\dot{\varepsilon} \lambda \varepsilon v \theta \varepsilon \rho 0 \tilde{\tau} \varepsilon \pi \alpha \tau \rho i ́ \delta ’, \dot{\varepsilon} \lambda \varepsilon v \theta \varepsilon \rho 0 \tilde{\tau} \tau \varepsilon \delta \dot{\varepsilon}$

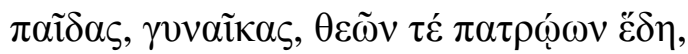

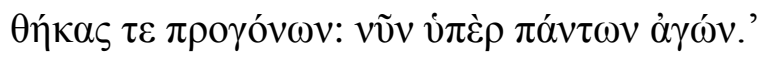

'Forward, you sons of Hellas!

Free your country! Free your children,

your wives, your ancestral tombs,

And the temples of your gods. Now is the battle for everything!' (Aesch., Pers., 401-

4)

The idea is that the Greeks won because they have something to lose if they are defeated: their freedom. It is this that makes them stronger than the Persians. ${ }^{151}$ This is illustrated more strongly in Atossa's dream where, when the personifications of Persia and Greece have been yoked to Xerxes' chariot, Persia is obedient and accepts the yoke, but Greece shakes it off

\footnotetext{
${ }^{147}$ However, it was also possible to perform a coup with only a small group of men -Polycrates allegedly only had 15 (Polynaeus, 1.23), Evagoras of Cyprus 50 (Isoc., Evag., 28).

148 Easterling, 1985, 2-3; West, 2013, 197-9

${ }^{149}$ West, 2013, 199

${ }^{150}$ Aesch., Pers., 241-4

${ }^{151}$ West, 2013, 199. C.f. also Herodotus' remark (Hdt. 5.78) that the Athenians only became a great power once the Peisistratids were gone but were weak under the tyrants.
} 
and breaks the harness, spilling Xerxes onto the ground. ${ }^{152}$ The inferiority of Persian despotism (and by implication the superiority of Greek democracy) is also shown through the impious yoking of the Hellespont into a bridge of ships and the Chorus' prediction that the defeat of the army will lead to the Persian people to reject autocracy. ${ }^{153}$

\subsection{Sophocles (Oedipus Tyrannus)}

The second time this is seen, and the only clear-cut Sophoclean example, is in Episodes One and Two of Oedipus Tyrannus during the agon scenes between Oedipus and Tiresias and Creon. ${ }^{154}$ Here we have the antithesis between democracy and tyranny take the form of a contrast between a democratic and a tyrannical character for the first time. The virtuous democratic characters are used to emphasise the idea of the tyrant as a moral monster, who displays the exact opposites of conventional Greek virtues. Several examples, including the two best, Euripides' Supplices and Phoenissae, have the antithesis between democracy and tyranny expressed as a debate between a tyrannical and a democratic character.

In this example, when Oedipus tyrannically accuses Tiresias and Creon of conspiracy, Creon and Tiresias anachronistically appeal to their equal rights, using words which are cognates of 'isos', 'equal'. ${ }^{155}$ Both of them are appealing to Athenian democratic rhetoric where equality was expressed mostly in terms beginning with '-is' ('equal'): 'isonomia' ('equal rights'), 'isegoria' ('equal right of speech') and 'isokratia' ('equal power'). These democratic rights could be taken away by a tyrant - as a tyrant would take away the people's freedom of speech and power to govern themselves. Tiresias claims it is his equal right to reply equally to

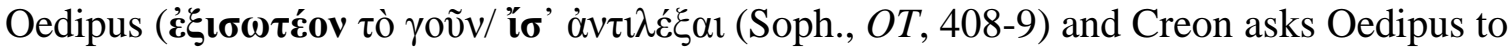

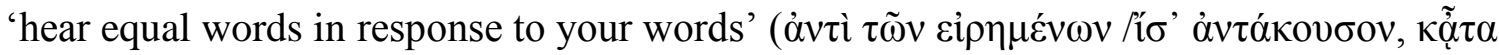

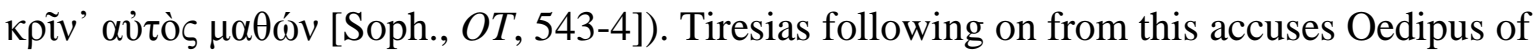
treating him like a slave by violating his freedom of speech:

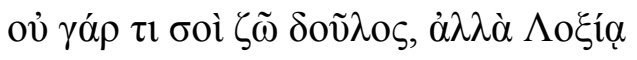

For I am not your slave, but Loxias' (Soph., OT, 410)

\footnotetext{
${ }^{152}$ Aesch., Pers., 176ff.

${ }^{153}$ West, 2013, 198-9: Something similar, but less developed happens in Aeschylus' Supplices where Pelasgus' democracy is contrasted with the autocratic regime of the Egyptians who are trying to make the Danaids marry their cousins.

${ }^{154}$ Soph., OT, 380-446; 532-633. While the Antigone has plenty of commentary on tyranny, it doesn't show as strong as example of the tyranny/democracy antithesis as Oedipus Tyrannus.

${ }^{155}$ Edmunds, 2002, 76
} 
Creon, on the other hand, claims that he is being treated unfairly because he and Jocasta have equal power with Oedipus:

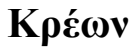

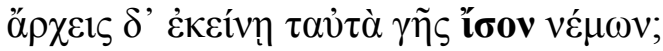

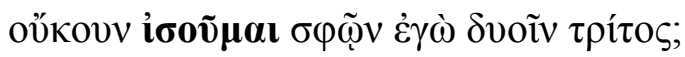

\section{Creon:}

Do you rule the land, sharing it equally with her?

Am I not then an equal third to you two? (Soph., OT, 579-581)

However, Creon's case is more complicated. Even Creon himself admits that he, Oedipus and Jocasta had equal de facto power. ${ }^{156}$ Creon describes his power in line 593 as 'dunasteia', which can mean 'lordship' or 'influence' but also a type of oligarchy which Aristotle claimed was to oligarchy what tyranny was to monarchy and was the word used to describe the rule of the thirty tyrants. ${ }^{157}$ Creon's admission of this power dynamic, as Edmunds points out, undermines his arguments, especially as Athenian democratic rhetoric was wont to conflate de facto tyranny and actual tyranny as can be seen in the comic depictions of Pericles and Thucydides' calling Pericles' rule the rule of a first citizen. ${ }^{158}$ Because he still holds power, Creon has no objection to tyranny as such as long as he is a participant in it and not its victim. This characterisation of Creon exculpates Oedipus somewhat. ${ }^{159}$

\footnotetext{
156 Edmunds, 2002, 76

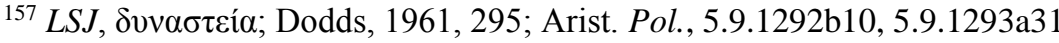

${ }^{158}$ Cerri, 1982, 142-3

${ }^{159}$ With the exception of Edmunds, 2002, 81, the consensus on Creon in the $O T$ is that he is exemplary, though conventional to the point of boring.
} 


\subsection{Euripides}

Euripides was fonder of this anachronistic contrast than either Aeschylus or Sophocles and so we can find more examples of it in his plays. In Supplices, as in the Heracleidae ${ }^{160}$ the democratic Athenians are defenders of suppliants from tyrants who want to harm them. In Supplices, the impiety of Creon in refusing to bury the bodies of the Theban warriors is contrasted with the piety of the democratic king Theseus as he champions the cause of the Theban exiles and shows democracy positively upholding Panhellenic values. ${ }^{161}$ This thematic thread, however, earlier comes to a head in the agon between Creon's symbolic stand-in, the pro-tyranny Theban messenger, whose characterisation as haughty and rude adds to the image of Theban tyranny, and Theseus. This agon has considerable similarities with Herodotus' Constitutional Debate, with the Herald's speech being similar to Megabyzos' speech and Theseus' being similar to Otanes'.

The similarity to the Constitutional Debate is particularly significant, as the Theban Herald's arguments are more similar to those of Megabyzos, the speaker for oligarchy in the Constitutional Debate, ${ }^{162}$ than Darius, the speaker for monarchy, thus making this an example of the conflation between oligarchy and tyranny. That there is a reference to oligarchy is

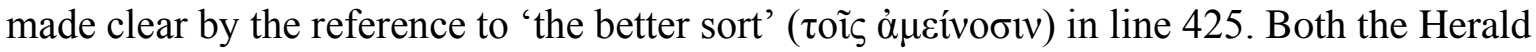
and Megabyzos use the more derogatory ochlos 'mob', among other words, when talking about the people. ${ }^{163}$ They both argue that the people are not intelligent enough to rule, ${ }^{164}$ and Megabyzos believes that this lack of good judgment cannot be cured by education, but is innate:

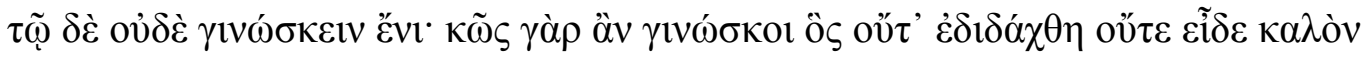

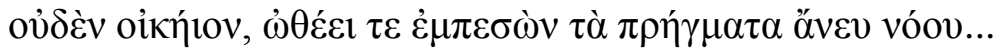

\footnotetext{
${ }^{160}$ Heracleidae has a very similar situation with its contrast between the absent tyrant Eurystheus threatening the suppliant Heraclids and the democratic king Demophoon protecting them.

${ }^{161}$ Lanza, 1977, 102

162 Hdt. 3.81

${ }^{163}$ Eur., Supp., 411

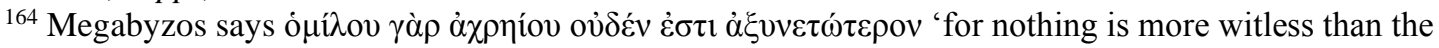
worthless crowd' (Hdt. 3.81.1), whereas the messenger states:

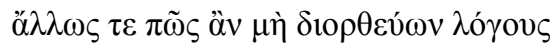

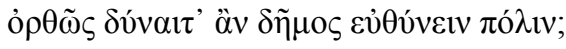

How, without judging words rightly,

Can the people steer straight the polis? (Eur., Supp., 417-8)
} 
But the [people] do not know: for how could that which had neither been taught anything noble nor knows it naturally, but forces itself upon and falls upon affairs thoughtlessly...(Hdt. 3.81.2)

The last part of this quote shows Megabyzos believes that the demos rushes into bad decisions and the Theban Herald agrees with this when he devotes his speech to the dangers of demagogue politicians who 'turn [the people] one way then another for private gain'

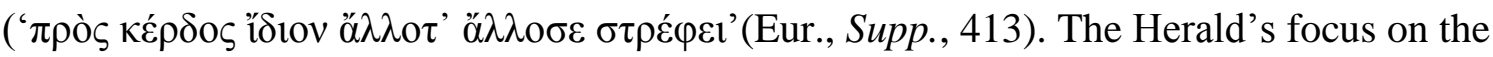
dangers of demagoguery is the main difference between his speech and Megabyzos' - the

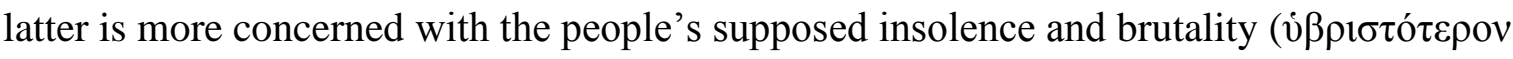

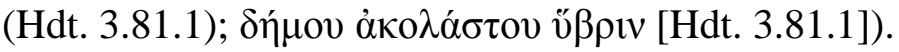

To the messenger's speech, Theseus gives a speech with some degree of similarity to that of Otanes' in the Constitutional Debate. ${ }^{165}$ This speech, like Otanes' in the Constitutional Debate but in less detail, ${ }^{166}$ mostly shows democracy as good through the evils of tyranny and is thus an example of the anachronistic technique of using tyranny as a foil for democracy. As in the Constitutional Debate, Theseus' speech gets more space than his un-democratic rival.

Theseus and Otanes both point out the tyrant's tendency to kill the best men in the city, and how this comes from fear or envy. ${ }^{167}$ They also characterise their tyrant as a rapist. ${ }^{168}$ Both speakers also point out the tyrant is unaccountable and democracy accountable - the tyrant

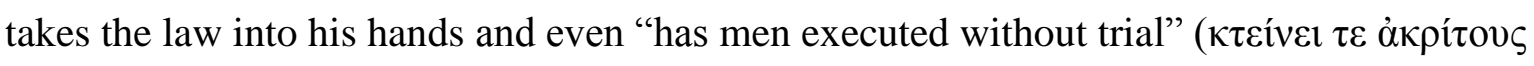
(Hdt. 3.8.5), whereas under democracy the magistrates are held responsible for their actions. ${ }^{169}$ This is one of the few benefits of democracy actually mentioned; the other is the assembly. ${ }^{170}$

Not related to the Constitutional Debate but worth noticing is line 438 that contains the formula used by the herald to open the proceedings at the Athenian assembly, and the purge of the aristoi is expressed in very similar terms to the famous anecdote of Thrasybulus and the cornfield in Herodotus: ${ }^{171}$

\footnotetext{
${ }^{165}$ Eur., Supp., 426-462; Hdt. 3.80, Lanza, 1977, 97

166 Theseus for example doesn't explicitly mention hybris.

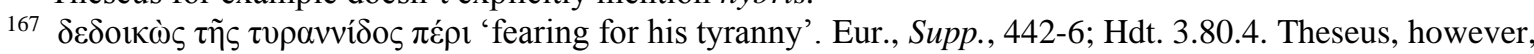
does not concentrate on the tyrant's other emotional deficits, such as anger.

${ }^{168}$ Eur., Supp., 452-4; Hdt. 3.80.5

${ }^{169}$ Eur., Supp., 430-7; Hdt. 3.80.5-6

${ }^{170}$ Eur., Supp., 438-441; Hdt. 3.80 .6

${ }^{171}$ C.f. Hdt. 5.92f-g
} 


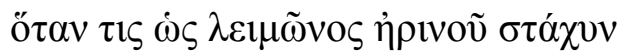

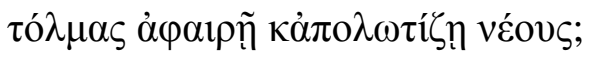

Whenever someone, as if cutting away flowers from a cornfield in spring

Takes away daring and cuts away the young? (Eur., Supp., 448-9)

Another example of the contrast is seen in Euripides' Electra where Aegisthus, the unmanly tyrant, is contrasted with Electra's husband, the poor but virtuous farmer, who is portrayed as a democratic everyman. ${ }^{172}$ The peasant farmer in Electra is shown to be the model of arete, showing the virtues expected of a Greek man-manliness and respect for the oikos, ${ }^{173}$ respect for xenia, ${ }^{174}$ sophrosyne, ${ }^{175}$ piety, humility, ${ }^{176}$ and nobility of character. ${ }^{177}$ In particular, the farmer's poverty is contrasted with his nobility of character:

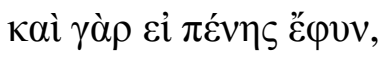

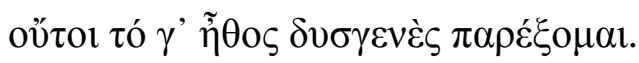

For even if I am poor,

I will not indeed show low-born manners. (Eur., El., 362-3) $)^{178}$

172 See Lanza, 1977, 124-8. Lanza, 1977, 128, disagrees with me here. For the general idea see Hanson, V., D. (1999). The Other Greeks: The family farm and the agrarian roots of western civilisation. Berkley and Los Angeles: University of California Press.

${ }^{173}$ Lanza, 1977, 125-6, 128. C.f. Eur., El., 253-262. In particular, the farmer has an appropriately dominant and masculine relationship with his wife Electra as opposed to the situation with Clytaemnestra and Aegisthus. This is seen most prominently at his very proper reaction to seeing Orestes and Pylades, who are at this point are strangers to him, with Electra, when the farmer shows himself to be concerned for Electra's honour:

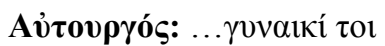

$\alpha i \sigma \chi \rho o ̀ v \mu \varepsilon \tau^{\prime}$ '’ $v \delta \rho \tilde{\omega} v \dot{\varepsilon} \sigma \tau \alpha \dot{v} \alpha \alpha \imath \varepsilon \alpha v i \tilde{\omega} v$.

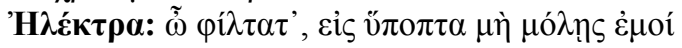

Farmer: ... It is indeed

Shameful for a woman to be standing with young men.

Electra: Dearest, don't come and be suspicious of me... (Eur., El., 343-345)

${ }^{174}$ Eur., El., 357-363, 394-5

${ }^{175} \mathrm{He}$ is described as $\sigma \omega ́ \varphi \rho \omega v$ (Eur., El., 261)

${ }^{176}$ Eur., El., 253-262

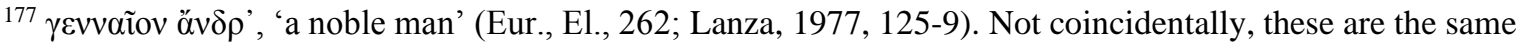
characteristics that were looked for in a 'good king', as we will see in chapter three.

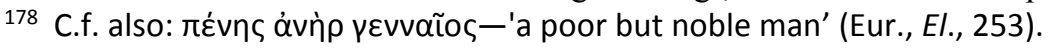


This comes to a climax when Orestes gives a speech extolling the farmer as an example of nobility being a characteristic not obtained by high birth but from nature (phusis) and merit: ${ }^{179}$

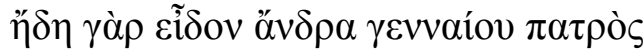

$\tau$

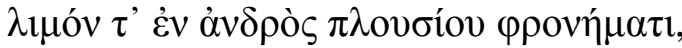

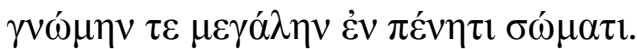

$\pi \tilde{\omega} \zeta$ ỡv $\tau 1 \zeta \alpha$ $\tau \grave{\alpha} \delta 1 \alpha \lambda \alpha \beta \omega ̀ v$ ỏ $\rho \theta \tilde{\omega} \zeta \kappa \rho ı \varepsilon \varepsilon \tilde{i}$;

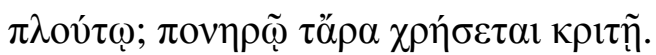

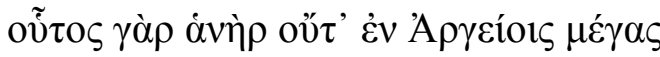

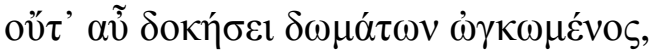

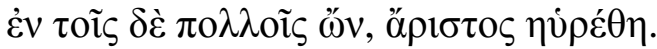

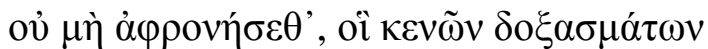

$\pi \lambda \eta ́ \rho \varepsilon เ \varsigma \pi \lambda \alpha v \tilde{\alpha} \sigma \theta \varepsilon, \tau \tilde{\eta} \delta^{\prime}$ ó $\mu \imath \lambda i{ }_{1}^{\alpha} \beta \rho o \tau o v ̀ \varsigma$

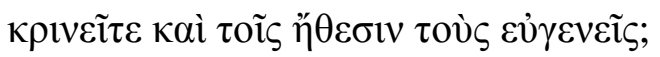

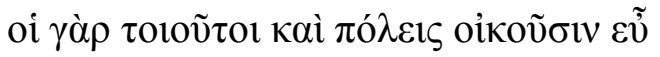

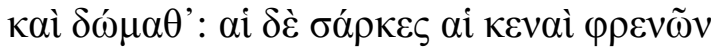

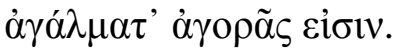

For by now I have seen men from noble fathers

To be nothing, and good children born from bad parents,

And famine in the heart of a rich man,

But a great mind in a poor body.

So how does one rightly separate and divide such things?

By wealth? It would be declared by a worthless judge.

For this man is neither great among the Argives

Nor again puffed up with the repute of his house,

But though he is among the many, he is found to be the best.

${ }^{179}$ Eur., El., 367-391. Lanza, 1977, 127-9. There is a similarity here with Protagoras' argument in the Protagoras or the example of phusis as a justification for democracy in Phoenissae that I will discuss below. 
So, lest you be foolish, you who wander around

full of empty opinions, should you not determine mortals

noble by association and their natures?

For such men govern both cities and homes

well: while flesh that is empty of intelligence

Is a just like a statue in the market-place. (Eur., El., 370-4, 380-9) $)^{180}$

These lines and especially 'But though he is among the many, he is found to be the best.' ('ं v

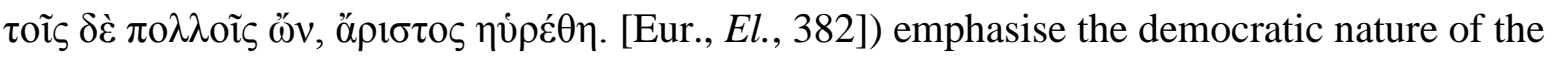
speech. Here it is stated that one's belonging to the demos does not stand in the way of arete, which is based, according to fifth century values, on the possession of virtues as opposed to more aristocratic and archaic elite descent and Homeric fighting prowess. The conclusion, lines 387-8 ('For such men govern both cities and homes/ well' ( yò

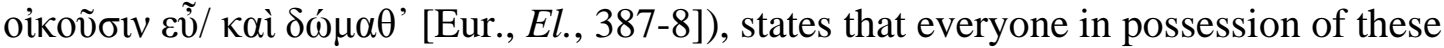
virtues, that is in possession of arete $\bar{e}$, the qualification for a Greek ruler, ${ }^{181}$ ought to have the right to rule their cities, and is strongly democratic.

Furthermore, this pro-democracy argument is strengthened by the usual tyranny versus democracy antithesis as Aegisthus is displayed as a tyrant with the opposite qualities to that of a good Greek man - he displays effeminacy, through his cowardice and lack of control of his wife, hybris, weakness of character, impiety and lack of sophrosyne. ${ }^{182}$ This portrayal, when contrasted with the farmer's, shows tyranny in a bad light compared with a democracy made of upright everymen. ${ }^{183}$ However, as in Supplices, there is more going on - the boundaries between tyranny and oligarchy are being blurred, here incriminating the latter with the former's crimes. Aegisthus is the essence of the corrupt, arete-less noble whom Orestes rails at, which when combined with his tyrannical characteristics, also serve to display oligarchy, through the lack of virtue of the aristoi ${ }^{184}$ in a negative light.

\footnotetext{
${ }^{180}$ The pro-democracy tone of this speech is blunted by the presence of the ideology of 'to meson'. The next lines (Eur., El., 375-7) condemn poverty as a basis for aretē in a very similar way to Aristotle.

${ }^{181}$ Morris, 1996, 40

${ }^{182}$ Lanza, 1977, 124-9

${ }^{183}$ Somebody like Andrewes might even go as far to say that he symbolizes the hoplite farmer that provides the base of the Athenian army and democracy.

${ }^{184}$ The sort of Morris' older tradition, the oligarchs.
} 
In Phoenissae, the antithesis between tyranny and democracy is explicitly expressed in an agon between two characters, but the ideology is updated. ${ }^{185}$ In this agon scene, ${ }^{186}$ Eteocles, tyrant of Thebes, argues that tyranny is a great thing while his mother Jocasta argues that equality is. However, this agon contains late fifth century ideas about phusis and justice that do not occur in earlier examples. Eteocles' argumentation here is even more anachronistic than that of the Theban messenger, as he does not use conventional argumentation for tyranny, but argues that the conventional arguments against it are irrelevant. Here Eteocles argues according to expediency instead of justice - this was known as the "Unjust Argument", arguing that even if one's actions are unjust, they are a good idea under the circumstances. ${ }^{187}$ The Unjust Argument was opposed to the conventional "Just Argument" which involved arguing that one's actions were just. ${ }^{188} \mathrm{He}$ argues he is perfectly justified in holding onto his tyranny, because the arguments against tyranny are flawed and it would be bad for him if he gave it up. ${ }^{189}$

The argumentation used here has much in common with the "unjust" arguments for tyranny expressed by Polus and Callicles in the Gorgias and Thrasymachus, Glaucon and Adeimantus in the Republic. ${ }^{190}$ Eteocles uses ideas similar to those seen in these dialogues to prove that it is right or at least an intelligent course of action to seek tyranny. His attitude is expressed over across his speech, quoted here in part for reference:

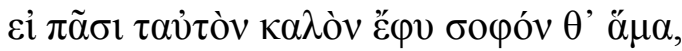

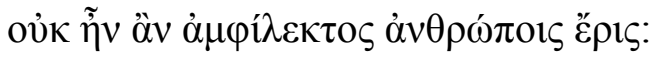

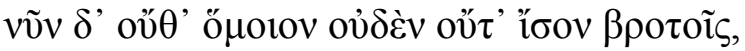

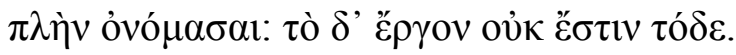

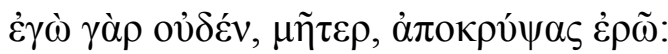

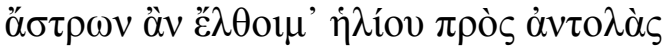

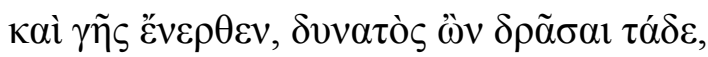

\footnotetext{
${ }^{185}$ Lanza, 1977, 97-8

186 The agon also includes a small speech by Eteocles' rival and brother Polyneices, but this has little bearing on the argument here, and the real contrast is between Eteocles and Jocasta's speeches.

${ }^{187}$ C.f. Aristoph., Clouds, 889-1105, where the "Just" and "Unjust" Arguments are personified.

${ }^{188}$ C.f. the dikaios logos and adikos logos in Aristophanes' Clouds.

${ }^{189}$ Pearson, L. (1962). Popular ethics in ancient Greece. Stanford: Stanford University Press: pp. 166-7

190 There are also similarities to the conventional view of tyranny as something that any man in his right mind would wish to attain (especially the point of view of the imaginary accuser of Solon in Fragment 33 West).
} 


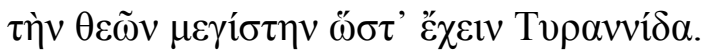

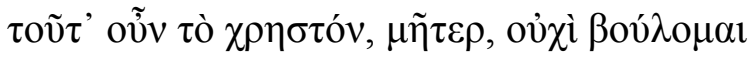

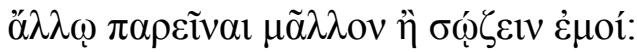

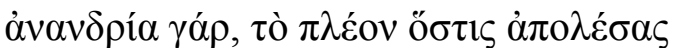

$\tau o ̛ ̋ \lambda \alpha \sigma \sigma o v$ ع̌ $\lambda \alpha \beta \varepsilon \ldots$

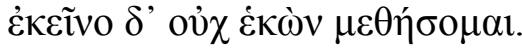

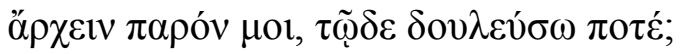

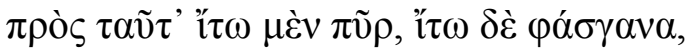

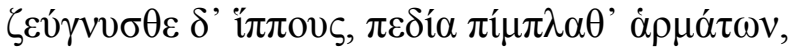

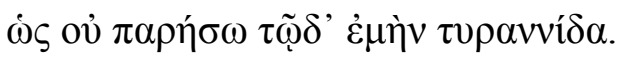

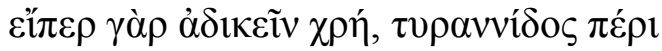

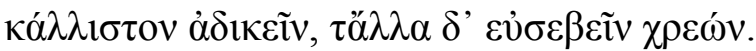

If the good and the wise were the same for all,

There would be no disputing strife among men,

But, now, there is neither fairness nor equality among men,

Beyond giving them names: but they do not exist in practice.

For I will speak, mother, keeping nothing hidden;

I would go to the rising of the stars and the sun

And beneath the earth, if I was able to do these things,

To have Tyranny, greatest of the gods.

Therefore, mother, I am not willing to yield

This good thing to another, instead of saving it for myself...

Having it [tyranny], I will not let it go.

To be made his slave, if I can rule? 
Therefore, let fire and sword come,

And yoke the horses, fill the plain with armed men,

As I will not give up my tyranny for him.

For if one must do wrong, it is best to do wrong

On account of tyranny, but one should be pious in all other matters. (Eur. Phoen., $500-510 ; 519-525)$

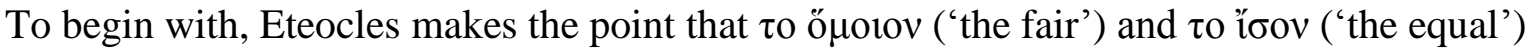

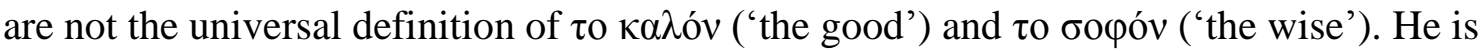
essentially arguing, like Plato's Callicles, Thrasymachus and Glaucon that justice (dikaisoune) exists according to nomos or human custom or law (which explains why it differs in different places). ${ }^{191}$ This is a use of the fifth century idea of nomos, human custom, and phusis, nature, which is used to devalue the conventional view of justice in multiple places in Plato's Gorgias and Republic. Callicles in the Gorgias argues that nomos justice is actually a set of rules made up by the weaker to prevent the strong from gaining power. ${ }^{192}$ Likewise, Thrasymachus argues that justice is whatever is in the interest of the strongest (ruling) party. ${ }^{193}$ Glaucon argues that justice is a way of making sure we don't suffer injustice by promising as a society to not commit it. ${ }^{194}$ The conclusion is that if justice as we know it is a social construct and does not bring any benefit in and of itself, it is not necessary to obey it.

Before going onto the logical conclusion that injustice (adikia) is in fact $\tau$ o $\kappa \alpha \lambda o ́ v$, Eteocles also makes the related point that it doesn't matter what justice is if no one obeys it.

Something similar is also seen when Glaucon and Adeimantus argue that people are only just so that they can get a reputation for justice and that if they can contrive to get a reputation for justice without being just they will do so. ${ }^{195}$ Glaucon points out with the example of Gyges' ring that if you gave an unjust and a just man the ability to do what they like without fear of consequences, they would both behave unjustly. ${ }^{196}$

\footnotetext{
${ }^{191}$ Plato, Resp., 343b-d (Thrasymachus); 358a-361d (Glaucon); Plato, Gorgias, 491e-492d; 482c-486d (Callicles)

${ }_{192}$ Plato, Gorgias, 483b-d

${ }^{193}$ Plato, Resp., 338c-339b

${ }^{194}$ Plato, Resp., 358e-359b

${ }^{195}$ Plato, Resp., 360b-362a; 363a-b

${ }^{196}$ Plato, Resp., 359c-360c
} 
Eteocles next goes on to characterise tyranny as 'a good' ( and 'the greatest of the gods' ( might allude to the idea seen in Plato that conventional (nomos) justice is according to phusis actually just - Callicles in particular argues that phusis-based justice is the rule of the stronger and tyranny is the best example of this. ${ }^{197}$ Polus and Glaucon also both argue that doing wrong and the power that comes from it is naturally a good. ${ }^{198}$ Thrasymachus does not say that the good is injustice, which he defines as acting in your own interests, ${ }^{199}$ but implies it when he defines justice as the interest of the stronger party-if neither justice nor injustice is right, then it is better to choose injustice because it pays better. ${ }^{200}$ This is what Eteocles is thinking here: he will gain much more from keeping the throne than justly giving it up to his brotHdt. This is also the theme of the infamous last two lines of the speech: ${ }^{201}$ by doing wrong, Eteocles can obtain tyranny, far more than if he is just (and as he says later Tyranny is such a good thing that it is worthwhile to be unjust for it). Tyranny, in fact, is the example given by Thrasymachus of why doing wrong is better than doing right — tyranny is such a good prize that everyone forgets that the tyrant has done wrong and praises him for his good fortune. ${ }^{202}$ The example of Archelaus given by Polus in the Gorgias also exemplifies this Archelaus has done wrong by killing his family members to become king. However, his wrongdoing has put him at the height of good fortune and power and so no longer appears to matter when compared to its reward. ${ }^{203}$ This line of thought is continued with 'To be made

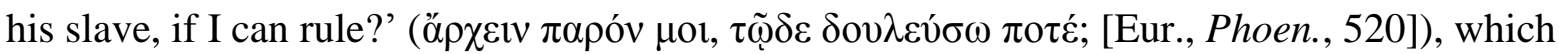
expresses the sentiment of Polus in the Gorgias, that it is better to commit injustice than to suffer it, demonstrated in the Gorgias by the contrast of the fates of the man who attempts a tyranny and fails (death and torture) and the one who succeeds (power and happiness). ${ }^{204}$

\footnotetext{
${ }^{197}$ Plato, Gorgias, 338e-339b; Dodds, 1961, 13-5

${ }^{198}$ Plato, Resp., 358e; Plato, Gorgias, 466-7

199 Plato, Resp., 343c

${ }^{200}$ Plato, Resp., 343b-e

${ }^{201}$ Eur., Phoen., 524-5

202 Plato, Resp., 344a-c

203 Plato, Gorgias, 471a-d

C.f. also Williams, M.F. (2005). “ 'Because you spoke abuse against the king' ": Parrhesia and Tyrannicide in Euripides' Medea" in Constantinidis, S.E. (ed.), Text and Presentation 2004. Jefferson and London: Mcfarland \& Company: 20-34: pp. 28-9 on Medea: Rejection of conventional morality in relation to tyranny is also seen in Euripides' Medea where Medea ignores law, custom and conventional morality to fulfil her goal-revenge on her husband - by killing her children, Creon and Creusa and uses sophistic rhetoric to justify her actions. ${ }^{204}$ Plato, Gorgias, 469b-c; 473c-d; 482d-e

Eteocles makes the same mistake of Polus in the Gorgias and admits that he is doing is adikein instead of going with Callicles and stating that what he is doing is actually right under an alternative value system based on phusis. (Plato, Gorgias, 482d-e; Dodds, 1961, 11-2)
} 
Eteocles' mother, Jocasta, replies to this speech with one on the merits of democracy. Like Eteocles, she uses personifications, 'Equality', Isotes, (Eur., Phoen., 536, 542), and 'Ambition', Philotimia, (Eur., Phoen., 532), to make her point. ${ }^{205}$ Jocasta uses a mixture of conventional wisdom and recent political ideas. She appeals to phusis, but she argues that equality is phusis. Jocasta emphasises the idea of Equality as phusis by making the personified Equality responsible for not just the equality seen in human politics, but in other spheres of human influence like weights and in nature (phusis) itself where the moon and sun are able to take turns. ${ }^{206}$ She also emphasises the more political role of Equality in peace and relationships between cities and individuals. ${ }^{207}$ This is bought back into context later in the speech when Jocasta places before her son two alternatives - remaining tyrant for the time being and having his city destroyed or giving into equality with his brother and saving his city. ${ }^{208}$ The message is clear, a city cannot exist without equality, its natural state; without equality the polis will be destroyed. The threatened physical destruction of Thebes symbolises its metaphorical destruction under the rule of its tyrant. ${ }^{209}$ Jocasta also highlights expediency, pointing out that there is no real benefit in tyranny, as it is only a name so there is no point in pursuing it, mirroring the beginning of her son's speech:

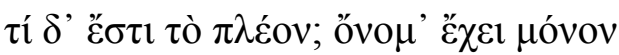

What is the greater thing? It is only a name (Eur., Phoen., 553)

Jocasta even references the gods in relation to expediency; if mortals are but caretakers of the gods' property, what is the point in striving to protect or win such property if you cannot keep it $?^{210}$

Jocasta also uses the more traditional argument again tyranny and ambition: they are unjust, ${ }^{211}$ directly contradicting Eteocles' attempts to transvalue justice earlier in the agon.

\footnotetext{
${ }^{205}$ Lanza, 1977, 134-5

${ }^{206}$ Eur., Phoen., 541-545

${ }^{207}$ Eur., Phoen., 536-8

${ }^{208}$ Eur., Phoen., 559-567

${ }^{209}$ Lanza, 1977, 139: Haemon also points out in line 737 of Antigone that a city ruled by one man is no city.

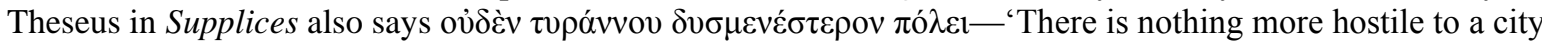
than a tyrant.' (Eur., Supp., 429).

${ }^{210}$ Eur., Supp., 555-8. The notion of the mutability of fate and wealth, of course, is quite conventional.

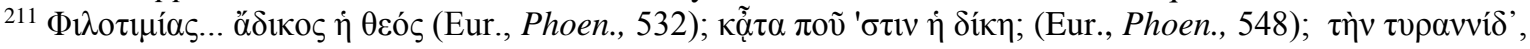

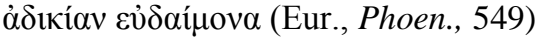




\section{Conclusion:}

Political anachronism is common, if not quite ubiquitous, in Greek tragedy, and it is used to discuss contemporary political issues. Depicting tragedy as set in the polis, instead of solely in the Homeric world, along with including other elements of contemporary political life such as money, allows contemporary political ideas like democracy and tyranny to be depicted. Of the ideas about tyranny that we see in tragedy, the most prominent are the fifth century ideological concepts of the tyrant as evil and the antithesis between tyranny and democracy, which appear again and again, alongside other concepts like the contrast between tyranny and oligarchy and political uses of the nomos versus phusis dichotomy. The antithesis between tyranny and democracy may be by a simple juxtaposition of themes, as in Aeschylus' Persae, or a juxtaposition of democratic and tyrannical characters as in most Sophoclean and Euripidean examples. The tyranny/democracy antithesis, and in fact explicit discussion about tyranny, is seen more often in Euripides than Aeschylus and Sophocles, as we can see from the fact that there is only one clear example each of the tyranny/democracy antithesis in Aeschylus and Sophocles. 


\section{Chapter Three: Tyrant Tropes in Tragedy:}

As we said in chapter two, the vilification of tyranny is one of the ways in which tragedy incorporates political anachronism and discusses contemporary political ideas. This is most effectively done through the tragic tyrant. The tragic tyrant is part of a wider framework of anachronistic portrayals of tragic kings, which developed to explore contemporary political ideas. $^{212}$ This is recognised by several modern scholars, producing the classification of tragic tyrant, Homeric (non-anachronistic) king, Eastern King and democratic king. ${ }^{213}$ I agree with these classifications, but I would like to add the types of the "semi-tyrant" and "good king".

The stereotypes that we see in the tragic tyrant are often very similar to those seen in fourth century writings, when the stereotyped tyrant was actually codified. While there are differences between individual tyrants, those, when accounted for, do not prevent us from making conclusions about tyrants as a group in order to arrive at patterns in the portrayal of tragic tyranny. Some rulers are weakly characterised as tyrants ("semi-tyrants"), tyranny only being used to add a negative moral judgement to their characters, but others were characterised fully into what we can call the tragic tyrant. The stereotyped tyrant, tragic or otherwise, is a composite of rule-preserving and purely moralising traits. The rule-preserving traits include illegitimate routes to power based on stasis, excessive suspicion and fear, use of murder and oppressive methods to preserve power and taking away the rights of the people. The moralising traits include lack of self-control (akrolasia) and impiety.

On the other side, we see the tyrant's ideological opposite, the good king, both in his pure form and as the democratic king. The good king is a figure who is again codified by the fourth century philosophers, and he is, as described in chapter one, characterised by his outstanding arete. The oriental king is seen occasionally and portrayed with varying degrees of sympathy. The non-anachronistic figure of the Homeric mythical king also occurs.

\footnotetext{
${ }^{212}$ Easterling 1985; West 2013; Cerri 1982, Perris 2017; Perris 2018

${ }^{213}$ The existence of other forms of government that do not involve one-man rule will not be discussed here in any depth. See West 2013; Perris 2017.
} 


\subsection{Types of tragic rulers:}

Several different ways of categorising tragic rulers and regime types have appeared in modern scholarship. Seaford believes that the tragic king had to be reconstituted as a tyrant in order to cohere to Athenian attitudes that sole rule was bad. ${ }^{214}$ Easterling comes up with a more complex theory—she acknowledges the tyrant, also eastern hereditary kings and the democratic 'first-citizen' kings, ${ }^{216}$ which is very similar to the opinions of West and Perris. ${ }^{217}$ Easterling and West also point out that democracy is used to characterise a king as good. ${ }^{218}$ Perris, along with Cerri, says that some kings in tragedy are not anachronistically characterised but rather just mythical kings. ${ }^{219}$ However, sole rule is not the only regime type which occurs in Greek tragedy: West and Perris suggest the existence of a theocratic system in Eumenides. ${ }^{220}$ Perris goes further to describe the regime type in tragedy set in the Greek camp of the Trojan War as a military alliance and a form of aristocracy operating at Delphi in Ion. ${ }^{221}$ These could also be considered anachronistic regimes.

Seaford, in my opinion, inadequately addresses alternative methods of anachronistically characterising tragic kings, only mentioning Theseus in passing and only to describe him as a 'good king'. ${ }^{222}$ While I agree with West's, Easterling's and Perris' theories on types of tragic ruler, I would argue that that the categories into which tragic rulers can be placed are more complicated. There seems to be many examples of tragic rulers who have a few tyrannical features but cannot really be defined as tyrants. In fact, here I will argue that Creon in Antigone, Aegisthus in Agamemnon and Euripides' and Sophocles' Electra, Lycus in Heracles furens, Zeus in Prometheus vinctus, Eteocles in Phoenissae and Oedipus in Oedipus Tyrannus are the only fully developed examples of the tragic tyrant. I will also argue that there is evidence for "good kings" who goodness is not based on their democratic regime.

\footnotetext{
${ }^{214}$ Seaford, 2003a, 101-2

${ }^{216}$ For simplicity we will call these 'democratic kings'.

${ }^{217}$ Easterling, 1985, 3; Perris, 2018; West, 2013, 195; 202

${ }^{218}$ Easterling, 1985, 3; West, 2013, 202

${ }^{219}$ Cerri, 1982, 147; Perris, 2017, 329-30; 334; Perris, 2018

${ }^{220}$ West, 2013, 201; Perris, 2018

${ }^{221}$ Perris, 2018

${ }^{222}$ Seaford, 2003a, 104. Seaford, as Simon Perris has pointed out to me, is rather narrow in his categorisation of tragic rulers, however his mention of Theseus as a good king does show he recognises other paradigms of tragic kings apart from tragic tyrants.
} 


\subsection{The tyrant tropes as seen in prose:}

Before we study the tragic tyrants and their tyrannical characteristics, we must first establish the existence of these characteristics in the prose sources which list the features of a tyrant. The tyrant's characteristics are categorised in Aristotle's Politics, ${ }^{224}$ Plato's Republic, ${ }^{225}$ and Xenophon's Hiero, ${ }^{226}$ as well as in Herodotus' famous Constitutional Debate. ${ }^{227}$ There is a visible development of the tropes between Herodotus and the fourth century sources, though there can scarcely be said to be one between the earlier fourth century Plato and Xenophon and the later fourth century Aristotle.

Aristotle in the Politics and Plato in the Republic give a range of causes of tyranny, which can essentially be simplified into ambition and stasis. Ambition (philotimia), combined with a lack of scruples and moral compass, is given as the main reason for a man to aim at tyranny; the power and wealth that tyranny gave was highly attractive, ${ }^{228}$ especially if someone thought his opportunities were limited under his city's current constitution. ${ }^{229}$ Stasis was considered both a cause of tyranny and a means of achieving it. Stasis, as explained in chapter one, could have a variety of causes. However, the ancients believed the type of stasis responsible for tyranny was class stasis, stasis between the people and the rich. This could arise through the cruelty of the aristocrats, ${ }^{230}$ or, the most likely cause, through the machinations of a demagogue aiming at tyranny. ${ }^{231}$

Plato gives the demagogue's path to power in more detail. Firstly, the demagogue claims he hates the rich and accuses them of aiming at oligarchy to turn the people against the aristocrats. ${ }^{232}$ This in turn causes the aristocrats to form an oligarchic faction, which leads to stasis. ${ }^{233}$ Amid this, the demagogue becomes the people's champion ('prostas tou demou'). ${ }^{234}$ After trying to exile the demagogue, the aristocrats may try to assassinate him, or if they do not, he will injure himself and pretend that he escaped an assassination attempt. ${ }^{235}$

\footnotetext{
${ }^{224}$ Arist. Pol. 5.9.1313a 2-9

${ }^{225}$ Plato, Resp., 8.562-569

${ }^{226}$ Xen., Hiero, passim

${ }^{227}$ Hdt. 3.80-82. They are also categorised in Theseus' agon speech of Euripides' Supplices which has already been discussed above.

${ }^{228}$ Arist., Pol., 5.9.1302b

${ }^{229}$ Arist., Pol., 5.9.1307a

${ }^{230}$ Arist., Pol., 5.9.1306b

${ }^{231}$ Arist., Pol., 5.9.1305a-b

${ }^{232}$ Plato, Resp., 565b; Arist., Pol., 5.9.1305a1

${ }^{233}$ Plato, Resp., 565b

${ }^{234}$ Plato, Resp., 566c

235 Plato, Resp., $566 \mathrm{~b}$
} 
Peisistratus, for example, claimed his first tyranny by cutting himself and his mares and driving his chariot into the agora, pretending he had been attacked outside the city. ${ }^{236}$ This causes the people, afraid for the demagogue's life, to grant him a bodyguard — which he uses to complete the tyrant's coup d'état. ${ }^{237}$ This, the "bodyguard trick", was allegedly the path to power for three different tyrants - Theagenes, Peisistratus, and Dionysus. ${ }^{238}$ It was also possible to execute a coup without feigning an assassination attempt and being given a bodyguard, for example Cypselus in Herodotus. ${ }^{239}$

A prospective tyrant could also use methods of trickery to attempt a tyranny. ${ }^{240}$ Peisistratus, when aiming at tyranny for a second time, sent men around Attica saying how Athena herself was welcoming him back into Athens. Then he found a tall and beautiful woman called Phye, who he dressed up as Athena. He rode back into Athens with this 'Athena' and was welcomed back with open arms. ${ }^{241}$ To attain his third tyranny, he attacked while his enemies were eating lunch. ${ }^{242}$ Polycrates of Samos took the island with fifteen men, using a festival as a pretext to bear arms. ${ }^{243}$

Once the tyrant achieves his position, then there are two different sets of tropes - those that relate to the conservation of the tyrant's rule (power-conserving tropes) and those that are mostly part of the tyrant's characterisation as a moral monster (moralising tropes). The tropes relating to the conservation of power, which also have a strong moral component, can often be identified by being actual strategies used by rulers-for example, execution and exile of enemies, confiscation of property, denying rights like parrhesia and freedom of movement, torture and use of secret police are all elements that occur and have occurred in real authoritarian regimes. ${ }^{244}$ However, as all of the writers tend to moralise, the power conserving tropes are only sometimes considered to be purely for the purpose of powerconserving, by the later forth century authors, instead of as a result of the tyrant's paranoia over assassination. It is also possible that this alternative view was the usual way of seeing the tyrant's actions, which was rationalised by later authors.

\footnotetext{
${ }^{236}$ Arist., Pol. Ath., 14; Hdt. 1.59.3-5

${ }^{237}$ Plato, Resp., 566b

${ }^{238}$ Arist., Pol., 5.9.1305a; Andrewes, 1963, 100

${ }^{239}$ Hdt. 5.92e1

240 The "bodyguard trick" also counts as this.

${ }^{241}$ Hdt., 1.60; Arist., Ath. Pol., 14.4

${ }^{242}$ Hdt. 1.62-3

${ }^{243}$ Hdt. 3.120.3, Polynaeus, 1.23

${ }^{244}$ A simple example of the tyrant's purge from antiquity would be the proscriptions of Sulla, Marius and Augustus.
} 
The tyrant's strategies for conserving his rule are summarised by Aristotle as: for the tyrant to keep his subjects humble and servile, to prevent them from trusting each other so that they cannot plot against him and to not give them political power with which they might overthrow him. ${ }^{245}$ The tyrant takes a number of direct precautions to prevent his assassination. First the tyrant must get rid of the rich, the best men and men of character who are likely to rebel against his rule (either by exiling or killing them). ${ }^{246}$ As the tyrant grows more unpopular, he will also have to get rid of many of his own supporters and friends. ${ }^{247}$ These purges are a key element of the tyrant's rule from Herodotus, where it is mentioned obliquely in the Constitutional Debate:

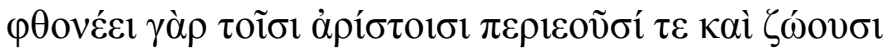

'For he envies the best men who live and thrive' (Hdt. 3.80.4)

The tyrant stereotypically replaces these upright men with base men, ${ }^{248}$ who do not mind tyranny and can be used for the tyrant's dirty work. ${ }^{249}$ The tyrant must also hire a bodyguard of foreign mercenaries (or freed slaves). ${ }^{250}$ Plato says he will pay these people with loot from his victims - and once these are dried up, taxes from the people. ${ }^{251}$

Initially, to keep the people on his side, the tyrant may continue to engage in populism by redistributing the land he has taken off his enemies to his supporters and the people and cancelling debts, but any goodwill from this is soon destroyed by the tyrant's oppressiveness. ${ }^{252}$ At the beginning of his rule in particular but also in general, the tyrant must stir up war so that the people need a leader and he can make them poor by war taxation and unite the state against a foreign enemy and not himself. ${ }^{253}$ The tyrant can also make the people poor and too busy to plot with constant building projects (the examples Aristotle gives are the Cypselids' votive offerings, Peisistratus' temple of Olympian Zeus and the Egyptian pyramids). ${ }^{254}$ Encouraging the people to attend the tyrant's palace as if he were an Eastern

\footnotetext{
${ }^{245}$ Arist., Pol., 1313a 8

246 Plato, Resp., 566 c., Xen., Hiero, 5.1-2

${ }^{247}$ Plato, Resp., 567c; Xen., Hiero, 3.6-8

${ }^{248}$ Again, seen as early as Herodotus: Hdt. 3.80.4. Xen., Hiero, 5.1-2

${ }^{249}$ Plato, Resp., 567d; Arist., Pol., 5.9.1314a1

${ }^{250}$ Plato, Resp., 567d-e; Xen., Hiero, 1.8; 6.5

${ }^{251}$ C.f. Kallet, L. (2003). "Dēmos Tyrannos: Wealth, Power and Economic Patronage”, in Morgan, K. A. (ed.),

Popular tyranny: sovereignty and its discontents in ancient Greece. Austin: University of Texas Press: 193

252 Plato, Resp., $566 \mathrm{c}$

253 Plato, Resp., 566e-567a

${ }^{254}$ Arist. Pol., 1313 b4
} 
monarch is also useful. ${ }^{255}$ The tyrant can beat, torture and execute his citizens at whim to keep them in line. ${ }^{256}$ These measures are only possible because the tyrant rules without regard to the law or constitution and does what he wants because he has no checks on his poweranother element which is important enough to be included in Otanes' speech in Herodotus' Histories. $^{257}$

The tyrant can also secure his rule by denying the people their rights. ${ }^{258}$ Freedom of speech (parrhesia) is restricted. ${ }^{259}$ Aristotle explains that some tyrants accomplish this by a network of spies or secret police, ${ }^{260}$ and even Herodotus includes the use of informers in the tyrant's methods. ${ }^{261}$ Aristotle also describes the tyrant restricting freedom of movement and association by banning public gatherings (including philosophical meetings), as these are also a good opportunity for plotting. ${ }^{262}$

The tyrant was envious and suspicious or even terrified for his life and always suspecting his associates of plots. ${ }^{263}$ Sometimes, this is considered the ultimate cause of the tyrant's oppressive measures - it is considered so in Herodotus' Histories, where hybris and envy are seen as the necessary consequence of becoming a tyrant and the cause of the tyrant's crimes. ${ }^{264}$ Either way, the measures the tyrant takes will make him an object of fear and hatred. ${ }^{265}$ This makes the whole situation worse. The tyrant takes excessive precautionary measures like having a taster, wearing armour all the time and being accompanied everywhere by his bodyguard. ${ }^{266} \mathrm{He}$ is so afraid of assassination that he cannot enjoy anything or let his guard down even when he is at home. ${ }^{267}$ His only release is death. ${ }^{268}$

\footnotetext{
255 Arist., Pol., 5.9.1313b 3

${ }^{256}$ Execution at whim is again an early element, already present in Herodotus c.f. Hdt. 3.80.5

${ }^{257}$ Hdt. 3.80.3; 5

${ }^{258}$ Of which the right to be given a trial instead of being executed on the whim of tyrant as described above is certainly included.

259 Arist., Pol., $1313 \mathrm{~b} 1$

260 Arist., Pol., $1313 \mathrm{~b} 3$

${ }^{261}$ Arist., Pol., 1313b 6; Hdt.3.80.4

262 Arist., Pol., 1313a-b

${ }^{263}$ Xen., Hiero, 1.8-10; 6.3-6. For example, Cicero relates that Dionysus was so scared of being assassinated that he only allowed his daughters to shave him, and, even then, only with a piece of coal. (Cicero, Tusculan Disputations, 5.20.58).

${ }^{264}$ Hdt., 3.80.2-3. The story of Croesus, especially, Hdt. 1.34.1.

In tragedy, as we shall see, this is considered the normal reason (along with eulabeia 'caution', its rationalised version), probably to permit a great degree of moralising.

${ }^{265}$ Plato, Resp., 567d

266 Xen., Hiero, 2.8

267 Xen., Hiero, 2.8

268 Xen., Hiero, 7.12-13; Plato, Resp., 567d
} 
The moralising tropes are no less common. Some of these could be seen (and are portrayed as such in Aristotle and Xenophon) as related to rule preservation - for example, the tyrant sometimes had to kill his family members. ${ }^{269}$ This important element occurs in prose as early as Herodotus, who describes how Polycrates killed one of his brothers who had helped him win his tyranny and exiled the other and how Cleisthenes of Sicyon took his tyranny by killing his brother Myron who previously held it. ${ }^{270}$ This is also in Xenophon and Plato's Republic, where the tyrannical man is the sort to harm his parents and kill the people who are his metaphorical children. ${ }^{271}$ There is also the tyrant's temple robbery, which was another way to pay his mercenaries, but had strongly moral content - as is perhaps clear from this trope appearing prominently in Plato, the most moralising of the prose sources. ${ }^{272}$

However, some of the traits are really purely moralising, included to make the tyrant into a moral monster. ${ }^{273}$ One of the major ones is the tyrant's characteristic lack of control (akrolasia). This leads to hybris. ${ }^{274}$ Hybris in particular was an early element that features prominently in Herodotus and then the tragedians. ${ }^{275}$ The tyrant likes flatterers, ${ }^{276}$ or is unpredictable and, as Herodotus writes, likes neither flatterers nor people who refuse to flatter him. ${ }^{277}$ As a result of unlimited wealth and power a tyrant could feast all day (and according to Aristotle some tyrants of his day used to feast in public to show the people that they were happy and prosperous), ${ }^{278}$ and undertake various luxurious excesses such as building opulent palaces and wearing luxurious clothes and symbols of kingship. ${ }^{279}$ The tyrant was also known for having an excess of eros and committing rape and other sexual sins. ${ }^{280}$ Periander is a good example in Herodotus - according to Herodotus, he killed his wife, ${ }^{281}$ then had sex with her corpse. ${ }^{282}$ The tyrant was also known for his cruelty. For

\footnotetext{
${ }^{269}$ Seaford, 2003a, 97: Seaford argues that the moralising traits are also preservative and point out examples from the Histories like Polycrates' seizure of Samos during a festival as proof: 'The typical characteristics of the tyrant are generally represented, in Herodotus, Plato, and elsewhere, as if they were defects of character. But what we can see in the case of Polychaetes is that his impiety, distrust of philoi, and greed all belong to the logic of obtaining and maintaining tyrannical power.'

${ }^{270}$ Hdt. 3.39.2

${ }^{271}$ Xen, Hiero, 3.8; Plato, Resp., 568e-569b; 574a-d

${ }^{272}$ Plato, Resp., 568d. Xenophon also mentions it: Xen., Hiero, 4.11

${ }^{273}$ See Aesch., Eu., 269-272

${ }^{274}$ Arist., Pol., 5.9.1314a 7

${ }^{275}$ For example, in the Constitutional debate: Hdt. 3.80.2-4

${ }^{276}$ Arist., Pol., 5.9.1313b1, Arist., Pol., 5.9.1314a 6; Xen., Hiero, 1.14-15

${ }^{277}$ Hdt. 3.80c

${ }^{278}$ Arist., Pol., 5.9.1314b 14

${ }^{279}$ Xen., Hiero, 11.2

${ }^{280}$ For example, Hdt. 3.80.5. All of the tropes related to lust and sexual crimes go back to Herodotus but are more common in later works.

${ }^{281}$ Hdt. 3.50.1

${ }^{282}$ Hdt. 5.92g 2-3
} 
example, Herodotus says that, in revenge for his son's murder, Periander sent 300 noble Corcyran boys to Alyattes of Lydia to be castrated and turned into eunuchs. ${ }^{283}$

\subsection{Semi-tyrants:}

There are many 'evil' characters in tragedy, only some of whom are tragic tyrants. Most of the examples of 'evil' characters who are not tyrants are women (e.g. Clytaemnestra, Hermione, Medea), but a few of them are kings who do not fit into the type of the tragic tyrant. Evil characters, regardless of whether they are kings or not, are characterised with tyrannical features and, likewise, characters with tyrannical traits are characterised as evil, as immoral behaviour is strongly associated with tyrant tropes.

So, what separates these 'semi-tyrants' and 'bad kings' from tragic tyrants proper? There are two factors - the existence of the polis in the play and the setting of play in the private or public sphere. ${ }^{284}$ As Perris has pointed out, the polis is not ubiquitous in Greek tragedy and some plays are set in a political setting closely based on Homer. Examples of this first situation are the portrayals of Agamemnon and Menelaus in Ajax and Menelaus in Trojan Women - these characters are portrayed negatively, but they are not characterised as tragic tyrants because of the lack of the polis setting - these plays being set plays in the Trojan war. $^{285}$

A large group are not tyrants because their plays have no politics in them (i.e. are centred entirely on the oikos) and their primary roles in the play are not political (i.e. they are chiefly fathers, or husbands, instead of kings). Most Greek tragedy addresses issues within a royal oikos whose conflicts, ${ }^{286}$ as they are royal, naturally have an effect on the wider political community, but in some tragedies, including those with weak tyrannical figures, this effect is downplayed. ${ }^{287}$ Creon from Medea is one potential example of this, even though Perris does explain that his actions would not have been viewed as tyrannical and he would be a weak example of a tyrant anyway because of the mercy he shows to Medea. ${ }^{288}$ Heracles in

\footnotetext{
${ }^{283}$ Hdt. 3.48

${ }^{284}$ A possible exception to this rule is Sophocles' Electra where, as Finglass 2005 and Perris, 2017. As Perris pointed out, the polis isn't present and the play is not otherwise particularly political, but Aegisthus is nevertheless given his usual characterisation as a tyrant who oppresses free speech and indulgences in excessive luxury.

${ }^{285}$ See Perris, 2018

${ }^{286}$ Plays set in the Trojan War (e.g. Ajax, Trojan Women) or otherwise involving relations with different states (E.g. Aeschylus and Euripides' Supplices) are exceptions.

${ }^{287}$ On the other side, the effect of royal quarrels on politics is emphasised in tragedies like Antigone or Heracles furens which do have strongly characterised tyrants.

${ }^{288}$ Compare Oedipus sparing Creon in Oedipus Tyrannus.
} 
Trachiniae is another example: he commits stereotypically tyrannical acts that if he was characterised more strongly as a king and the play was more political or polis-based would be tyrannical. ${ }^{289}$ His murder of his guest friend Iphitus would be a classic example of tyrannical impiety and his enslavement and rape of Iole, when he also sacks her town and murders her family are examples of tyrannical lack of self-control, but the play is primarily focused on the actions of his wife Deianira. Another example of this is Menelaus from Andromache who forces Andromache to break asylum by threatening her son and breaks his oath, allowing his daughter a chance to murder Andromache's son. These are all classic tyrannical characteristics, but since Andromache is set in Neoptolemus' oikos, the polis does not appear in the play and Menelaus primarily appears as Hermione's father, he is not a strong example of a tyrant.

There are other examples where the purpose of giving a character tyrannical features is to leave a mostly 'good' character deserving (at least from the divine point of view) of their fate. For example, Agamemnon in Agamemnon is portrayed as having hubristically gained excessive wealth at Troy by the Chorus and his stepping on the carpet of red garments is also a minor incident of hybris. Both these incidents (as well as his earlier sacrifice-murder of Iphigenia) are portrayed as contributing to his downfall.

\subsection{Tragic tyrants as individuals:}

Before we look at tyrant traits and generalise in order to search for patterns about the nature of tragic tyranny, it is necessary to emphasise that the tragic tyrants are to some degree or another individual characters in different contexts. Therefore, we will briefly introduce the best examples of the tragic tyrants, the 'major' tyrants.

\section{Aegisthus (Aeschylus' Agamemnon and Choephorae, Sophocles' and Euripides' Electra):}

Aeschylus' Aegisthus (in Agamemnon and Choephorae), the earliest example of a tragic tyrant, seems to us to be the model, especially as he is surprisingly well developed in his tyrannical characteristics. Aegisthus' characterisation is pretty synonymous over all three tragedians - he is portrayed as immoral, cowardly and tyrannical with no redeeming features (except in Euripides' Electra where he invites Orestes and Pylades to join him in sacrificing

${ }^{289}$ C.f. Perris, 2017,323 
and feasting). ${ }^{290}$ The Aeschylean Aegisthus is actually a closer model for the utterly evil and unsympathetic tyrants of later works than his successors in Sophocles, Creon and Oedipus.

\section{Oedipus (Oedipus Tyrannus) and Creon (Antigone):}

Oedipus and Creon, more so than any other tragic ruler who can be called a tyrant, are fully fledged characters, who are developed beyond being tyrants and have sympathetic features. As has been pointed out by Lanza among others, the characters are very similar (which is why they are both being discussed here). ${ }^{291}$ Both appear to actually believe in what they are doing, that their actions serve a greater good, instead of viewing their actions as a means to the end of power and kerdos. ${ }^{292}$ Both try to create a moral basis for their leadership, which Oedipus sticks to better than Creon. Contrary to traditional opinion, I do not believe that Oedipus becomes more tyrannical as the play progresses, as I will discuss below.

\section{Zeus (Prometheus Vinctus):}

Zeus, at least in Prometheus Vinctus (we do not know about the lost plays of the trilogy), is pretty much typecast into a standard stock tyrant. However, his lack of presence on stage makes him more of a device for discussing and making pithy statements about the nature of tyranny than is usual with tragic tyrants. He is, however, prevented from turning into a real monster in the style of later tyrants by lack of particularly nasty tyrannical tropes.

\section{Lycus (Heracles furens):}

Lycus is basically a stock tyrant. It is surely not a coincidence, as Lanza has pointed out, that Lycus' name means 'wolf', the same animal that Plato uses in the Republic as a metaphor for the tyrant's rapaciousness. ${ }^{293}$ Of all the tragic tyrants, he is the closest to Plato's monstrous tyrant of the Republic - he is not characterised apart from his tyranny and his tyrannical actions are of the worst kind and highly pragmatic.

\section{Eteocles (Phoenissae):}

Eteocles is similarly characterised to Lycus — by pragmatism and eulabeia. Through his relationship with his mother and because he hasn't actually done anything except usurp the

\footnotetext{
${ }^{290}$ Eur., El., 784-796

${ }^{291}$ Lanza, 1977, 149; 152; Hester, D.A. (1977). “Oedipus and Jonah”, The Cambridge Classical Journal, 23 :

32-61: pp. 39-40

${ }^{292}$ Lanza, 1977, 152

${ }^{293}$ Lanza, 1977, 50
} 
throne of Thebes, he would be a more sympathetic character if it wasn't for his notorious agon speech which characterises him as the worst kind of tyrant, in rhetoric if not in practice.

\section{Creon (Supplices):}

Creon himself is not a great tyrant and suffers from the same problem as the Zeus of Promotheus vinctus because he is not present in the play. However, he is implied to be tyrannical through the speech his herald gives that strongly pits him as a tyrant against the democratic Theseus.

\section{Honourable mention: Pentheus (Bacchae):}

Whether Pentheus can really be considered a major example of tyranny is debatable. Like Eteocles, he is made sympathetic by family relations and like Creon he is humanised (though maybe to a lesser degree) by regretting his actions at the end of the play (instead of dying unrepented like Lycus or Eteocles). Though he does commit some tyrannical actions, what really stops him from being a good example of a tragic tyrant is the lack of politics and discussion of tyranny in his play.

\subsection{Tyrant Tropes:}

Now it is possible to make some generalisations and conclusions on the nature of tragic tyranny by looking at the tropes themselves with examples from the plays.

\section{Illegitimate rise to power:}

With the sole exception of Creon, all of the major examples of tragic tyrants listed above came to power illegitimately. In Herodotus and the political philosophers, the tyrant's rise to power, as we have discussed in earlier in this chapter, takes the form of a coup and demagoguery. Lycus and Zeus are the examples that come closest to the historical and philosophical ideas of the tyrant's rise to power: Lycus made use of stasis in Thebes to kill the former king and take hold of the government but did so peacefully. ${ }^{294}$ Stasis is likewise the cause in Prometheus vinctus, where stasis between the party of Cronus and the party of Zeus leads to Zeus overthrowing Cronus 'by guile' (' $\delta$ ó $\lambda \omega$ ' [Aesch., $P V, 215]$ ), trickery another typical tyrannical road to power. ${ }^{295}$ Aegisthus is the traditional Homeric usurper, ${ }^{296}$ coming to power through an internal coup, his wife's murder of Agamemnon, which he helps

\footnotetext{
${ }^{294}$ Eur., $H F, 132-5$; Lanza, 1977, 115

295 Seaford, 2003a, 98-100

296 Easterling, 1985, 8
} 
orchestrate. ${ }^{297}$ In Phoenissae, Eteocles began as the legitimate king of Thebes, but as he was meant to be ruling in turn with his brother and has not yielded up his throne, by the time the play begins he is ruling illegitimately.

Oedipus is an interesting case. While it can easily be argued that he is a tyrant, whether he is one by illegitimate or at least unorthodox acquisition of the throne is a more complicated question. The theory on Oedipus as a self-made tyrant was first put forward by Knox and then developed by Edmunds and Seaford. ${ }^{298}$ Oedipus did not inherit the throne from his father like a king (as far as he knows), ${ }^{299}$ but was given it as a reward for saving the city of Thebes from the Sphinx. Therefore, at least according to the (barest) technical definition, Oedipus is a tyrannos, a self-made ruler. However, the scenario is, as Lattimore points out, a very traditional mythological idea which may to some degree decrease its significance in characterising the regime of Oedipus. Nevertheless, Oedipus' status as tyrannos is reinforced by the almost exclusive use of the word tyrannos and its cognates to describe him, some of the uses being definitely pejorative, especially $\tau \nu \rho \alpha v v \varepsilon \tilde{\imath} \varsigma$ (Soph., OT, 408) in the agon scene

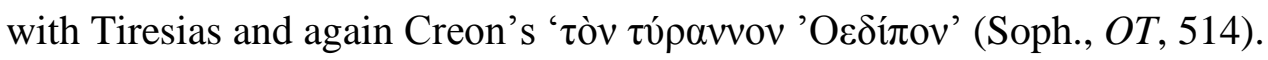

\section{Fear (phobos):}

The tyrant's fear (phobos) of being overthrown encapsulates many sub-tropes and is portrayed as the cause for the tyrant's power-conserving strategies, especially his execution of the best men and the aristocrats and their families (which we will discuss below). The tyrant is terrified of losing his position and therefore he becomes suspicious of the slightest resistance, or even criticism, to his rule. He sees plots everywhere, automatically assuming that everyone is involved in some kind of plot concocted by his real imagined political enemies. ${ }^{300}$ The tyrant's accusations often are aimed at his advisors and there are two different types - direct accusation of political plotting and accusation of bribery.

The ostentatious reasoning for this is summed up well by Oedipus:

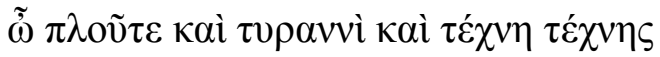

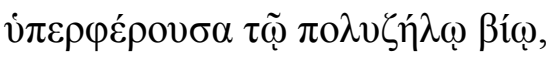

\footnotetext{
297 Aesch., Ag., 1604-1611

${ }^{298}$ Seaford, 2003a, 109; Knox, 1966, 54. Perris calls him 'a strongman who has assumed rule of Thebes' (Perris, 2017, 331).

${ }^{299}$ Knox, 1966, 54-6: 'The terrible truth is that he is king; no man more legitimately' (Knox, 1966, 56).

${ }^{300}$ Accusations of tyranny against the kings themselves are usually true on the other hand.
} 


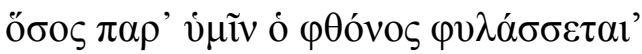

O power, wealth and empire, skill surpassing

skill in this cut-throat world,

how much envy you guard inside you' (Soph., OT, 380-2)

The second reason is the result of this power, i.e. envy (phthonos), which Oedipus here is projecting onto his enemies. Envy was considered by Otanes in Herodotus' Constitutional Debate to be the inevitable result of sole rule. ${ }^{301}$ Jocasta points this out in relation to her sons the tyrant Eteocles and his brother Polyneices, the prospective tyrant. She points to phthonos as a trait of both the brothers, who unlike the sun and the moon are envious of each other's power: ${ }^{302}$

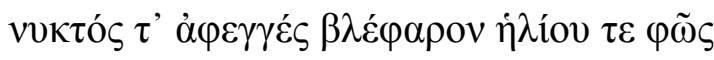

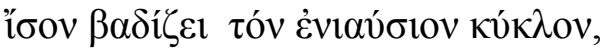

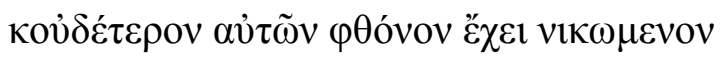

The dark eye of night and the light of the sun

Walk equally their yearly cycles,

And neither of them is envious of the other once conquered. (Eur., Phoen., 544-6)

Thirdly, the fear can be cause or result of the tyrant's cowardice (anadria), which is particularly a characteristic of Aegisthus, who did not fight in the Trojan War, as the Chorus of Agamemnon points out: ${ }^{303}$

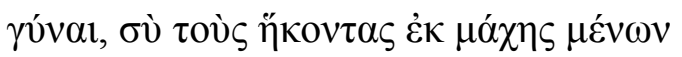

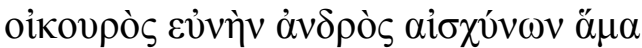

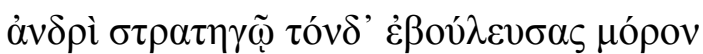

Woman, you stay-at-home, who waited for the men to come back from battle

While dishonouring the bed of a real man,

\footnotetext{
301 Hdt., 3.80 .3

${ }^{302}$ Lanza, 1977, 236

${ }^{303}$ C.f. also Eur., El., 917, 930-1, 948-9, which will be discussed in more detail later.
} 
How did you plot the death of a man and a general? (Aesch., Ag., 1625-7)

Aegisthus is even given the epithet analkis, 'impotent', 'feeble', ${ }^{304}$ in both Sophocles and Aeschylus. ${ }^{305}$ The connection between fear and cowardice is more explicit in Euripides' Electra with Aegisthus worrying about Orestes and Electra rising up against him but more so with the example of Lycus or Eurystheus trying to kill the Heraclids which we will discuss below. ${ }^{306}$

Related also is the tyrant's tendency towards rashness and to jump to conclusions. This can be seen in all of the examples below, but especially with Oedipus in Oedipus Tyrannus, when he accuses Creon of plotting against him. ${ }^{307}$

Tyrants often fear the most and are the most suspicious of advisor characters, that is characters who are in some position to give advice to the tragic tyrant (for example, Tiresias or the tyrant's philoi). The wider trope of mistrusting or disregarding advisor characters is fairly common - it happens with Pentheus and Tiresias in Bacchae, Creon and Haemon in Antigone. The more specific trope of the tyrant accusing advisor characters of conspiracy occurs with Zeus and Prometheus in Prometheus Vinctus and prominently with Creon in Antigone and Oedipus in Oedipus Tyrannus.

The tyrant is suspicious that some characters, most of them advisors, are plotting to replace him. Usually, these are advisor characters, for example, in Episode One, when Tiresias is uncooperative, Oedipus accuses Tiresias and Creon of being involved with Laius' murder:

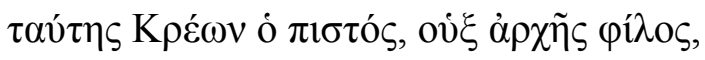

\footnotetext{
${ }^{304}$ LSJ, óv $\alpha \lambda \kappa ı \varsigma$

${ }^{305}$ Earlier in Agamemnon, Cassandra says:

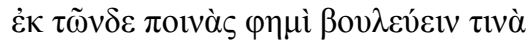

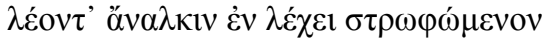

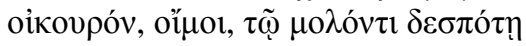
$\dot{\varepsilon} \mu \tilde{\omega}:$

For this, I say that a feeble, stay-at-home Lion, occupying my master's bed,

Plots against him, alas. (Aesch., Ag., 1223-6)

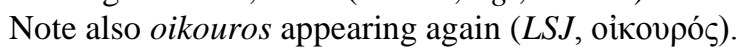

At Soph., El., 301-2 Aegisthus is described as and needing a woman to fight for him.

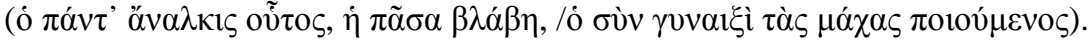

${ }^{306}$ Eur., El., 16-24

${ }^{307}$ C.f. Soph., OT, 523-4; 634-641
} 


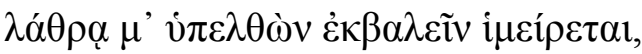

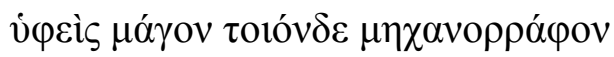

For this [tyranny], Kreon the trustworthy, my friend from the beginning,

Creeping up on me, secretly longs to overthrow me,

Engaging this scheming mage (Soph., OT, 385-7) ${ }^{308}$

In Prometheus Vinctus, the plot surrounds this particular tyrant trope - Zeus punishes his advisor Prometheus even though Prometheus helped him win his throne. ${ }^{309}$ Prometheus complains about this directly:

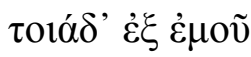

ó $\tau \tilde{\omega} v \theta \varepsilon \tilde{\omega} \nu \tau u ́ \rho \alpha v v o \varsigma ~ \omega ̉ \varphi \varepsilon \lambda \eta \mu \varepsilon ́ v o \varsigma$

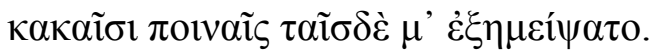

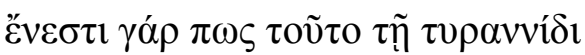

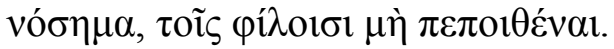

Though the tyrant

of the gods was helped by me,

He repaid me with these evil punishments.

For somehow this is a disease in tyrants,

Not to trust their friends (philoi). (Aesch., PB., 223-227) $)^{310}$

The tyrant can also be suspicious of other characters. Before centring his accusations on Creon and Tiresias, Oedipus assumes that Laius was murdered by bandits paid off by

${ }^{308}$ C.f. also Soph., OT, 346-8; 378

${ }^{309}$ Aesch., PB, 219ff.

${ }^{310}$ See also Aesch., PB., 306-8:

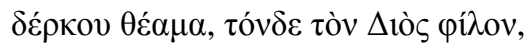

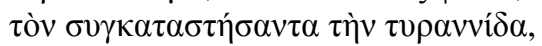

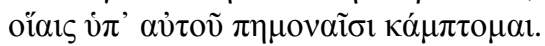
See this sight, I who was a friend of Zeus, Who helped him set up his tyranny, Am bent over with miseries because of him. 


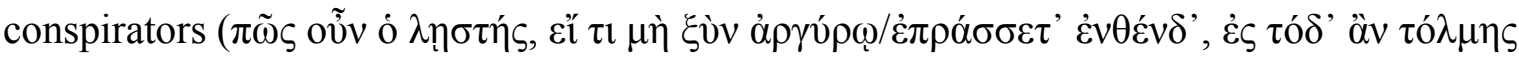
$\varepsilon \beta \eta[$ Soph., $O T, 124-5])$ and that whoever was responsible might target him next. ${ }^{311}$

Likewise, in Antigone, Creon thinks men unhappy with his rule have conspired to bury Polyneices' body:

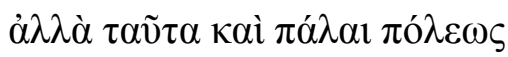

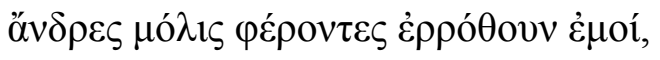

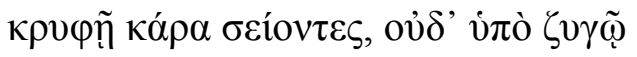

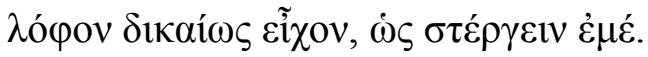

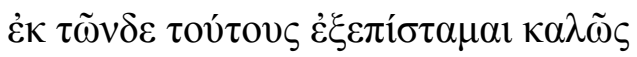

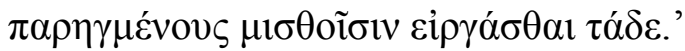

'But, from the start, men of the city,

Scarcely bearing my rule, clamoured against me in such a way,

Shaking their heads in secret, not rightly keeping

their necks under the yoke, to satisfy me.

I am completely sure that these men were led

By those men to do it with bribes.' (Soph., Ant., 289-294)

Creon also accuses Antigone and Ismene of plotting against him, calling them 'two ruins

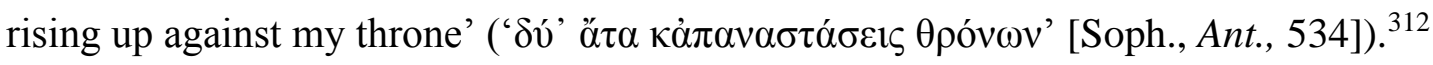

The tragic tyrant is also prone to suspicion that people are being bribed to overthrow him. Creon accuses the guards of taking bribes from his political enemies to bury Polyneices:

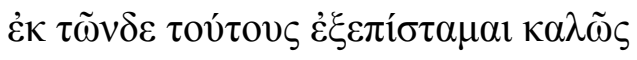

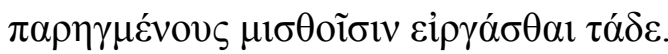

I am completely sure that these men were led 
By those men [the conspirators mentioned above] to do it with bribes. (Soph., Ant., 293-294)

This is followed by a more general tirade on the corrupting power of money:

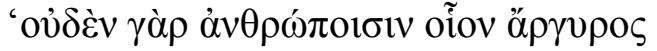

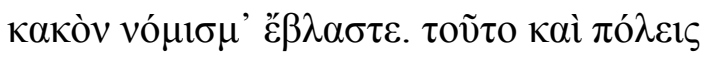

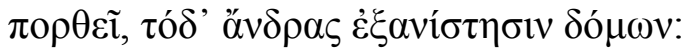

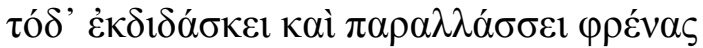

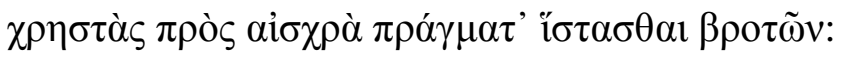

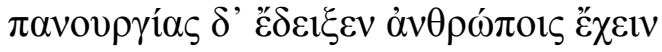

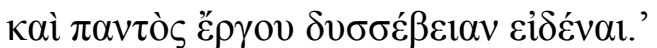

'For no custom has sprung up among men

As evil as money. And this razes cities

This tears men from their homes:

This trains and twists the good minds

To create shameful deeds among men:

And it brings to light villainy among men

And knows impiety in every deed.' (S. Ant., 295-302)

A specific form of suspicion of bribery is the 'mercenary seer' sub-trope in which Tiresias is accused of prophesising for kerdos. Oedipus assumes that Tiresias has been convinced by Creon to give false prophecies for the sake of kerdos, and is a:

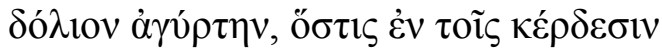

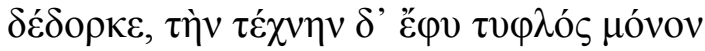

'A deceitful vagabond, who sees only

In terms of profit, blind to his art.' (Soph., OT, 388-9) 
This mercenary seer theme is also seen in Antigone when Creon accuses Tiresias of kerdos, ${ }^{313}$ and is especially emphasised at 1034-6:

$\kappa o u ̉ \delta \grave{\varepsilon} \mu \alpha \nu \tau \imath \kappa \tilde{\eta} \varsigma$

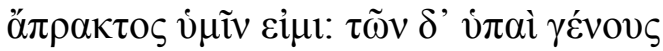

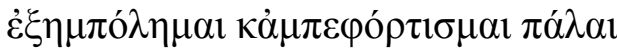

"And I am not unassailed

by your prophetic arts: but I have long been bought

And sold and loaded up by your lot."314

Eulabeia, caution, is the rationalised version of the tyrant's phobos - thus it is more present in the highly developed and more negatively portrayed tyrants. ${ }^{315}$ Lycus in Heracles illustrates this concept perfectly, using eulabeia to explain why he wants to kill the Heraclids, just in case they return to revenge their grandfather: ${ }^{316}$

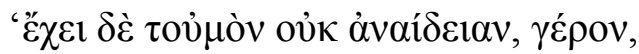

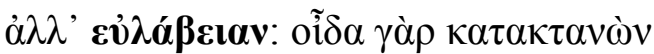

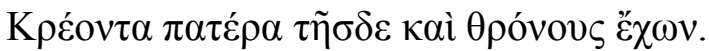

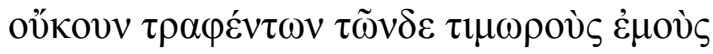

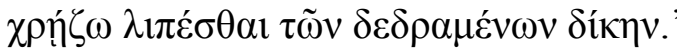

'My reason is not cruelty, old man,

But caution: for I know I killed

Creon, the father of this woman, and hold his throne.

So I do not wish to leave unharmed my avengers, since these

Boys, grown up, will take vengeance.' (Eur., $H F, 165-9)$

\footnotetext{
${ }^{313}$ Soph., Ant., 1033-1047

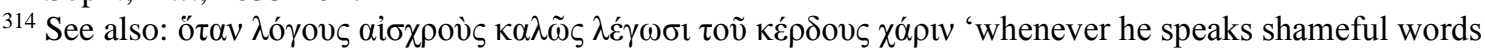
nicely for the sake of profit' (Soph., OT, 1046-7). Kerdos and its relatives also occur twice in this speech alone:

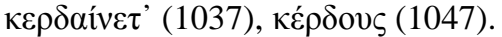

${ }^{315}$ Lanza, 1977, 46-7; 112-114

${ }^{316}$ Lanza, 1977, 46-7
} 
Eulabeia is the tyrant's aid in conserving his throne, which he can lose if he does not take the right precautions. This is made obvious in Phoenissae, when Eteocles calls upon the personification of eulabeia to help him defeat the Argives:

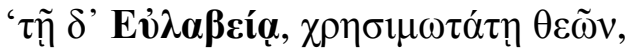

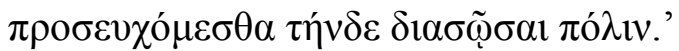

'We will pray to Caution, the most expedient of goddesses,

to save our city' (Eur., Phoen., 782-3). ${ }^{317}$

The constant fear that the tyrant endures has the power to make him miserable despite his power and wealth. Euripides' Aeschylus is described as so scared he is unable to sleep. ${ }^{318}$ Oedipus himself confirms it with his speech on the dangers of Wealth and Tyranny quoted above and petulantly states he never wanted the tyranny anyway. As Edmunds points out, in Creon's agon speech to Oedipus, Creon gives his reasons why he wouldn't want to be a tyrant in terms of negative aspects of tyranny, arguing along the lines of Plato and Xenophon that the tyrant is miserable. ${ }^{319}$ Creon does not want to be tyrant because he would rather

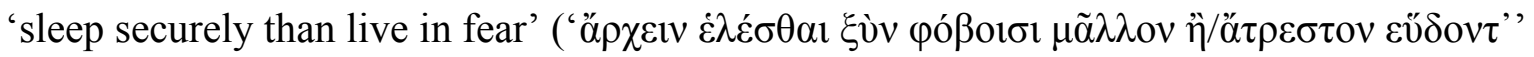

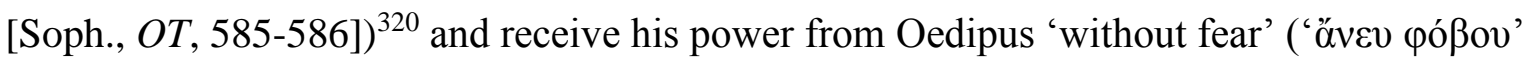
[Soph., OT, 590]) which implies that Oedipus, like the conventional tyrant, is unpopular enough to fear assassins and conspiracies so much he cannot sleep at night. Creon also wants

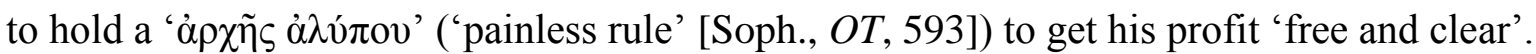
While these statements could have innocent meanings of not wanting to do ceremonial duties of the king like making sacrifices and judging disputes, they also could refer to the unsavoury measures that Hiero in Xenophon's Hiero complains the tyrant must take to keep his position: killing or exiling one's political enemies, any men of worth in the state and conspirators.

\footnotetext{
${ }^{317}$ Lanza, 1977, 46-7; 140

318 Eur., El., 617

${ }^{319}$ Creon is correct in that it is true that Oedipus is a tyrant and Oedipus does have a paranoid fear of conspiracies, however, this fear is not justified by anything Oedipus has done.

320 ó $\tau \rho \varepsilon \sigma \tau o v$, 'fearless', 'without trembling' has a connection with fear because it come from $\tau \rho \varepsilon \varepsilon^{\omega}$ 'fear'.
} 


\section{Precautionary/power-saving measures:}

To keep hold of his throne and to keep his fear at bay, the tragic tyrant undertakes a variety of precautionary measures. Tropes like warmongering, populism, freeing slaves and building projects and rarer precautionary methods (such as wearing armour) are usually absent. The tragic tyrant is usually portrayed as not accountable for his actions. Most significant, however, is his use of force (bia) erode his subjects' rights-primarily in tragedy, the rights of freedom of speech and the right to life. The consequence of these measures is the tyrant is an object of fear.

The tyrant may have a mercenary bodyguard to protect him and preserve his rule. The mercenary nature of this guard is not always confirmed, ${ }^{321}$ but we can assume that is the case from statements made in Aristotle. This is not a common feature of the tragic tyrant, yet does occur in portrayals of Aegisthus. In Agamemnon, Aegisthus mentions that he will keep his

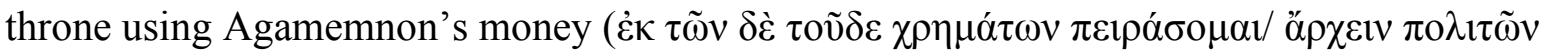
(Aesch., Ag., 1638-9), presumably to pay his mercenary guard, and the guard itself is used to threaten the Chorus for their dissent. ${ }^{322}$ In Electra, Aegisthus has a bodyguard and Orestes has to wait until he is sacrificing unguarded to kill him. ${ }^{323}$

The tyrant will use force (bia) to conserve his power. Nowhere is this clearer than in the beginning of Prometheus Vinctus where Force (Bia) and Power (Kratos) are the literal as well as figurative enforcers of the tyrant Zeus' will. Lycus is another example, ${ }^{324}$ with Amphytrion

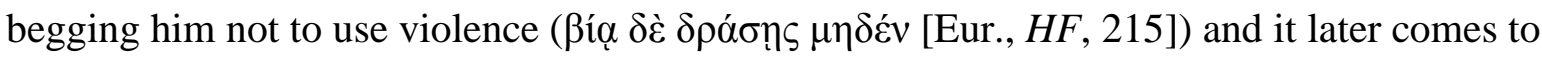
light that bia has already been used, when Megara explains Heracles how his family came to be in the temple:

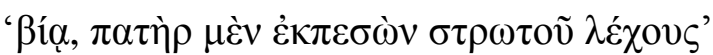

'By force, your father torn from his covered bed' (Eur, $H F, 555)$

\footnotetext{
${ }^{321}$ In Euripides' Electra, the bodyguard is made up of slaves (specifically, domes, war captives, presumably from the Trojan war [LSJ, $\delta \mu \omega ́ \varsigma])$ :

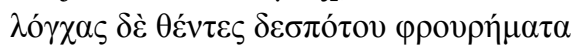

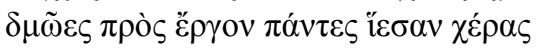

And the slaves of the master's [Aegisthus'] bodyguard, laying down their spears,

Hastened all hands to the task (Eur., El., 798-9).

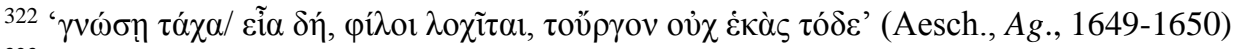

${ }^{323}$ Eur., El., 615-633; 798

${ }^{324}$ Lanza, 1977, 111-2
} 
The tyrant's use of force at his will was considered as depriving the citizens of their rights. The types of force used - execution, torture and beating - all had their legal place in Ancient Greek society, for example in beating or torturing slaves. Therefore, emphasis is placed on the illegality of these actions in tragedy: they are deeds of a tyrant (as opposed to a legitimate and accountable magistrate) against free citizens who in Classical Athens would be given the rights to a fair trial and exile. The tyrant is unaccountable (aneuthunos) for his actions and can do what he wants - a characteristic that is emphasised as tyrannical by Otanes the Constitutional Debate and Polus in Plato's Gorgias. ${ }^{325}$ This is clear in tragedy mostly from the sort of highly unconstitutional behaviour (such as summary execution) tragic tyrants can get away with-examples like Lycus in Heracles, Pentheus in Bacchae, Creon in Oedipus at Colonus, and Menelaus in Andromache clearly believe that they can do whatever they want regardless of how bad it is.

The tyrant's lack of accountability (his being aneuthunos) is often seen in prose in the form of disobeyed laws or making new ones based solely on his own authority. This is not as common in tragedy as other forms of being aneuthunos, however there is one prominent example-in Antigone, when Creon decrees that he will execute whoever is caught burying Polyneices' body. ${ }^{326}$ His use of kerugma, decree, makes this sound more formal, like a decree of the demos in Athens, but the reality is this is an arbitrary command of a tyrant (Creon himself even describes it as his own phonema, will [Soph., Ant., 208]) and not based on any laws of the state. ${ }^{327}$ Later in his agon speech to Haemon, Creon also expresses this attitude that rulers should be obeyed regardless of their orders:

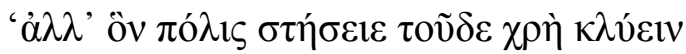

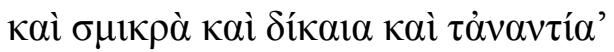

'Rather he who the city sets up must be obeyed

in both small and just things and their opposites, large and unjust things' (Soph., Ant., 666-7)

\footnotetext{
${ }^{325}$ Lanza, 1977, 233, 235

${ }^{326}$ Soph., Ant., 192-206. For both Creon and Oedipus, there is an assumption by other characters that they will be responsible for their actions.

${ }^{327}$ See Soph., OT, 191-3, 204-5
} 
This is related to the trope of the tyrant assimilating himself with the city. Again, this is prominently displayed by Creon in his agon scene with Haemon. ${ }^{328}$ It appears more prominently in Oedipus Tyrannus, when Creon comes close to suggesting that Oedipus may not be the best ruler of Thebes: ${ }^{329}$

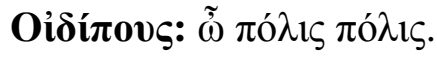

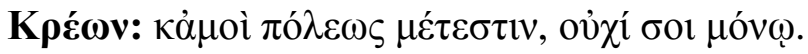

Oedipus: O city, city!

Creon: I have a share in the city too, not just you. (Soph., OT, 629-639)

The tyrant's use of arbitrary execution usually fits into the trope of the tyrant's murdering of political enemies and the best men (aristoi) of the city though not as often as in Herodotus. Apart from the example of Antigone, we also see this in Oedipus Tyrannus when Oedipus decides to kill Creon, telling him 'I want you dead, not exiled' ( $\theta v \underline{\sigma} \sigma \kappa \varepsilon ı v$, oủ $\varphi v \gamma \varepsilon \tilde{v} v \sigma \varepsilon$

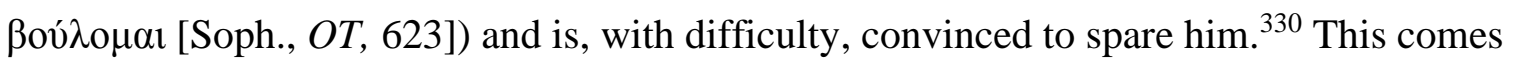
under this trope because, as Creon points out, he and Jocasta are second in command to Oedipus. ${ }^{331}$ In the Bacchae, Pentheus threatens to have the disguised Dionysus stoned and beheaded. ${ }^{332}$ Aegisthus, together with his wife Clytaemnestra, has Agamemnon killed and is narrowly prevented from killing Orestes. ${ }^{333}$ Most of the examples involve individuals, with the exception of trying to kill one's enemy's children and in Aeschylus' Agamemnon where Aegisthus nearly orders his guards to kill the Chorus. ${ }^{334}$ Out of the examples concerning murdering one's enemy's children, the example given above from Heracles of Lycus' reasoning for killing the Heraclids is a straightfoward one. ${ }^{335}$

\footnotetext{
${ }^{328}$ Soph., Ant., 734-740; Cerri, 1982, 148-9; Lanza, 1977, 157. Lanza also gives Eteocles as an example of a tyrant who equates his own benefit with that of this city (Lanza, 1977, 139).

${ }^{329}$ Soph., OT, 627-9

${ }^{330}$ Soph., OT, 402-3; 669-676

${ }^{331}$ Soph., OT, 581

${ }^{332}$ Eur., Bach., 355-7; Eur., Bach., 232

${ }^{333}$ C.f. for example, Eur., El., 16-7. In Clytaemnestra's case, this is the more serious crime of murder of philoi, and also technically in Aegisthus' case because he is the cousin of Agamemnon and Orestes' stepfather/secondcousin. However, this kin-relationship is never emphasized in the play.

${ }^{334}$ Aesch., Ag., 1649-1653

${ }^{335}$ Eur., $H F, 165-9$
} 
Use of beatings and torture by the tragic tyrant is not as common but it does occur. In Antigone, Creon threatens the guard with execution and torture if he does not find out who buried Polyneices:

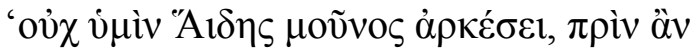

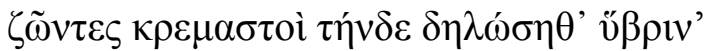

'Hades alone will not suffice for you, before

You have been hung alive as an example of this violence.' (Soph., Ant., 306-9)

In Agamemnon, Aegisthus threatens to torture the Chorus three times within thirty lines twice with chains and starvation, ${ }^{336}$ and once, ${ }^{337}$ or maybe twice, ${ }^{338}$ with beatings.

The tragic tyrant is also portrayed as suspending other conventional rights afforded to Athenian citizens - the rights to freedom of assembly, action, movement and the right to freedom of speech (parrhesia) - and even their very status as eleutheroi, free men. All except the denial of parrhesia are not particularly common in tragedy. ${ }^{343}$ Suppression of freedom of movement and action is not common - the most obvious examples are Creon's execution of Antigone and Zeus' punishment of Prometheus for giving fire to man.

Suspension of parrhesia, on the other hand, is an almost ubiquitous element among the major tyrants. As seen in the examples above, Agamemnon's Aegisthus threatens the Chorus with torture and beatings if they speak out against his regime. It can be seen in Antigone, from the guard's behaviour, that he is afraid to even tell Creon of Polyneices' burial. ${ }^{344}$ Antigone accuses Creon of suppressing the parrhesia of the Thebans who actually believe her side of the argument:

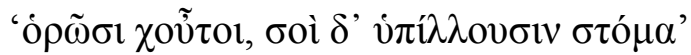

'They see it, but for you they keep their mouths closed.' 345

\footnotetext{
${ }^{336}$ Aesch., Ag., 1621-1623; 1639-42

${ }^{337}$ Aesch., Ag., 1631-2

${ }^{338}$ Aesch., Ag., 1621-1623

${ }^{343}$ Being free and a citizen in Athens meant the ability to act and speak as one liked. C.f. Lanza, 1977, 78-9, the example of the democratic animals in the Republic (Plato, Resp., 563c) and the Old Oligarch (Ps. Xen., Ath. Pol., 1.10-12).

344 Soph., Ant., $223 \mathrm{ff}$.

345 This is confirmed by Haemon in lines 690-700, especially:
} 
A very clear example is Lycus' threat to the Chorus, pointing out both the dangers of parrhesia under his regime:

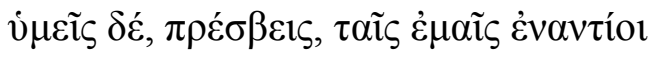

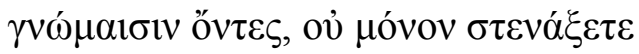

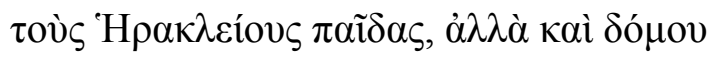

$\tau u ́ \chi \alpha \varsigma, ~ o ̋ \tau \alpha v \pi \alpha ́ \sigma \chi \eta \tau \ldots$

And you, old men, as you oppose

My views, you will not sigh deeply

For the sons of Heracles alone, but for the fate

Of your own house, when you suffer...' (Eur., HF, 247-250) (346 $^{346}$

Another example is Tiresias in his agon speech feeling the need to assert his right to reply

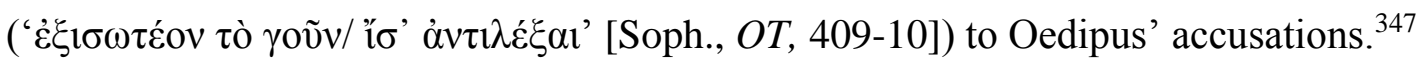

There is the possibility that some tragic tyrants go further in their quest of suppressing parrheisa than mere use of force - by employing informers, a common feature of Eastern courts, or spies. It may be being implied in Euripides' Electra that the Argives are too scared to make libations or offerings on Agamemnon's grave because Aegisthus has spies who will find them out (or this is another example of supressing freedom of movement and they are just afraid of his guards):

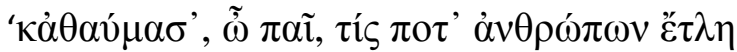

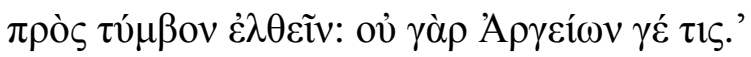

'And I wondered, child, whoever among men dared

To go to the tomb: for it was not any of the Argives' (Eur., El., 516-7)

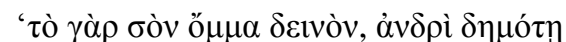

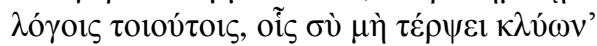

'for the man of the people who uses such words,

which you hearing would not delight in, your gaze is terrible.' (Soph, Ant., 690-1)

See also Soph., Ant., 733; and Griffith, 1999, 56, n. 163 and Middle Liddell vं $\pi \dot{\lambda} \lambda \lambda \omega$.

${ }^{346}$ C.f. also Eur., $H F, 277-8$

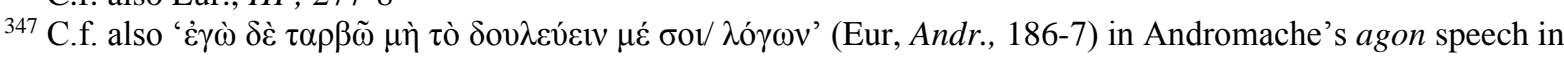
Andromache. 
Likewise, Creon imagines the conspirators plotting in secret because they are afraid of spies. However, it could just be that their parrheisa is so inhibited that they cannot air their grievances with Creon. ${ }^{348}$ The potential use of spies seems highly anachronistic, as they are not mentioned in prose before Aristotle.

The repression of the fundamental right of eleutheria, freedom as opposed to servitude, is also seen in tragedy. This is a trait and theme that is common in Herodotus and Plato tyranny is such a state of oppression that it is like the tyrant is a master and his subject his slaves - they do not have the rights of a free men (an eleutheros): parrhesia or a say in the running of their polis, and the tyrant has the power of life and death over them. ${ }^{349}$ Tyrannis and eleutheria are ideological opposites, both morally and politically. ${ }^{350}$ The best example of this trope in tragedy is the ending of Lycus' warning to the Chorus that was quoted above:

' $\mu \varepsilon \mu \nu \eta ́ \sigma \varepsilon \sigma \theta \varepsilon \delta \grave{\varepsilon}$

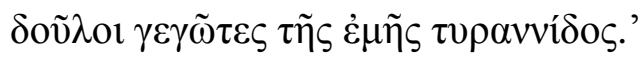

'...you will remember

That you are the slaves of me, your tyrant.' (Eur., $H F, 250-251)^{351}$

Creon also portrays this trope at the beginning of his speech in his agon with Antigone, when, in the third of several metaphors for subjugation of unwilling materials (symbolising Antigone), he finishes with:

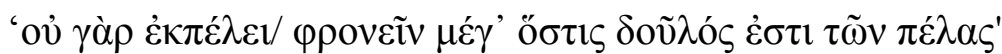

'For anyone who is the slave of his neighbour cannot think great thoughts.' (Soph., Ant., 479)

Again, Eteocles evidently believes that tyranny is a state of slavery when in his agon speech

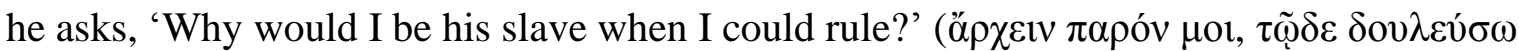
$\pi$ o $\varepsilon^{\prime}$; (Eur., Phoen., 520), making the implicit contrast between ruling (i.e. as a tyrant) and being a slave (i.e. being a subject). Another example is Aegisthus' treatment of the Chorus at the end of Agamemnon. ${ }^{352}$

\footnotetext{
${ }^{348}$ Soph., Ant., 289-291

${ }^{349}$ Lanza, 1977, 71-4

${ }^{350}$ Lanza, 1977, 84

${ }^{351}$ C.f. also Eur., $H F, 277-8$

${ }^{352}$ Especially Aesch., Ag., 1617-8; 1639-41
} 
The consequences of all these repressive measures is the tyrant is feared, which may protect him from being overthrown. This is seen in many places, but the strongest examples are in Antigone, in the guard's fear of Creon, ${ }^{354}$ and the references to the Chorus and populace being too afraid of Creon to speak mentioned above. ${ }^{355}$

\section{Injustice (adikia):}

Injustice (adikia) is an umbrella trope that covers many behaviours that tyrants were said to commit (and so many other tropes). Lanza believes that injustice was primarily a type of impiety, classifying it under asebeialdussebeia. ${ }^{356}$ This view has validity, as justice, dike, was personified as the goddess Dike, the daughter of Zeus, who was also heavily associated with justice. ${ }^{357}$ However, adikia, like dike, clearly has associations that are not directly linked to piety. Adikia, and its cognates, adikeo and adikos, cover a wide range of immoral behaviour which includes the tropes of the tyrant's coup, treating supporters and friends badly, depriving the people of their rights, execution of dissidents, greed for power and money, murder of philoi and xenoi, breaking oaths, hybris and also the more concrete forms of impiety_killing suppliants, destroying or robbing temples and disrespecting custom or natural laws. ${ }^{358}$ An example of another trope as adikos is Electra in Euripides' Electra describing Aegisthus' adultery with her mother-'though you were doing wrong to my

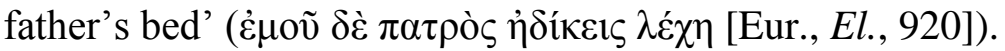

The idea of the tyrant as unjust simply by being a tyrant is clearly seen in Euripides' Phoenissae, where Eteocles himself suggests that 'it is best to do wrong for tyranny' ( tyranny as a breach of adikia. A few lines later his mother, Jocasta, says something similar, that the goddess Philotimia, Ambition, is unjust:

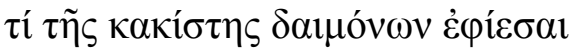

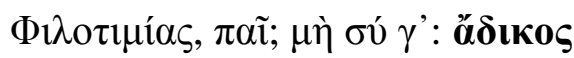

Why, son, do you desire the worst of goddesses,

\footnotetext{
${ }^{354}$ Soph., Ant., $223 \mathrm{ff}$.

${ }^{355}$ Another example is in Euripides' Electra where no one would come to Agamemnon's grave because of fear

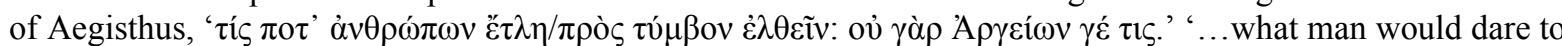
come to the grave: for it was definitely not one of the Argives'. (Eur., El., 516-7).

${ }^{356}$ Lanza, 1977, 234

357 One of Zeus' epithets was dikaios.

${ }^{358}$ C.f. Aesch., Eu., 269-72, quoted below.
} 
Ambition? You shouldn't: that goddess is unjust (Eur., Phoen., 631-2)

She goes on to describe the quest for tyranny as adikia. ${ }^{359}$ This is of course, a common enough idea in tragedy. ${ }^{360}$

The trope of disrespecting custom and natural law is often associated with adikia. In tragedy, custom (nomos), is conflated with divine or natural law because of the associations of custom with piety, so disrespecting customs is seen as disrespecting the laws of the gods which cannot be broken without incurring the wrath of Dike and Zeus. Both the examples of tyrants committing this form of injustice in tragedy are concerned around the burial of the dead by Creon after the attack of the Seven and their army, in Antigone and Euripides' Supplices. The most famous example comes from the first agon scene in Antigone, where Antigone explains the difference between divine and human law - divine law is eternal and the penalties for

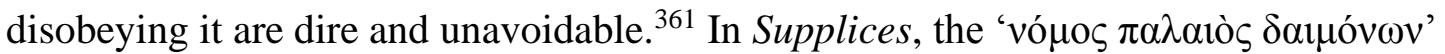
'ancient law of the gods' (Eur., Supp., 563) of burying the dead is used as Theseus' casus belli for the Athenians to attack Thebes. ${ }^{362}$

\section{Moralising tropes:}

The major examples of tragic tyrants also contain plenty of traits included more for moral commentary. Broadly these can sorted into two categories - tropes relating to lack of selfcontrol (anger, lust, greed etc.) and tropes relating to impiety (blasphemy, murder of philoi, hybris etc.). These traits sometimes have little to do with ruling, but are more related to the tyrant's personality - like the tyrannical man in Plato's Republic, they show the sort of men the tyrants are: monsters characterised by lack of sophrosune (i.e. lack of self-control) that borders on madness, ${ }^{363}$ as well as disrespect for fundamental Greek values such as eusebeia, xenia and philia.

\footnotetext{
${ }^{359}$ Lanza, 1977, 235. C.f. Also Eur., Phoen., 548-9 where Jocasta complains that Eteocles' monopoly on the

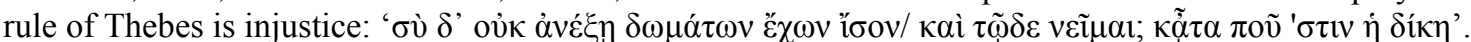

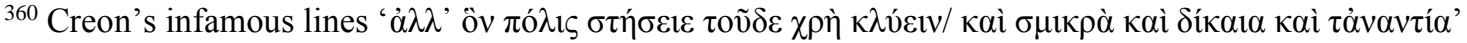
'Rather he who the city sets up must be obeyed in both small and just things and their opposites, large and unjust things' (Soph., Ant., 666-7) are another example of this.

${ }^{361}$ Soph., Ant., $450-460$

${ }^{362}$ Eur., Supp., 514ff. Eteocles' phusis versus nomos argument is another example of injustice (or a celebration of living without justice).

${ }^{363}$ Lanza, 1977, 85-93
} 


\section{Lack of self-control (akrolasia):}

One of the common umbrella tropes in this category is lack of self-control, or akrolasia, ${ }^{364}$ a category that has little to do with ruling. Several manifestations of this - namely lust, luxury and gain (kerdos) — have their own sub-tropes. Of the rest, anger (orge/cholos) is the most common. Cruelty, which along with luxury and some sub-tropes of lust (especially rape) is one of the newer tropes which are more common after tragedy, also appears, as does (desire for) flattery. Madness is one trope which later becomes a major part of the tyrant (and is present in Herodotus' Cambyses) which is not to any real degree present in tragic tyrants.

Anger (orge/cholos) towards the tyrant's subjects is the most common even in lesser examples of tragic tyranny. ${ }^{365}$ Pretty much all of our major examples contain this. Oedipus gets angry at Tiresias and Creon as the former points out several times. ${ }^{366}$ Creon gets angry at everyone he comes across. ${ }^{367}$ Also present is a sub-trope of the tyrant's anger, the 'flashing

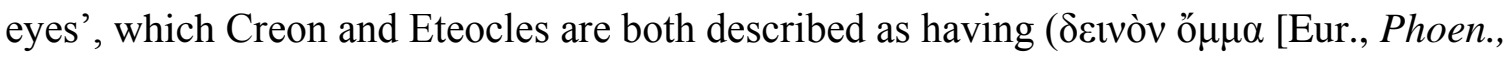

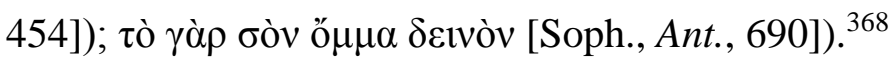

The tragic tyrant can be prone to cruelty though this is less common than in Herodotus or later historians. Above, we looked at examples of tragic tyrants threatening to kill, torture or beat their subjects, which would qualify for this trope. Special examples where the tyrant seems to take pleasure in this instead of just using it as a means to an end, however, include Lycus' attempt to kill the Heraclids.

The tyrant's craving for flattery is also another element of his lack of self-control. It is not particularly prominent in tragedy, and the closest thing that really exists is the Chorus and Jocasta's efforts not to convince Oedipus not to execute Creon, ${ }^{369}$ or parts of the agon scene between Creon and Haemon in Antigone. ${ }^{370}$

\section{Lust:}

The lack of control over lust and committing sexual crimes seen in Herodotean and later prose tyrants are less common in tragic tyrants. In tragedy, adultery, incest, rape and

\footnotetext{
${ }^{364}$ Lanza, 1977, 49, 234

${ }^{365}$ Lanza, 1977, 49-50

${ }^{366}$ Lanza, 1977, 50-1; E.g. Soph., OT, 357-8, 365, 673-4.

${ }^{367}$ Lanza, however, points out his speeches are surprisingly calm (Lanza, 1977, 153-7).

${ }^{368}$ Lanza, 1977, 50: This was originally a Homeric epithet.

369 Soph., OT, 616-7; 631ff

${ }^{370}$ Soph., Ant., 635-8; 701-4
} 
effeminacy are very rare and we do not see other forms of sexual perversion such as anal sex or necrophilia. In fact, the lust tropes are so insignificant in our corpus of extant plays that they would not be significant at all if the tropes weren't so common in later depictions of tyrants. Aegisthus the sole example for nearly all these sub-tropes. In particular, his traditional role as an adulterer becomes part of his characterisation as a tyrant. $\mathrm{He}$ is the only example of adultery and also the only example of rape and effeminacy in a tragic tyrant. ${ }^{371}$ Euripides, in Electra, characterises Aegisthus as a seducer and rapist and as overly pretty (i.e., effeminate):

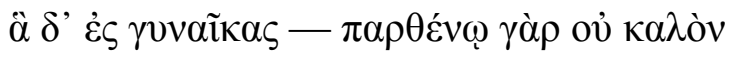

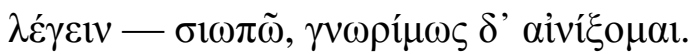

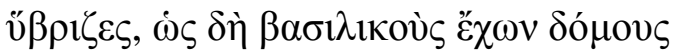

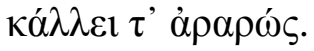

And as for your women-for it is not good for a maiden

To speak of -I will keep quiet, I will speak in well-known riddles.

You took liberties with women, as you had the palace of a king

And were furnished with beauty. (Eur., El., 1945-8) ${ }^{372}$

Oedipus provides the sole example of incest, which is still significant even though it was accidental. $^{373}$

\section{Luxury:}

The same statement applies to luxury in tragedy as does to lust: the trope's appearance is so slight that it only has significance in view of later portrayals. Sophocles' and Euripides' Aegisthus is also the only example of a tragic tyrant to show examples of luxury - general luxury, wearing purple clothing and excessive drinking (banqueting does not occur). Sophocles' Electra mention that Aegisthus indulged in luxury, squandering Agamemnon's money but does not give us any details:

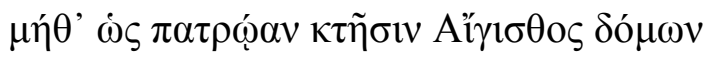

\footnotetext{
${ }^{371}$ However, Heracles in Trachiniae rapes his prisoner Iole.

${ }^{372}$ Lanza, 1977, 118

${ }^{373}$ Also, as Hester points out, intention was not as a large a factor in guilt in Ancient Greek thought as it is considered today (Hester, 1977, 34).
} 


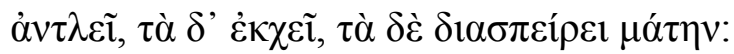

'Nor how Aegisthus' squandered the wealth of our father's

house, whether wasting it or scattering it around randomly.' (Eur., El., 1290-1)

Something similar focusing on Clytaemnestra's clothes is said in Euripides' Electra. ${ }^{374}$

However, the only potential evidence of a tyrant character dressing "tyrannically" is

Aegisthus wearing Agamemnon's robes in Sophocles' Electra. ${ }^{375}$ Euripides' Electra also has Aegisthus drinking-Electra says he often jumps on Agamemnon's grave while drunk and pelts it with his fists. ${ }^{376}$

\section{Gain (kerdos):}

(Desire of) gain or profit (kerdos) is another form of lack of self-control which encompasses enough material to be an umbrella trope with its own related tropes. ${ }^{377}$ Seaford classifies it as rule-preserving because the tyrant needs money to pay the mercenaries who keep him in power. ${ }^{378}$ While that may be true, kerdos is primarily a moral trait and part of the tyrant's lack of self-restraint. Kerdos is always portrayed as a bad thing in tragedy, synonymous with aischrokerdia, shameful love of gain, excessive greed and getting of money from bad sources, and as such a potential and actual characteristic of the tragic tyrant. Kerdos has roughly two forms of sub-trope in tragedy, desire for money and desire for power, but desire for money does not appear prominently among tragic tyrants. ${ }^{379}$ Other tropes related to this that appear in Herodotus and Plato - robbery and plunder (harpage), confiscation of one's enemies' property and killing rich men for their money, do not appear as traits for tragic tyrants.

Greed for money does not actually seem to be as common a feature of tragic tyranny as it is often considered by modern scholarship. ${ }^{380}$ Lanza and Seaford believe that Creon's and Oedipus' obsession over each other's kerdos is a reflection of their own, showing that they

\footnotetext{
${ }^{374}$ Eur., El., 314-322; 965.

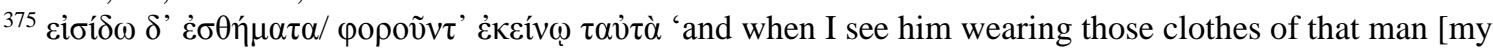
father]' (Soph., El., 268-9)

${ }^{376}$ Often is implied by ' $\dot{\varsigma} \varsigma \lambda \varepsilon^{\prime} \gamma o v \sigma ı v$ ' 'as they (are accustomed to) say' (Eur., El., 327)

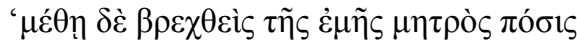

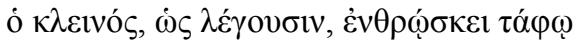

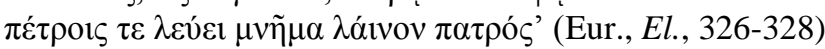

${ }^{377}$ Lanza, 1977, 234

${ }^{378}$ Seaford, 2003a, 97

${ }^{379}$ C.f. Lanza, 1977, 53

${ }^{380}$ Lanza, for example, thinks it is an important feature. C.f. Lanza, 1977, 55.
} 
think of everything in terms of money. ${ }^{381} \mathrm{I}$, however, believe, as explained above, that Creon and Oedipus' concern is based on excessive suspicion. In fact, I do not really believe there are any good examples of pure monetary greed in tragic rulers with the exception of Polymestor of Thrace in Hecuba. ${ }^{382}$ Aegisthus in Agamemnon is seen to be concerned about Agamemnon's money but only out of pragmatism so he can pay his guard:

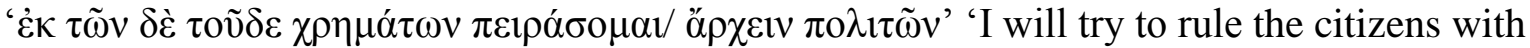
this man's money' (Aesch., Ag., 1638-9).

However, greed for power is universal. Sometimes it is rationalised as with Lycus, whose name, Wolf, as mentioned above, refers to his rapacious nature. ${ }^{383}$ As discussed in the last chapter, this is especially clear with Eteocles, whose greed for political power is shown in his agon speech. There, he expresses desire for $\tau$ ò $\pi \lambda \dot{\varepsilon}$ ov ('the greater') and personifies tyranny as the greatest goddess, a good thing ( $\tau$ ó $\chi \rho \eta \sigma \tau o ́ v)$, worth travelling to the sun, stars or underworld for, something which should be kept for himself. ${ }^{384}$

\section{Impiety (asebeia/dussebeia):}

Impiety (asebeia/dussebeia) is one of the most important moralising tyrant characteristics. ${ }^{385}$ The fact that the Greeks associated a wide range of taboo behaviours (e.g. murder of philoi, destruction of temples) with impiety makes this is into the most moralising tropes, used to characterise a tyrant beyond doubt as evil or at least deserving of his fate. ${ }^{386}$

There are numerous sub-tropes related to impiety in tragic tyrants. ${ }^{387}$ Mistreatment of suppliants (one of the tropes that no longer appears after tragedy) is one and the related trope of destruction of temples (though temple robbery does not occur) is another. Blasphemy, atheism or irreligiosity, dismissing prophecy, disrespecting the dead also occur. There are also some types of impiety that come with their own subtropes, namely destruction of reciprocity (for example, bonds of xenia and philia) and hybris. Adikia, as we have seen, often comes under impiety, however it has been discussed above.

A common form of impiety is mistreatment of suppliants-especially, as mentioned above, the children of the tyrant's enemy. This occurs in Heracles where Lycus threatens to burn

\footnotetext{
${ }^{381}$ Lanza, 1977, 55; Seaford, 2003a, 97

382 Eur., Hec., 25-7; 712

${ }^{383}$ Lanza, 1977, 50. Aegisthus is also described as a wolf by Cassandra at line 1259 in Agamemnon.

${ }^{384}$ Lanza, 1977, 53

${ }^{385}$ Lanza, 1977, 56

${ }^{386}$ As in the case of Oedipus, for example.

${ }^{387}$ Lanza, 1977, 56
} 
down the temple of Zeus where the Heraclids, their mother and grandfather are taking refuge. ${ }^{388}$ A somewhat similar situation is in the Heracleidae, where the Heraclids claim sanctuary from the semi-tyrant Eurystheus. Lycus, however, is a stronger example because the Heraclids in Heracles only have a temple to protect them, not a foreign king.

Another temple related trope occasionally seen is the destruction of temples. This only occurs once with a tyrant character when Lycus has his slaves: ${ }^{389}$

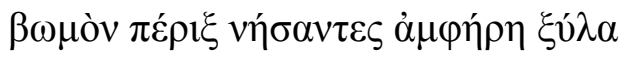

$\dot{\varepsilon} \mu \pi \dot{\mu} \mu \pi \rho \alpha \tau^{\prime} \alpha v ่ \tau \tilde{\omega} v \kappa \alpha \grave{~} \pi \nu \rho \circ \tilde{\tau} \tau \varepsilon \sigma \omega ́ \mu \alpha \tau \alpha$

$\pi \alpha ́ v \tau \omega v$

Heaping up regularly piled wood,

Set fire to them and burn them

all (Eur., $H F ., 243-5)$

Blasphemy is not actually as common in tragedy as professed irreligiosity but it does occur. ${ }^{390}$ Creon says that he would not bury Polyneices' body even if the eagles of Zeus desired it:

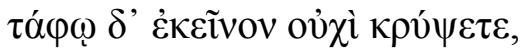

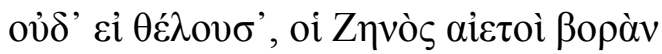

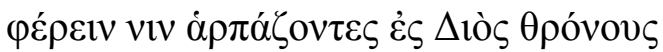

You will not cover him with a tomb,

Even if the eagles of Zeus, wishing to eat him

Snatched him up and bore him to the throne of Zeus (Soph., Ant., 1039-1041) (91 $^{391}$

The best example of this would be Pentheus, who does not believe that Dionysus is actually Dionysus. However, as this is also a very good example of hybris, we will discuss it there.

\footnotetext{
${ }^{388}$ Eur., $H F ., 240-6$

${ }^{389}$ Eur., $H F ., 240-6$. The non-tyrannical example when Hermione in Andromache, a character with some

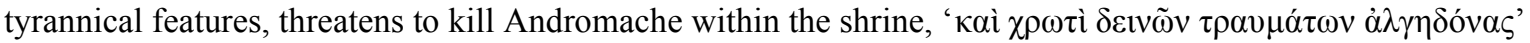
(Eur., Andr., 253-257; 259).

${ }^{390}$ Lanza, 1977, 56

${ }^{391}$ See also, Soph., Ant., 658-9, 777-8
} 
Professed irreligiosity or even atheism is more common than blasphemy and usually takes the form of claiming that the gods will not be affected by human affairs. ${ }^{392}$ This attitude is seen in an example immediately following Creon's blasphemous statement above:

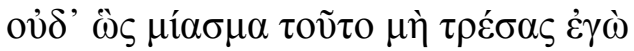

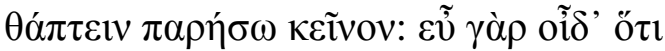

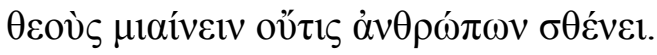

Nor will I permit him to be buried fearing

The pollution: for I know well that

Nothing within the power of mortals can pollute the gods. (Soph., Ant., 1042-4)

As Lanza points out, this is an idea that was current in fifth century thought. ${ }^{393}$ However, its role here is that, if the gods do not exist (or do not care), then impiety is impossible, and the tyrant's actions (in his opinion) cannot be judged within the conventional moral framework because this no longer matters. This is very similar to the argument used to justify 'might is right' by Eteocles and Callicles (especially the last two lines of Eteocles' speech). ${ }^{394}$

This example is also part of a quite common sub-trope of blasphemy or irreligiosity, dismissing prophets and prophecy. ${ }^{395}$ I discussed above the tendency of tragic tyrants to accuse Tiresias of mercenary motives, but this suspicion is often combined with some degree of irreligiosity, as we see in the example with Creon above. While it is not as seriously tyrannical or impious as traditionally considered, ${ }^{396}$ Oedipus is also prone to a little bit of this when he denies the veracity of prophecy in episode four:

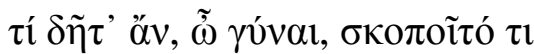

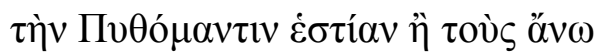

$\kappa \lambda \alpha ́ \zeta o v \tau \alpha \varsigma$ ő $\rho v \varepsilon 1 \varsigma, \tilde{\omega} v \dot{v} \varphi \eta \gamma \eta \tau \tilde{\omega} v \dot{\varepsilon} \gamma \grave{\omega}$

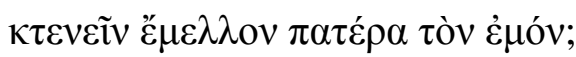

\footnotetext{
${ }^{392}$ Lanza, 1977, 56-8. I say "professed" because it is most often mentioned to support whatever impious action the tyrant is attempting at the time.

${ }^{393}$ Lanza, 1977, 56-7

${ }^{394}$ Lanza, 1977, 57

${ }^{395}$ Lanza, 1977, 234

${ }^{396}$ For example, Lanza and Winnington-Ingram, R. P. (1971). "The Second Stasimon of the Oedipus Tyrannus," The Journal of Hellenic Studies. 91: 119-135.
} 
... $\tau \grave{\alpha} \delta^{\prime}$ oũv $\pi \alpha \rho o ́ v \tau \alpha \sigma v \lambda \lambda \alpha \beta \grave{v} v \theta \varepsilon \sigma \pi i ́ \sigma \mu \alpha \tau \alpha$

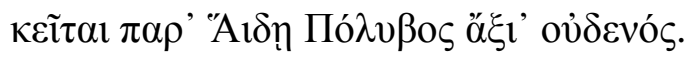

Why then, my lady, does anyone look at

The Pythian hearth or the birds screeching

Overhead, according to which guides I

Was going to kill my own father?

...but Polybus took away the present oracles with him

And they lie in Hades, worthless. (Soph., OT, 964-7, 971-2)

Disrespecting the dead is an element of impiety that is a breach of custom. The best examples of this is the refusal to bury the dead Argives by Creon - which is the subject of two plays, Sophocles' Antigone, ${ }^{397}$ and Euripides' Supplices. There is also the incident in Euripides' Electra in which Aegisthus dances drunkenly on Agamemnon's tomb. ${ }^{398}$

\section{Destroying the bonds of reciprocity:}

Destroying the bonds of reciprocity (i.e philia, xenia, orkia) is a very common part of impiety committed by tragic kings, because, as mentioned above, of its nature as a profoundly immoral act in Greek society. It is also, to a certain extent, the result of the nature of Greek myth which is full of kin-murder. It is a sub-trope of impiety, but also of adikia and hubris, as it is showing disrespect to the people and things that should be most honoured in Greek society. Mistreatment of one's parents and philoi in general or of one's guests, along with mistreatment of the gods, are the three 'cardinal sins' of classical Greece, as described by the Furies in the Eumenides:

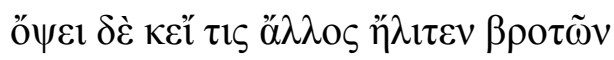

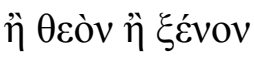

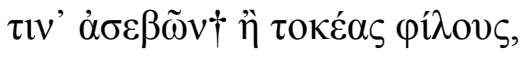

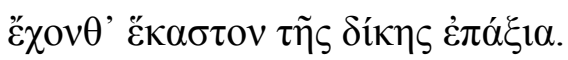

And you will see if some mortal sins

\footnotetext{
${ }^{397}$ Soph., Ant., 203-6

${ }^{398}$ Eur., El., 226-8
} 
Against the gods or a guest

Or his dear parents,

Each one will be worthy of punishment. (Aesch., Eu., 269-272)

The Furies themselves are an example of the level of pollution that comes upon someone who breaks these rules, bringing madness or even death to those who kill their parents, like Orestes in the Eumenides.

Within this, disrespecting and destroying the bonds of philia is a very common sub-trope. ${ }^{399}$ Murder of philoi is common enough in tragedy and those who murder their philoi are not always portrayed as tyrants - for example, Orestes, who killed his mother Clytaemnestra, and Agamemnon, who killed his daughter Iphigenia. However, murder of philoi is still considered bad enough to incur divine vengeance, and as such it is a common tyrant trait. The example par excellence of murder of philoi in tragedy would be Atreus' murder of his nephews, followed by the mythical trope of feeding them to their fatHdt. Creon in Antigone becomes another example when he has his niece Antigone executed. ${ }^{400}$ Eteocles, in Phoenissae, swears to kill his brother Polyneices and kills and is killed by him after fighting a war with him. In $O T$, Oedipus nearly ends up executing his brother-in-law, Creon, ${ }^{401}$ and then his killing of his father, like his incest, makes him still an example of this despite his lack of murderous intention. Zeus' treatment of Prometheus who cannot be killed because he is immortal would also come under this trope. A slightly less serious sub-trope of this, which still, as Catenacci has pointed out, ${ }^{402}$ is an indication of tyranny, is quarrelling with philoi. Creon's agon with Haemon is one of the best examples. ${ }^{403}$ The agon scene with Creon and Oedipus discussed above is also an example. ${ }^{404}$

Murder of xenoi, on the other hand, is not an act that a 'good' character can come back from. However, it is a trope lacking in the most prominent examples and only really occurs in Hecuba, when Polymestor murders his ward Polydorus, the son of his xenoi, the royal family

\footnotetext{
${ }^{399}$ Lanza, 1977, 48

${ }^{400}$ C.f. especially Soph., Ant., 486-9

401 Soph., OT, 623

${ }^{402}$ Catenacci, C. (2012). Il tiranno e l'eroe: storia e mito nella Grecia antica. Rome: Carocci: pp. 96-101:

Catenacci notes the destructions of father-son relationships. The best example is Periander's quarrel with his son Lycophron. Other than in Antigone, there are two other example of father-son agones (where one member is a king) in tragedy - Theseus/Hippolytus in Hippolytus and Admetus/Pheres in Alcestis, neither of which does any favours to its protagonist's characterisation, though neither Theseus and Admetus are actually characterised as tyrants.

${ }^{403}$ Soph., Ant., 640-675

${ }^{404}$ Soph., OT, 513-660
} 
of Troy. ${ }^{405}$ The seriousness of this breach of the bonds of xenoi is emphasised by Hecuba herself in the play:

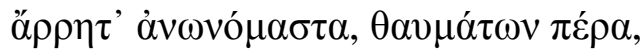

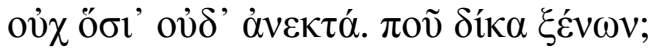

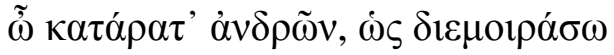

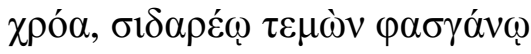

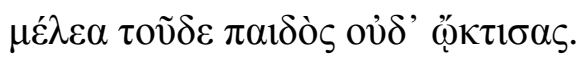

Nameless, unspeakable thing, beyond wonder,

Everything which is unbearable, where is $s$ the justice between guest friends?

Accursed among men, how you rent

His flesh, maiming the limbs of my boy with

An iron sword and showed no compassion! (Eur., Hec., 713-720)

\section{Hybris:}

Hybris is a trope related to impiety. Like impiety, it is very common. Here, with Fisher, we will define hybris as dishonouring another for your own pleasure, usually violently. ${ }^{407}$ Contrary to the prevailing opinion, Fisher points out that hybris usually consists of actions instead of thoughts, which makes the traditional definition of 'insolence' incorrect. ${ }^{408} \mathrm{He}$ also explains that hybris can and often be committed against men and not the gods. Tyranny is connected to hybris as many tyrants are portrayed as having come to power through hybris or being especially prone to commit hybris because great wealth and power, when taken to excess (koros) and combined with weakness of character makes them think themselves more important (and deserving of honour) than normal men. ${ }^{409}$

\footnotetext{
${ }^{405}$ Eur., Hec., 25-7; 710-712

${ }^{407}$ Fisher, N. R. (1992). Hybris: a study in the values of honour and shame in Ancient Greece, Warminster: Aris \& Phillips: p. 8

${ }^{408}$ Fisher, 1992, 8

${ }^{409}$ Fisher, 1992, 181
} 
Creon commits hybris in Antigone. Firstly, stasimon one, ${ }^{410}$ the famous catalogue of human achievements, ends with the statement, ${ }^{411}$ which contrasts ideal human social behaviour,

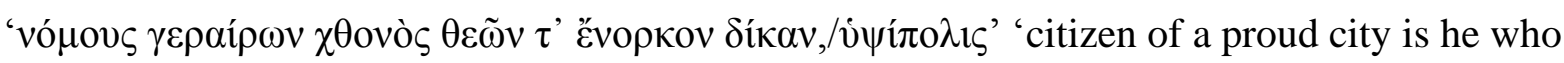
respects the laws of his land and the oathbound justice of the gods' [Soph. Ant., 369-70]) with

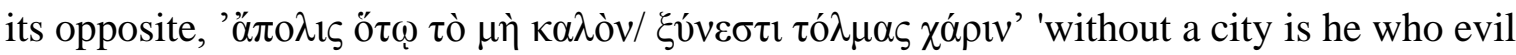
accompanies due to daring' (Soph. Ant., 370-1). This superficially refers to Antigone's burial of Polyneices, but ironically it refers to Creon, whose refusal to bury Polyneices is going

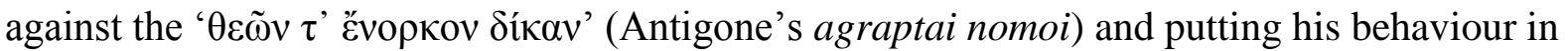
the second category-which represents hybris. The theme of hybris runs throughout the stasimon, with the ambiguous use of ' $\delta \varepsilon v$ ó' ('wonderful' or 'terrible') and the catalogue of actions traditionally associated with the initial acts of hybris that brought man out of the

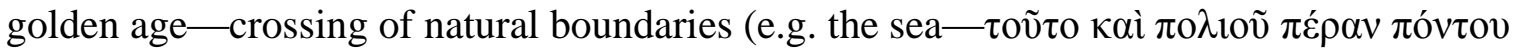

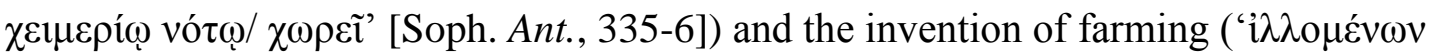

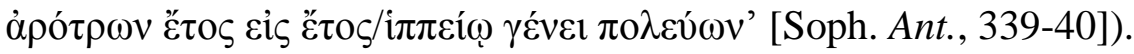

Oedipus is often considered an example of hybris because of the line 873 in the second stasimon. Before explaining why this is not the case, it is instructive to look at Stasimon Two, which is the only place in the play where hybris is explicitly mentioned. In Stasimon Two, the Chorus pray that they will remain pious (Strophe $\alpha$ ) unlike the man whose hybris leads him into tyranny (antistrophe $\alpha$ ). They ask that he be punished by gods (Strophe $\beta$ ) for his hybris and threaten that if he is not, they will cease to believe in the gods. Here, I am taking line 873 how it appears in the manuscript tradition as 'hybris begets the tyrant' not Blaydes' emendation 'kingship begets hybris'. ${ }^{412}$ The emendation allows the less controversial translation of tyrannis as 'kingship' and also the traditional idea of great power and wealth leading to hybris. However, tyrannis is amply attested in Greek tragedy, and Oedipus Tyrannus in particular, in its contemporary meaning of a bad king. Regarding the meaning, hybris as a cause of tyranny is perfectly well attested both because it leads to stasis and because the prospective tyrant must commit acts of hybris in order to become a tyrant. ${ }^{413}$ Fisher points out that the manuscript rendering can still have the same sense as the emendation, that hybris leads a good king into tyranny. ${ }^{414}$ In my opinion, this is unlikely as I

\footnotetext{
${ }^{410}$ Soph., Ant., 332-375

411 Soph., Ant., 369-371

412 The emendation is supported by Winnington-Ingram and Dawe, R.D. (1982). Sophocles: Oedipus Rex. Cambridge: Cambridge University Press.

413 Fisher, 1992, 182

414 Fisher, 1992, 184
} 
do not believe that Stasimon Two refers to Oedipus. As Fisher points out, ${ }^{415}$ Oedipus does not actually commit hybris during the play. His behaviour towards Tiresias and Creon is bad, but it is hasty judgement and thumos instead of hybris. ${ }^{416}$ Moreover, his easy capitulation to Jocasta is not characteristic of hybris. Again, his and Jocasta's rejection of oracles in Episode Three is not hybris as this is only words and not a direct insult to a god. Furthermore, it is the product of Jocasta and Oedipus' worried state of mind at the time (as opposed to the deliberate insults of Capaneus or Pentheus). ${ }^{417}$

Fisher points out that the Chorus could be worrying because of Oedipus' behaviour that he might start to behave more hubristically and descend into tyranny and the ode could be seen as an expression of this. ${ }^{418}$ However, it seems to me that the more common recent theory of the ode referring to the supposed murderers of Laius might be the correct one. ${ }^{419}$ However, the ode ironically refers to Oedipus, as Oedipus has committed the hybris of killing his father and marrying his mother, which according to Fisher, are such horrible crimes that they still somewhat count as hybris despite being accidental. ${ }^{420}$ Thus, these acts are the hybris that 'hybris begets the tyrant' ironically refers to. As Fisher points out, Oedipus' killing of Laius and his party is not hybris as it is done in self-defence or in direct retaliation nor would it be counted as hybris because Laius is a king: the idea of sacredness of kings is anachronistic. ${ }^{421}$

Agamemnon is a weaker example - his main tyrannical characteristic is his hybris (which is still lesser than that of his enemy Aegisthus and his wife). Agamemnon is part of a cycle of the generational hybris in the house of Atreus - which began with Atreus' murder of two of Thyestes' sons and continued when Agamemnon sacrificed his daughter Iphigenia. ${ }^{422}$ Agamemnon's own murder is the next step in this cycle which ends with Orestes' murder of Aegisthus and Clytaemnestra. ${ }^{423}$ The idea of generational hybris is that it is the god's

\footnotetext{
${ }^{415}$ Fisher, 1992, 181-2

416 Fisher, 1992, 182

417 Fisher, 1992, 182

418 Fisher, 1992, 183. C.f. Also Sheppard, J. T. (1922). The Oedipus Tyrannus of Sophocles. Cambridge: Cambridge University Press: p.10.

${ }^{419}$ See Sidwell, K. (1992). "The argument of the second stasimon of Oedipus Tyrannus," The Journal of Hellenic Studies. 112; 106-122; Gellie, G. H. (1964). "The second stasimon of the Oedipus tyrannus," The American Journal of Philology, 85(2): 113-123; Brandenburg, P. J. (2005). "The second stasimon in Sophocles' Oedipus tyrannus", L'Antiquité Classique, 29-40.

${ }^{420}$ Fisher, 1992, 183

${ }^{421}$ Fisher, 1992, 183: Oedipus' accidental marriage to his murder victim's widow is likewise not $h y b r i s$ in and of itself.

422 Fisher, 1992, 165-6

${ }^{423}$ Fisher, 1992, 166. At least in Aeschylus' Agamemnon. In mythology, it can be traced back to Pelops' murder of his charioteer.
} 
punishment of the previous generation's hybris; the gods actually push a man to commit hybris. ${ }^{424}$ This is the case of the sacrifice of Iphigenia, which in Agamemnon is presented as hybris. In this version, Iphigenia is an unwilling victim and the insufficient reasons for her sacrifice - retrieving Helen, pleasing the army (as opposed to saving a city or other reasons why human sacrifice is usually demanded) ${ }^{425}$ _makes this an example of hybris (as Agamemnon is dishonouring his daughter and his oikos). ${ }^{426}$ Agamemnon and the Greeks' behaviour at Troy was also hubristic. ${ }^{427}$ Agamemnon's hybris is emphasised when the Chorus sing of wealth breeding bloodshed and righteousness living in the homes of the poor. ${ }^{428}$ This refers to the Trojans on the surface level, but as Fisher has pointed out, it also refers to the house of Atreus whose wealth and continued prosperity came from their hubristic deeds (and whose hybris likewise came from their wealth and power). ${ }^{429}$

\subsection{Good Kings:}

The good king was a type that existed from Homer but became more fashionable in the late fifth and fourth centuries. We have discussed in chapter one how the ideal of kingship, or basileia, was based on arete. This idea carried on into the fifth and fourth centuries from the Archaic Period, but by the middle of the fifth, the arete that the king was expected to aspire to had taken on a decidedly moral quality.

This later 'good king' type is described fully in fourth century sources. The earliest examples specifically referring to kings are in Isocrates, ${ }^{430}$ and Xenophon's Agesilaus, ${ }^{431}$ but the idea is present also in Plato's Republic with the 'philosopher kings', ${ }^{432}$ and in Xenophon's Hiero ${ }^{433}$ and Aristotle's Politics where how to conserve a tyranny without cruelty is described. ${ }^{434}$ While the good tyrants in the Politics are still meant to be tyrants, Aristotle points out that to

\footnotetext{
${ }^{424}$ Fisher, 1992, 166

${ }^{425}$ Fisher, 166-7: The sacrifices of Macaria and Menoechus, for example, are clearly to save the city. The sacrifice of Polyxena in Hecuba is presented as having similarly ambiguous value.

${ }^{426}$ Fisher, 1992, 167

${ }^{427}$ Fisher, 1992, 167

428 Aesch., Ag., 772-783

${ }^{429}$ Fisher, 1992, 166-8. Fisher considers Agamemnon's stepping on cloths to be a very weak example of hurbis, if an example at all.

${ }^{430}$ Isoc., Ad Nic., passim and Isoc., Evag., passim

431 Xen., Ages., passim

432 Plato, Resp., $6.485 \mathrm{~d}-486 \mathrm{~d}$

${ }^{433}$ Xen., Hiero, 9-11

${ }^{434}$ Arist., Pol., 5.9.1314a-1315b
} 
govern in this way, a tyrant must behave like a king, ${ }^{435}$ and so what is described is basically the type of the good king.

The good king is primarily characterised by his arete and virtues. ${ }^{436}$ As with the tyrant, some of these virtues are actually related to the king's ruling, but others are included to characterise the king as the ideal Greek man. The good king is the steward of the state, whose aim is to serve and look after his people as opposed to himself and whose rule is characterised by lack of ambition. ${ }^{437}$ The good king is committed to dike: he does not break the country's laws but creates just laws and judges fairly. ${ }^{438} \mathrm{He}$ also does not punish his subjects severely but gives honour amply where it is due. ${ }^{439}$ The good king is generous and not greedy but spends public money wisely on the people — by building public buildings. ${ }^{440}$ A good king also encourages the people to virtue, by example, ${ }^{441}$ but also by rewarding and giving prizes for things like military outfit, excellence in farming or business. ${ }^{442}$ The good king is brave and has the manly virtue and endurance to, along with his other qualities, make him a good general. ${ }^{443}$ However, he always treats his enemies with mercy and respect. ${ }^{444}$

As well as traits that are directly related to ruling, the good king is characterised by moral virtues that are the opposite of the tragic tyrant-he always keeps his oaths and repays his debts, ${ }^{445}$ he is an exemplary philos and xenos and very pious - the good king respects the gods and their suppliants. ${ }^{446} \mathrm{He}$ is also a good example of sophrosyne - he does not rape or beat his subjects or commit any other act of hybris. ${ }^{447}$ This also extends to a lack of interest in luxury. ${ }^{448}$ The king is loved and respected not feared. ${ }^{449} \mathrm{He}$ is also an example of wisdom (sophia) and intelligence which he builds upon by taking ample advice from his advisors. ${ }^{450}$ Furthermore, he is able to bear both good and bad fortune. ${ }^{451}$ Moreover, the good king is

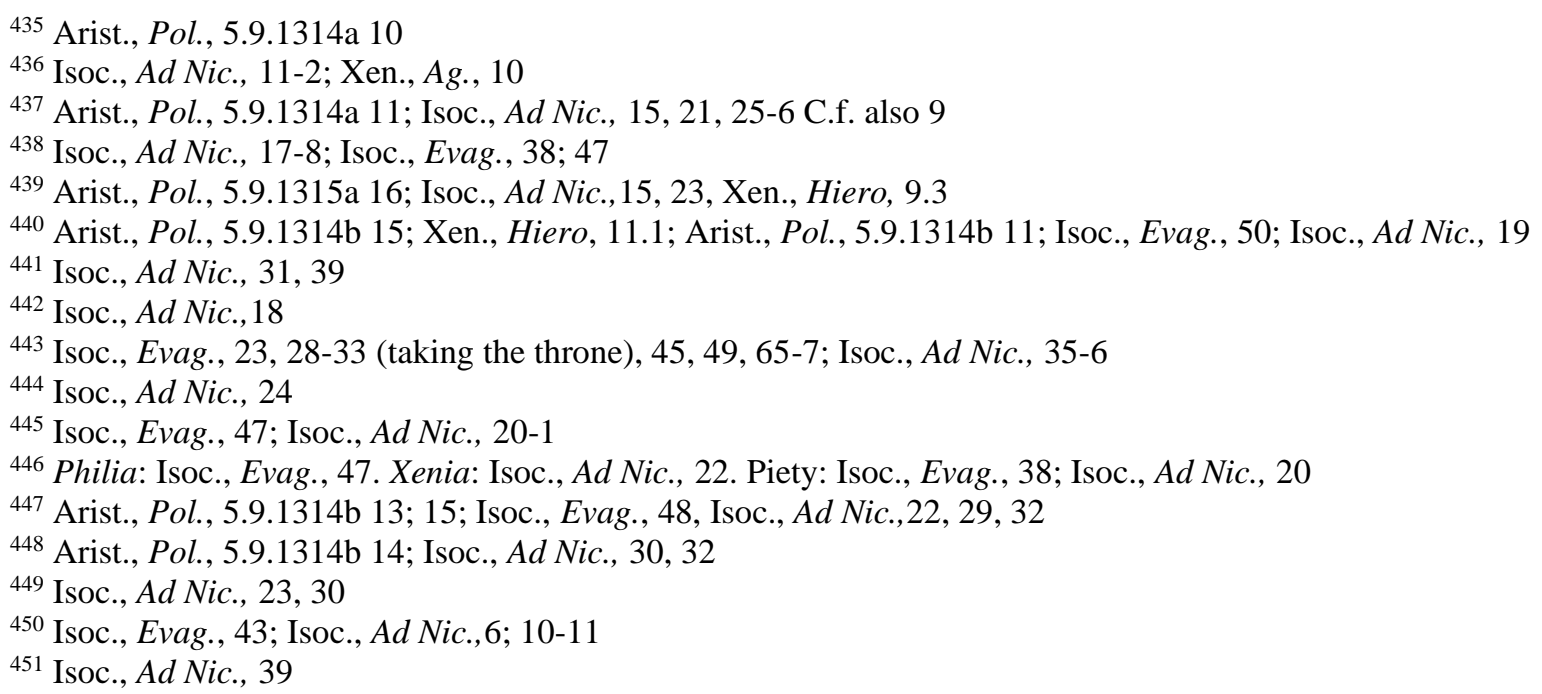


patriotic, humble, accessible, ${ }^{452}$ approachable, allows his people their freedoms, ${ }^{453}$ and able to cultivate a popular air but at the same time appear dignified. ${ }^{454} \mathrm{He}$ also does not listen to slanders. ${ }^{455}$

\section{The good king in tragedy:}

Good kings come in two formats in tragedy - firstly the pure good king form of the archaic and fourth century models and the good king with democratic features (i.e. the democratic king) who we will discuss below. ${ }^{456}$ It is likely that the decision to characterise kings one way or another was based less on whether the work was written later with the resurgence of the popularity of sole-rule in Athenian thought than on the nature of the play - a play concerned with politics like both Supplices plays could be expected to make use of a democratic king whereas one like Oedipus Tyrannus, which was more concerned with cult would be expected to use a more traditional kind of good king. ${ }^{457}$

Oedipus, surprisingly, is the major example of the traditional kind of good king. ${ }^{458}$ At the start of Oedipus Tyrannus, he is the archetypal example of the good king, yet also a good example of a tyrant. ${ }^{459}$ Oedipus starts the play off as the good king: in the prologue, he displays concern for his subjects' welfare when he arrives to talk to them in person 'not

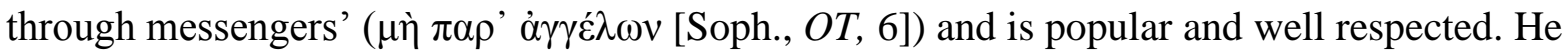
is hard-working, resourceful and takes immediate action when he makes up a plan, sends Creon to Delphi and sends for Tiresias. ${ }^{460} \mathrm{He}$ also, at least for rhetorical effect, addresses his subjects as his 'children' invoking the paternal air which was associated with good kings. However, Oedipus does not show a wide range of 'good king' traits. Even at the beginning of the play, he is a weak example as he displays ambition and lacks humility. Lanza claims that his status as a good king is destroyed by his behaviour to Tiresias and Creon. ${ }^{461}$ However, Oedipus' behaviour towards Tiresias and Creon is not particularly serious and his mercy to Creon somewhat neutralises his intention to kill him. The possible reference to Oedipus in

\footnotetext{
${ }^{452}$ Unlike, for example, the Persian kings.

${ }^{453}$ Isoc., Ad Nic., 27-8

454 Isoc., Ad Nic., 34

455 Isoc., Evag., 46; Isoc., Ad Nic., 28

456 Mitchell, 20

${ }^{457}$ I'd like to thank Simon Perris for pointing this out to me.

${ }^{458}$ Knox, 1966, 59-60

${ }^{459}$ Lanza, 1977, 141. See also Perris, 2017, 331

${ }^{460}$ Lanza, 1977, 141

${ }^{461}$ Lanza, 1977, 141-6: Lanza posits that Oedipus begins as the good king, becomes a tyrant and then his own destroyer. He posits that Oedipus is characterised as a good king at the start to contrast his later character changes.
} 
$\pi \alpha \dot{\lambda} \alpha 1 \sigma \mu \alpha$ 'contest' (Soph., OT, 881) and his continued searching for the murder of Laius (and his reaction to the knowledge that he might have killed Laius in episode three) shows that Oedipus has not lost the characterisation of the good king. ${ }^{462}$

\section{Democratic Kings:}

Democratic kings are the second and more common subtype of the 'good king' in tragedy who are characterised by heading a democratic regime to mark them out as good in a play with political conflicts (i.e. especially the patriotic dramas of Euripides). ${ }^{463}$ The three instances of democratic kings in tragedy are Pelasgus (Aeschylus' Supplices), Theseus (Euripides' Supplices) and Demophoon (Heracleidae). This type of ruler never existed although some Athenians believed that Theseus, the prime example of this type, founded the Athenian democracy. ${ }^{464}$ Regardless, it is clear that democracy is being used in these examples as a device for showing a ruler as good in the same way as the tyrant tropes are used to characterise a ruler as bad. ${ }^{465}$ Mitchell characterizes the democratic king as a prostas tou demou 'champion of the people' figure like Pericles, the kind of guiding statesman whose benevolent sole rule the democracy needs in order to function. ${ }^{466}$ Somewhat less radically, West defines the democratic king as a king who gets his people's permission to act through an assembly and voting. ${ }^{467}$ As West points out, the procedure which is seen in plays with democratic kings - a measure is referred by the king to the assembly who vote on it is strikingly similar to the early proto-democratic procedure (for example that seen in the Spartan Rhetra) and to the assemblies in Homer. ${ }^{468}$

Pelasgus of Argos in Aeschylus' Supplices is the earliest example of this type of good king. He has features of the good king in general - his piety and respect for tradition makes him help the suppliants and it is clear from his success in the assembly that he is popular with his people. As a democratic king, Pelasgus turns the final decision on whether or not to give sanctuary to the Argives over to the people of Argos. ${ }^{469}$ He then then follows protodemocratic procedure and puts a motion on whether the Danaids should be given sanctuary to

\footnotetext{
462 Gellie, 1964, 121

${ }^{463}$ Perris, 2018

${ }^{464}$ Easterling, 1985, 3

${ }^{465}$ West, 2013, 200

${ }^{466}$ Mitchell, L. (2008). "Thucydides and the Monarch in Democracy". Polis: The Journal of the Society for Greek Political Thought, 25(1), 1-30: pp. 25-6

${ }^{467}$ West, 2013, 200

468 West, 2013, 199

${ }^{469}$ Aesch., Supp., 365-9
} 
the assembly. ${ }^{470}$ He persuades the people by giving a speech. ${ }^{471}$ They then vote (by show of hands) that the Danaids should be allowed to stay. ${ }^{472}$

Theseus in Euripides' Supplices is perhaps the best example of this type of tragic king. This is probably because of the agon speech which, as discussed above, portrays him as having highly developed anachronistic ideas about democracy. Theseus, like Pelasgus, ${ }^{473}$ refers the decision on his suppliants to the assembly and speaks on behalf of them. ${ }^{474}$ However, as Mitchell points out, there is a negative aspect to Theseus' role as a sole ruler: he is willing to help the Suppliants only when his mother brings up his own honour-subverting the ideal of the good king as a defender of custom and dike for its own ends - and he speak for the people and assumes they are going to agree to him without consulting them. Like the people's champion (prostas tou demou), he is a potential tyrant from the use of overt power. ${ }^{475}$ Moreover, Theseus decries the failings of both the rich and poor in a speech to Adrastus about his shortcomings as a ruler, which makes Theseus seem more in the party of 'to meson' than radical democracy. ${ }^{476}$ Perhaps, however, Aethra's appeal to his honour at least harks back to earlier Homeric and Archaic models of good kings - of which Euripides' Theseus does show some traits, displaying his arete through his eventual decision to fight for the right to bury the dead and his bravery in war, as well as his willingness to explore other options instead of fighting, showing that he cares more for his people than his own honour. ${ }^{477}$

Demophoon in Heracleidae is another example, who Euripides manages to characterise as a democratic king without giving him a pro-democracy agon speech. In this play, Demophoon and his brother Acamas have actually received their positions by lot, like some positions in democratic Athens. ${ }^{478}$ We are not told if Demophoon calls an assembly on the issue of going to war as his father does, but the assembly does debate the issue of sacrificing a virgin for the sake of the suppliants. ${ }^{479}$ Demophoon is also portrayed as beholden to the assembly; ${ }^{480}$ he must please public opinion or risk ridicule ( $\tau \tilde{\omega} v \delta \dot{\varepsilon} \mu \omega \rho i ́ \alpha v \dot{\varepsilon} \mu$ ov/ $\kappa \alpha \tau \eta \gamma o \rho o v ́ v \tau \omega v$, 'others

\footnotetext{
${ }^{470}$ Aesch., Supp., 365-9

471 Aesch., Supp., 623

472 Aesch., Supp., 600-609; West, 2013, 197-9

${ }^{473}$ Mitchell, 2008, 14 n. 83

${ }^{474}$ Eur., Supp., 349

475 Mitchell, 2008, 14-6.

${ }^{476}$ Eur., Supp, 238-245. Mitchell, 2008, 14-5

${ }^{477}$ Eur., Supp., passim

${ }^{478}$ Eur., Hdt., 34-6

${ }^{479}$ Eur., Hdt., 415-8

${ }^{480}$ Like Pelasgus in Aeschylus' Supplices
} 


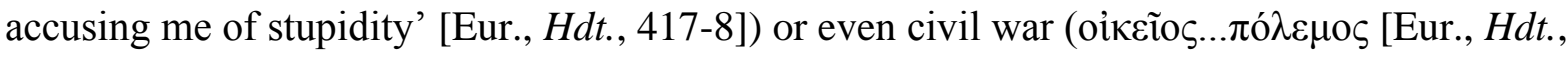
419]) and he goes as far as to state:

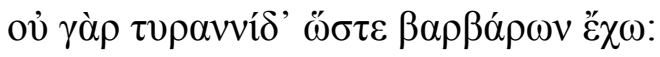

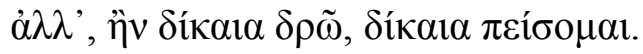

For I do not have a tyranny like that of the barbarians:

Rather if I do just things, I will be treated justly. (Eur., Hdt., 423-4)

Demophoon also shows other, broader, good king traits. He displays no hesitancy in giving the Heraclids sanctuary and even after receiving the oracle about the sacrifice of a virgin, he is keen on finding a way around the situation. ${ }^{481} \mathrm{He}$ constantly shows a commitment to the bonds of philia (he is a distant relative of the Heraclids) and xenia. His reluctance to let an Athenian girl die is based on sound democratic principles; he will not force his citizens to sacrifice their daughters against their wills (as a tyrant would), as he does not have the right of life and death over his citizens. ${ }^{482}$ All in all, his ability to balance the needs of piety, xenia (his father and Heracles were guest-friends) and his duty to his polis are examples of a good king's display of arete. ${ }^{483}$

\subsection{Other rulers:}

The other examples of rulers in tragedy are those who Perris describes as heroic/mythical sole rulers and Eastern kings. Perris' category of heroic/mythical sole rulers contains kings who do not have anachronisms in their characterisation major enough to come under the categories of tragic tyrant or good king. This rule is basileia based on transferal of power within the oikos, though not necessarily from father to son, and willing obedience of the subjects. Examples include Theseus in Oedipus at Coloneus and Hippolytus, Agamemnon in Agamemnon and Admetus in Alcestis.

Perris divides Eastern kings into two groups — foreign god kings (i.e. Xerxes and Darius in the Persae) and others. Xerxes and Darius are unique in that they are based on recent historical figures from a real regime (that presumably the audience knew a little about).

\footnotetext{
${ }^{481}$ Eur., Hdt., 410-1; 420-1

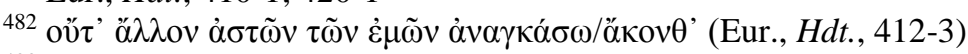

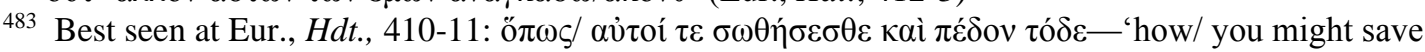
yourselves and this land'.
} 
Xerxes shares some characterisation with the tragic tyrants - as we discussed in chapter two, the Persians use whips on their own soldiers and Xerxes is prone to hybris. However, more so than with the Persian kings in Herodotus who display many of the traits later seen in tragic tyrants, ${ }^{484}$ he is not portrayed as a tyrant but as a foreign king.

Of the other Eastern kings, the portrayal varies between bogeymen like the Egyptian king in Aeschylus' Supplices and more nuanced portrayals like Thoas in Iphigenia in Tauris and Theoklymenos in Helen. The latter are seen in relatively similar situations-both are tricked into allowing Greek prisoners to escape while they are pretending to carry out religious rites and are angered over this. Thoas threatens to have Orestes and Pylades thrown off a cliff or impaled, ${ }^{485}$ whereas Theoklymenos plans to kill his sister for not revealing Menelaus' existence to him. ${ }^{486}$ Both act rather tyrannical here, but their behaviour before and after is relatively good, especially with regards to piety as both let their pursuit go when told to by the gods. ${ }^{487}$

\section{Conclusion:}

In order to comment on contemporary politics, the Greek tragedians took the Homeric kings who were the subjects of their tragedies and moulded them into different forms. Some good kings stay relatively Homeric in nature, others take on more anachronistic traits, including democratic features, according to context. However, certain rulers were made into tyrants, in line with negative attitudes to sole rule in the fifth century and the antithesis between the tyrant and the good king which was present at the time. Many were weakly characterised as tyrants, with tyrannical features only being used to mark their characters as evil, but others were formed fully into what we can call the tragic tyrant. This figure was made up of rulepreserving and purely moral traits. The former-extrajudicial murder, depriving one's subjects of the rights owed to a free man and a citizen and unjust rule are all common in the small group of tyrants who are fully characterised. The latter are just as present, especially impiety (a universal trait) of all tyrants, and anger.

\footnotetext{
${ }^{484484}$ Cambyses being the best example. C.f. Hdt. 3.30.3; 3.32 (murder of philoi), Hdt. 3.31 (incest), Hdt. 3.36 (mistreatment of advisors) etc.

${ }^{485}$ Eur., IT, 1429-1430.

${ }^{486}$ Eur., Hel., 1624-1641

${ }^{487}$ Eur., IT, 1475-1485; Eur., Hel., 1680-1687
} 


\section{Conclusion:}

What conclusions can we make about tyranny as a regime type and the tragic tyrant? Having come this far, there are several key conclusions that I would like to stress. Firstly, the study of tragic tyranny can be illuminated by studying its origins in Archaic tyranny and how a real regime type became first an ideological concept and then a literary device.

Modern scholarship has shown that many of the behaviours the classical Greeks attributed to tyrants were not based in the historical reality of the Archaic tyrant - a type of monarch who was part of the aristocracy and governed with the same methods. However, significant elements, such as stasis, philotimia and, to lesser extent, populism, of the literary tyrants seem likely to be inspired by real circumstances of archaic tyranny, as intra-elite and class stasis as well as elite attitudes that placed importance on personal aretē and glory were among the causes of Archaic tyranny.

While tyranny was originally viewed as good thing which was greatly desired, this atttitude declined with the emergence of the concept of isokratia, first among the elite and then among the nascent democracies, and the tyrant came to be seen as a figure who took away the rights of the people for his own gain, the opposite of the ideal citizen who served the polis before himself. In Athens, this led to the development of tyranny as a potent ideological concept, used especially as a foil to democracy, but also to either vilify or find common ground with the oligarchs who rose in opposition to democracy from the older aristocratic ideals. The concept of tyranny eventually became irrelevant in the political sphere, but it lived on in literature.

Tyranny as evil and the contrast between tyranny and democracy were both anachronistic ideas that made their way into Greek tragedy. Their appearance was built on a network of political anachronisms, including the polis and money, that are more common than often believed in scholarship. By looking in detail at the very common anachronism of the contrast between democracy and tyranny, often expressed through contrasting democratic and tyrannical characters and agon scenes, we can see the increasing inclusion of anachronistic political discourse relating to tyranny in Greek tragedy. 
The most potent anachronism in Greek tragedy is the tragic tyrant. The tragic tyrant is a figure, not yet a stock type, who can be defined by tropes that are categorised as belonging to him in Herodotus and the fourth century philosophers. The tyrant can also be identified by his involvement in the polis and the inclusion of political discourse (without which he is simply a weak version of himself, a 'semi-tyrant') in his plays. The tropes we see in the tragic tyrant can be categorised according to whether they are based on power-preserving actions (for example, purges of the best men) or simply moralising (for example, impiety). That there is a wide range of these tropes in tragedy and that most tropes that we find in the fourth century prose sources are also seen in tragedy tells us that the tragic tyrant was a significant and welldeveloped figure. The tragic tyrant was also fundamentally complete in its earliest iterations (as we can see from Aegisthus in Agamemnon, our earliest extant example) which shows us that the tragic tyrant was likely based on contemporary portrayals of tyranny in the political sphere. The tragic tyrant is part of a larger phenomenon of anachronistic rulers in tragedy that includes Eastern kings and the good king and his subtype the democratic king. The good king is more significant because he also has his own set of features which can be seen in the fourth century writers.

In conclusion, the existence of tyrant tropes used in the portrayal of the tragic tyrant is significant and should not be overlooked. This topic is a is a rich one: it may run the risks of generalisation but is fertile in teaching us about literary trends and values in Fifth Century Athens as well as Greek tragedy's engagement with contemporary politics and political theory. Further study is merited, especially as there is a wealth of Greco-Roman literature with literary tyrants who could be compared, to great scholarly interest, with the tyrants of fifth century tragedy. It would not be unfounded to suggest that the tragic tyrant's existence was and is significant to the development of the literary tyrant in Western literature and that the descendants of Aegisthus and Creon will continue to be seen in media for years to come. 
Appendix A: A Categorisation of Tyrant Tropes:

\begin{tabular}{|c|c|c|}
\hline Umbrella trope & Trope & \\
\hline Illegitimate rise to power & • & $\begin{array}{l}\text { Coup (rare) } \\
\text { Aegisthus in Agamemnon (Aesch., } \\
\text { Ag., 1604-1611) } \\
\text { Demagoguery (absent) } \\
\text { Mentioned in Plato's Republic } \\
\text { (Plato, Resp., 565b-566b) } \\
\text { Stasis (rare) } \\
\text { Lycus in Heracles Furens (Eur., HF, } \\
\text { 132-5) } \\
\text { Trickery (rare) } \\
\text { Zeus in Prometheus Vinctus (Aesch., } \\
\text { PB, 215), among others } \\
\text { "Bodyguard trick" (absent) } \\
\text { Peisistratus in Herodotus (H. 1.59.3- } \\
\text { 6) }\end{array}$ \\
\hline Fear (phobos) & $\bullet$ & $\begin{array}{l}\text { Constant fear/paranoia (phobos) of } \\
\text { plots and being overthrown } \\
\text { Oedipus in Oedipus Tyrannus } \\
\text { (Soph., OT., 124-5); Creon in } \\
\text { Antigone (Soph., Ant., 534), among } \\
\text { others } \\
\text { Not trusting friends/advisors } \\
\text { Oedipus in Oedipus Tyrannus } \\
\text { (Soph., OT, 385-7); Zeus in } \\
\text { Prometheus Vinctus (Aesch., PB., } \\
\text { 220-225), among others } \\
\text { Suspicion of bribery }\end{array}$ \\
\hline
\end{tabular}




\begin{tabular}{|c|c|}
\hline & $\begin{array}{l}\text { Creon in Antigone-with the guards, } \\
\text { (Soph., Ant., 293-294) and Tiresias } \\
\text { (Soph., Ant., 1034-6); Oedipus in } \\
\text { Oedipus Tyrannus (Soph., OT, 388- } \\
\text { 9) } \\
\text { - Envy (phthonos) } \\
\text { Oedipus in Oedipus Tyrannus } \\
\text { (Soph., OT, 380-1); Eteocles in } \\
\text { Phoenissae (Eur., Phoen., 543-6), } \\
\text { among others } \\
\text { Tyrant as miserable (rare) } \\
\text { Oedipus in Oedipus Tyrannus, } \\
\text { Aegisthus in Euripides' Electra } \\
\text { (Eur., El., 617), among others } \\
\text { - } \text { Needs flattery/reassurance } \\
\text { Oedipus in Oedipus Tyrannus } \\
\text { (Soph., OT, 616-7; 631ff) and Creon } \\
\text { in Antigone (Soph., Ant., 635-8; 701- } \\
\text { 4), among others } \\
\text { Lycus in Heracles furens (Eur., HF, } \\
\text { 165-9), Eteocles in Phoenissae } \\
\text { (Eur., Phoen., 782-3), among others }\end{array}$ \\
\hline $\begin{array}{l}\text { Precautionary/Power-Consolidating } \\
\text { measures }\end{array}$ & $\begin{array}{l}\text { Bodyguard/mercenaries (rare) } \\
\text { Aegisthus in all plays (Aesch., Ag., } \\
\text { 1638-9), (Eur., El., 615-633; 798) } \\
\text { Promotion of foreigners and lower } \\
\text { classes/slaves as henchmen (absent) } \\
\text { Mentioned in Plato’s Republic } \\
\text { (Plato, Resp., 567d) } \\
\text { - Frees slaves (absent) }\end{array}$ \\
\hline
\end{tabular}




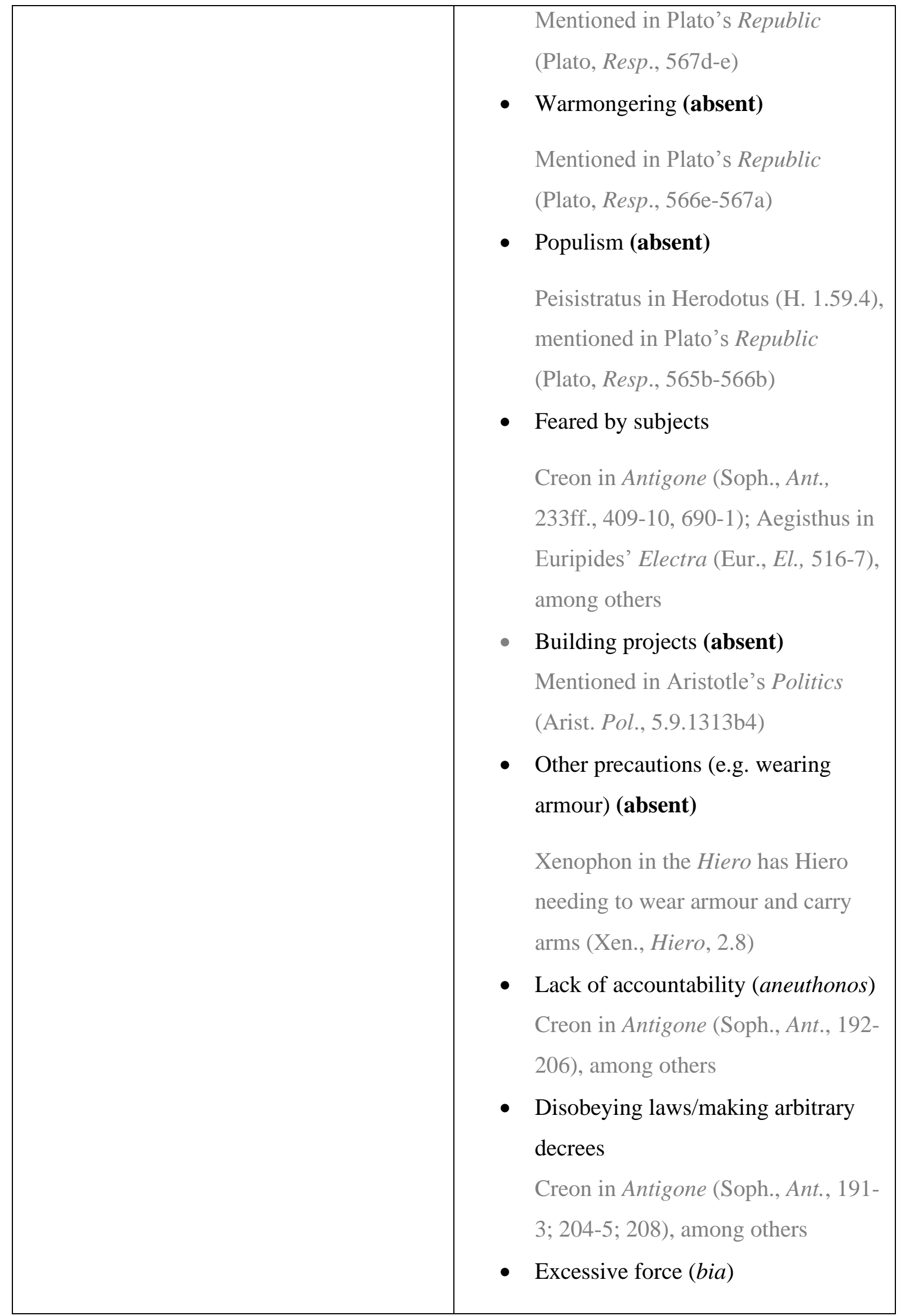




\begin{tabular}{|c|c|}
\hline & $\begin{array}{l}\text { Zeus' henchman Bia in Prometheus } \\
\text { Vinctus, among others }\end{array}$ \\
\hline Depriving citizens of their rights & 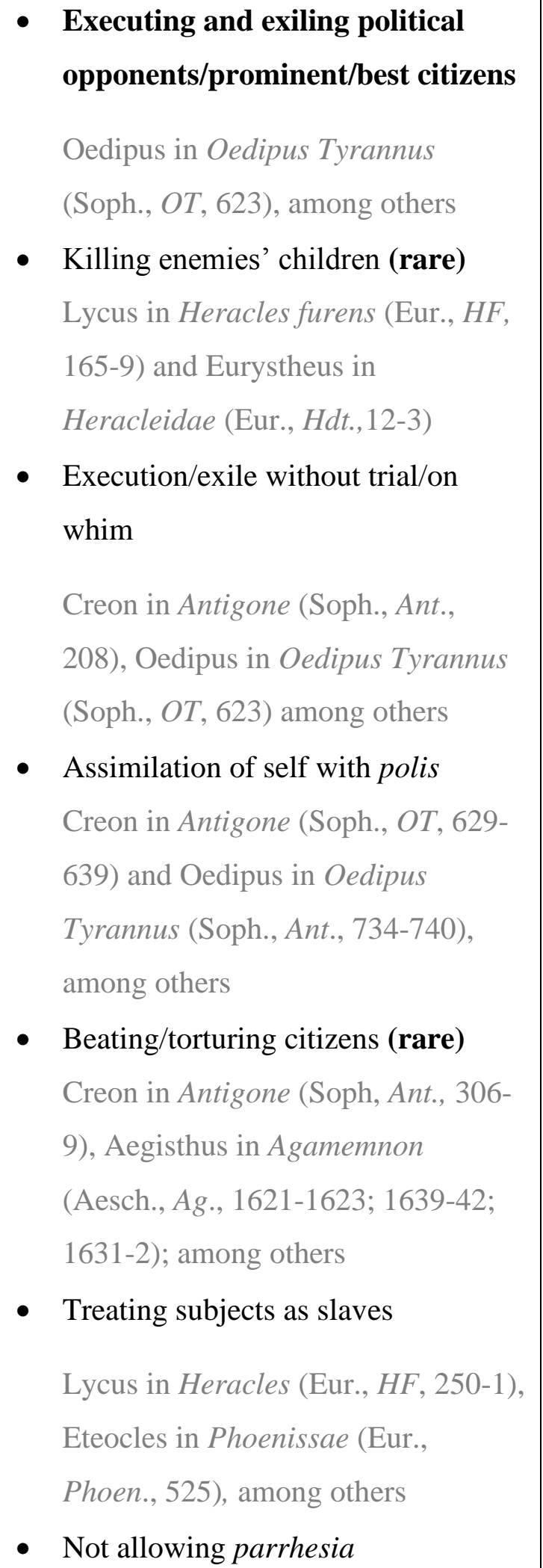 \\
\hline
\end{tabular}




\begin{tabular}{|c|c|}
\hline & $\begin{array}{l}\text { Creon in Antigone (Soph., Ant., } \\
\text { 233ff., 409-10, 690-1), Aegisthus in } \\
\text { Agamemnon, among others } \\
\text { - Not allowing public gatherings } \\
\text { (rare) } \\
\text { Creon in Antigone (Soph., Ant., 289- } \\
\text { 291) } \\
\text { - Informers (absent) } \\
\text { Mentioned in Herodotus (H. 3.80.4) } \\
\text { Using spies/secret police (rare, if } \\
\text { not absent) } \\
\text { Maybe Creon in Antigone (Soph., } \\
\text { Ant., 289-291) and Aegisthus in } \\
\text { Euripides' Electra (Eur., El., 516-7). } \\
\text { Mentioned in Aristotle's' Politics } \\
\text { (Arist., Pol., 5.9.1313b 3) } \\
\text { Confiscation of property (absent) } \\
\text { Cypselus in Herodotus (H. 5.92e2) }\end{array}$ \\
\hline Injustice (adikia) & $\begin{array}{l}\text { Creon in Antigone (Soph., Ant., 450- } \\
460 \text { ) and Euripides' Supplices (Eur., } \\
\text { Supp., 563), Eteocles in Phoenissae } \\
\text { (Eur., Phoen., 624-5), among others }\end{array}$ \\
\hline Lack of self-control (akrolasia) ${ }^{360}$ & $\begin{array}{l}\begin{array}{l}\text { Anger (especially at advisors) } \\
\text { (orge/cholos) }\end{array} \\
\text { Oedipus in Oedipus Tyrannus } \\
\text { (Soph., OT, 357-8, 365); Creon in } \\
\text { Antigone, among others } \\
\text { - Flashing eyes (rare) }\end{array}$ \\
\hline
\end{tabular}




\begin{tabular}{|c|c|}
\hline & $\begin{array}{l}\text { Creon in Antigone (Soph., Ant., 690) } \\
\text { and Eteocles in Phoenissae (Eur., } \\
\text { Phoen., 454) } \\
\text { - } \quad \text { Hastiness/jumping to conclusions } \\
\text { Oedipus in Oedipus Tyrannus } \\
\text { (Soph., OT, 523-4; 634-641), among } \\
\text { others } \\
\text { - Cruelty } \\
\text { Lycus in Heracles furens (Eur., HF, } \\
\text { 165-9), among others } \\
\text { - Madness (absent) } \\
\text { Cambyses in Herodotus (H. 3.29.1; } \\
\text { 3.30.1; 3.33) } \\
\text { - Lust (see below) } \\
\text { - } \quad \text { Luxureed (see below) } \\
\text { (see below) }\end{array}$ \\
\hline $\begin{array}{l}\text { Luxury (rare) Aegisthus in Euripides' and } \\
\text { Sophocles' Electra only }\end{array}$ & $\begin{array}{l}\text { - Drinking (rare) } \\
\text { Aegisthus in Euripides' Electra } \\
\text { (Eur., El., 326-328) } \\
\text { - Banqueting (absent) } \\
\text { Mentioned in Aristotles' Politics } \\
\text { (Arist., Pol., 5.9.1314b 14) } \\
\text { - Dressing tyrannically (rare) } \\
\text { Sophocles' Electra (Soph., El., 268- } \\
\text { 9) } \\
\text { General (rare) Aegisthus in } \\
\text { Sophocles' Electra (Eur., El., 1290- } \\
\text { 1) }\end{array}$ \\
\hline Lust/Sexual Crimes (rare) & $\begin{array}{l}\text { - } \text { Rape (rare) } \\
\text { Aegisthus in Euripides' Electra } \\
\text { (Eur., El., 1945-8) }\end{array}$ \\
\hline
\end{tabular}




\begin{tabular}{|c|c|}
\hline & $\begin{array}{l}\text { - Incest (rare) } \\
\text { Oedipus in Oedipus Tyrannus } \\
\text { (Soph., OT, passim); Cambyses in } \\
\text { Herodotus (H. 3.31) } \\
\text { - Adultery (rare) } \\
\text { Aegisthus in everything (e.g. Eur., } \\
\text { El., 920) } \\
\text { Effeminacy (rare) } \\
\text { Aegisthus in Euripides' Electra } \\
\text { (Eur., El., 930-933; 949-951) } \\
\text { Sexual perversion (e.g. taking the } \\
\text { passive role during sex, anal sex, } \\
\text { necrophilia) (absent) } \\
\text { Periander committing necrophilia } \\
\text { with his wife's body (H. 5.92g) and } \\
\text { Peisistratus having anal sex with } \\
\text { Megacles' daughter (H. 1.61.1-2) in } \\
\text { Herodotus. }\end{array}$ \\
\hline Gain (kerdos) & $\begin{array}{l}\text { - Greed for money (rare) } \\
\text { Aegisthus in Agamemnon (Aesch., } \\
\text { Ag., 1638-9) and Polydeuces in } \\
\text { Hecuba (Eur., Hec., 25-7; 712) } \\
\text { - Greed for power } \\
\text { Lycus in Heracles furens in his very } \\
\text { name lykos ('wolf'); Eteocles in } \\
\text { Phoenissae (Eur., Phoen., 505-7, } \\
\text { 524-5), among others } \\
\text { Excessive taxation (absent) } \\
\text { Mentioned in Plato's Republic } \\
\text { (Plato, Resp., 566e-567a) and }\end{array}$ \\
\hline
\end{tabular}




\begin{tabular}{|c|c|}
\hline & $\begin{array}{l}\text { Aristotle's Politics (Arist. Pol., } \\
\text { 5.9.1313b5) } \\
\text { - Confiscation of property (absent) } \\
\text { (see above) } \\
\text { - Killing people for their money } \\
\text { (rare) } \\
\text { Polydeuces in Hecuba (Eur., Hec., } \\
\text { 25-7; 710-721) }\end{array}$ \\
\hline Cowardice & 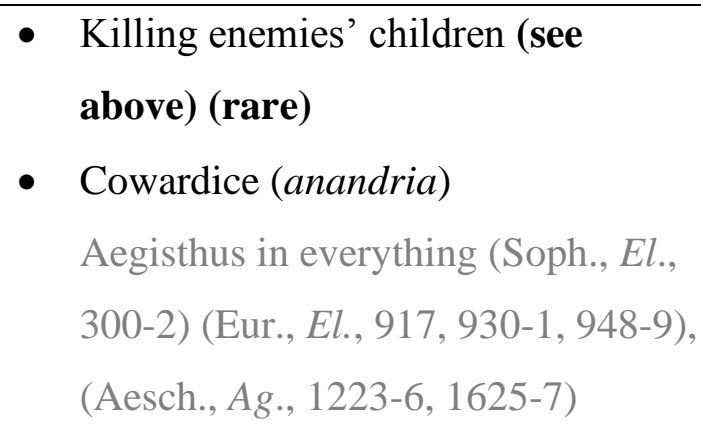 \\
\hline Impiety (asebeia/dussebeia) & 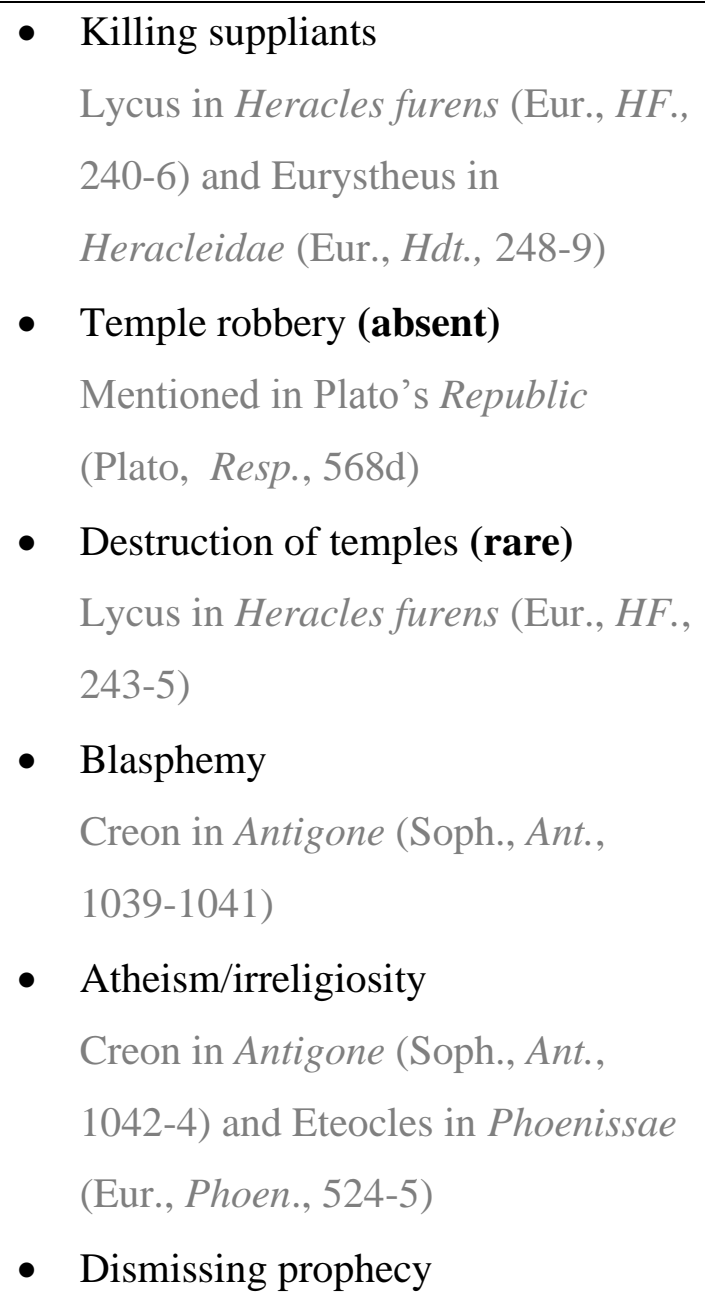 \\
\hline
\end{tabular}




\begin{tabular}{|c|c|}
\hline & $\begin{array}{l}\text { Creon in Antigone (Soph., Ant., } \\
\text { 1033-1047) } \\
\text { - Disrespecting the dead (rare) } \\
\text { Creon in Antigone (Soph., Ant., 203- } \\
\text { 6) and Euripides'Suppliants (Eur., } \\
\text { Supp., 563) } \\
\text { - Lack/destruction of reciprocity } \\
\text { (see below) }\end{array}$ \\
\hline Lack/destruction of reciprocity & $\begin{array}{l}\text { Killing philoi } \\
\text { Eteocles in Phoenissae (passim), } \\
\text { Creon in Antigone (Soph., Ant., 486- } \\
\text { 9), among others } \\
\text { - Killing xenoi (rare) } \\
\text { Polydeuces in Hecuba (Eur., Hec., } \\
\text { 25-7; 710-721) }\end{array}$ \\
\hline Hybris & $\begin{array}{l}\text { Creon in Antigone (Soph., Ant., 369-71), } \\
\text { among others }\end{array}$ \\
\hline
\end{tabular}




\section{Appendix B: The evolution of tyrant tropes in tragedy:}

The tragic tyrant does not appear in Aeschylus' earlier extant plays, ${ }^{488}$ which do not contain evil king figures. ${ }^{489}$ The sole-rule/democracy antithesis (the earlier version of the tyranny/democracy antithesis), however, appears even in his earliest play, the Persae, as we saw in chapter two.

The earliest evidence of the literary tyrant, before even Herodotus' Histories in 440 B.C.E., is Aegisthus in Aeschylus' Oresteia (produced in 458 B.C.E). Aegisthus is actually a surprisingly fully developed version of the tragic tyrant, showing us that the stereotyped tragic tyrant was likely present in political rhetoric before its first appearance in literature, although it is possible that the tragic tyrant appears in earlier lost plays. Most tyrant tropes are present in Aegisthus - the coup ${ }^{490}$ suspicion, suppression of rights, ${ }^{491}$ impiety, and murder, as well as several traits that are less common in tragedy such as the tyrant's bodyguard, ${ }^{492}$ threatened torture, ${ }^{493}$ and adultery (which is a form of the tyrant's sexual depravity). This early portrayal influences later portrayals of Aegisthus - he is portrayed as a tyrant in both Sophocles' and Euripides' Electra and is one of the more complicated examples.

Most of the tyrannical traits that have not yet appeared in the Agamemnon then appear in Antigone, around the same time as they appear in Herodotus' Histories. The stereotyped tyrant is by this point largely complete, but still lacks important moralising tropes. However, Sophocles considerably develops power-conserving tropes such as the phobos tropes that are earlier seen in Aeschylus. In Agamemnon, these are mostly confined to Aegisthus' fear of being overthrown, whereas, in Antigone, Creon's fear of being overthrown is constantly emphasised, as well as his mistreatment of advisors, fear of bribery, and need for flattery. The same is the case in Oedipus Tyrannus, where envy also plays a part. A more anachronistic portrayal of the tyrant's path to power as well as other emphasised tropes (e.g. anger and mistreatment of advisors) is also seen in the Prometheus Vinctus. Sophocles' and Euripides' plays also have more discussion about tyranny within the plays themselves, as we have seen in chapter two.

\footnotetext{
${ }^{488}$ Persae, Supplices and Seven against Thebes.

${ }^{489}$ Xerxes is an example of an eastern monarch (Perris, 2018).

490 Aesch., Ag., 1604-1611

491 The parrhesia of the Chorus: Aesch., Ag., 1618-1624; 1662-4

492 Aesch., Ag.,1649-1650

${ }^{493}$ Aesch., Ag., 1621-1623; 1631-2 (imprisonment); 1639-42
} 
In Euripides, there are new moralising tropes such as drinking and rape that do not appear in Aeschylus and Sophocles. However, we do not see further power-conserving tropes until the fourth century prose writers. Euripides' tyrants are generally less sympathetic than Sophocles' Oedipus and Creon and the combination of this with the development of tyrant tropes makes Euripides' nastiest examples closer to Plato's tyrant, than their earlier relatives. 


\section{Bibliography:}

Anderson, G. J. (2005). "Before turannoi were tyrants: rethinking a chapter of early Greek history," Classical Antiquity. 24(2): 173-222.

Andrewes, A. (1963). The Greek Tyrants. New York: Harper \& Row.

Arieti, J. and Barrus, R. J. N. (2007). Plato, Gorgias. Newport: Focus.

Bain, D. (1977). Actors and Audience: a study of asides and related conventions in Greek drama. Oxford: Oxford University Press

Brandenburg, P. J. (2005). "The second stasimon in Sophocles' Oedipus Tyrannus," L'Antiquité Classique: 29-40.

Carey, C. J. (1986). “The second stasimon of Sophocles' Oedipus Tyrannus,” The Journal of Hellenistic Studies. 106: 175-179.

Carty, A. (2015). Polycrates: Tyrant of Samos: New Light on Archaic Greece. Stuttgart: Franz Steiner Verlag.

Catenacci, C. (2012). Il tiranno e l'eroe: storia e mito nella Grecia antica. Rome: Carocci.

Cerri, G. (1982). “Antigone, Creonte e l'idea della tirannide nell'Atene del V secolo (Alcune tesi di V. Di Benedetto)," Quaderni Urbinati di Cultura Classica, 10: 137-155.

Dawe, R.D. (1982). Sophocles: Oedipus Rex. Cambridge: Cambridge University Press.

Dewald, C. (2003). "Form and Content: The question of tyranny in Herodotus," in Morgan, K. A. (ed.), Popular tyranny: sovereignty and its discontents in ancient Greece. Austin: University of Texas Press: 25-58. 
Dodds, E. R. (1961). Plato, Gorgias. A revised text with Introduction and Commentary.

Oxford: Clarendon Press.

Drews, R. (1972). "The first tyrants in Greece,” Historia: Zeitschrift für Alte Geschichte. (H. 2): $129-144$.

Easterling, P. (1985). "Anachronism in Greek tragedy," The Journal of Hellenic Studies. 105: $1-10$.

Ehrenberg, V. (1954). Sophocles and Pericles. Oxford: Blackwell.

Edmunds, L. (2002). “Oedipus as Tyrant in Sophocles' Oedipus Tyrannus,” Syllecta Classica. 13(1): 63-103.

Finglass, P. (2005). “Is there a Polis in Sophocles' Electra?” Phoenix, 59.3/4: 199-209.

Fisher, N. R. (1992). Hybris: a study in the values of honour and shame in Ancient Greece. Warminster: Aris \& Phillips.

Fleck, R.K., and Hanssen, F. A. (2013). "How Tyranny Paved the Way to Democracy: The Democratic Transition in Ancient Greece," Journal of Law and Economics, 56: 389-416.

Forsdyke, S. (2009). "The uses and abuses of tyranny", in Balot., R.K. (ed.), A companion to Greek and. Roman political thought. Oxford: Wiley-Blackwell: 231-246.

Gellie, G. H. (1964). "The second stasimon of the Oedipus Tyrannus," The American Journal of Philology, 85(2): 113-123.

Giorgini, G. (1993). La città e il tiranno: Il concetto di tirannide nella Grecia del VII-IV secolo $a C$. Milan: Giuffrè.

Graham, T. A. (2016). Playing the Tyrant: The Representation of Tyranny in Fifth-Century Athenian Tragedy (Doctoral Dissertation) 
Griffith, M. (1995). "Brilliant Dynasts: Power and Politics in the Oresteia," Classical Antiquities. 14(1): 62-129.

. (1999). Antigone: Sophocles. Cambridge: Cambridge University Press.

Hanson, V., D. (1999). The Other Greeks: The family farm and the agrarian roots of western civilisation. Berkley and Los Angeles: University of California Press.

Hester, D.A. (1977). “Oedipus and Jonah,” The Cambridge Classical Journal, 23: 32-61.

Hegyi, D. (1965). "Notes on the origin of Greek tyrannis," Acta Antiqua, 13: 303-318.

Irwin, T. (1979). Gorgias. Oxford: Clarendon Press.

Kallet, L. (2003). "Dēmos Tyrannos: Wealth, Power and Economic Patronage," in Morgan, K. A. (ed.), Popular tyranny: sovereignty and its discontents in ancient Greece. Austin: University of Texas Press: 25-58.

Kierstead, J. (2017). “Democracy's Humility: A Reading of Sophocles' Antigone," Polis, the Journal for Ancient Greek Political Thought. 34(2): 288-305.

Knox, B. M. (1966). Oedipus at Thebes. Oxford: Oxford University Press.

Lanza, D. (1977). Il tiranno e il suo pubblico. Turin: Einaudi.

McGlew, J. F. (1996). Tyranny and political culture in ancient Greece. Ithaca and London: Cornell University Press.

Mitchell, L. (2008). "Thucydides and the Monarch in Democracy". Polis: The Journal of the Society for Greek Political Thought, 25(1), 1-30. . (2013). The heroic rulers of Archaic and Classical Greece. London and New York: Bloomsbury Academic. 
Morris, J. (1996). "The strong principle of democracy", in Ober, J. and C. Hedrick, ed., Demokratia: A Conversation on Democracies, Ancient and Modern. Princeton: Princeton University Press.

Nilsson, M. P. (1929). "Die Hoplitentaktik und das Staatswesen”. Klio, 22(22), 240-249.

Oliva, P. (1982). "The early tyranny," Dialogues d'histoire ancienne. 8(1): 363-380.

O’Neil, J. (1986). "The semantic usage of tyrannos and related words," Antichthon. 20: 2640.

Parker, V. (1998). "Túpavvos. The semantics of a political concept from Archilochus to Aristotle," Hermes, 126(H. 2): 145-172.

Pearson, L. (1962). Popular ethics in ancient Greece. Stanford: Stanford University Press.

Perris, S. (2017). "Is There a Polis in Euripides' Medea?" Polis, the Journal for Ancient Greek Political Thought, 34(2): 318-335.

(2018). "Where have all the good men gone? Representations of oligarchy (and other regimes types) in Greek tragedy”, 2018 Classics Research Seminar Series, Wednesday 18th July, Victoria University of Wellington, Kelburn, Wellington. Seminar

Raaflaub, K. (2003). "Stick and glue: the function of tyranny in fifth-century Athenian democracy", in Morgan, K. A., (ed.), Popular tyranny: sovereignty and its discontents in ancient Greece. Austin: University of Texas Press.

Scodel, R. (1982). "Hybris in the second stasimon of the Oedipus Rex," Classical Philology. 77(3): 214-223.

Seaford, R. (1998). "Tragic money," The Journal of Hellenic Studies, 118: 119-139. . (2003a). "Tragic Tyranny," in Morgan, K. A. (ed.), Popular tyranny: sovereignty and its discontents in ancient Greece. Austin: University of Texas Press: 95-115. 
(2003b). "Dionysos, money, and drama," Arion: A Journal of Humanities and the Classics, 11(2): 1-19.

Sealey, R. (1960). "Regionalism in archaic Athens", Historia: Zeitschrift für Alte Geschichte, (H. 2): 155-180.

Sheppard, J. T. (1922). The Oedipus Tyrannus of Sophocles. Cambridge: Cambridge University Press.

Sidwell, K. (1992). "The argument of the second stasimon of Oedipus Tyrannus," The Journal of Hellenic Studies, 112: 106-122.

Simonton, M. (2017). Classical Greek Oligarchy: A Political History. Princeton: Princeton University Press.

Walters, K. (1982). "Geography and kinship as political infrastructures in archaic Athens," Florilegium 4: 1-31.

West, M.L. (2013). Hellenica: Selected Papers on Greek Literature and Thought. Volume II: Lyric and Drama. Oxford: Oxford University Press.

Williams, M.F. (2005). “ 'Because you spoke abuse against the king' ”: Parrhesia and Tyrannicide in Euripides' Medea" in Constantinidis, S.E., (ed.), Text and Presentation 2004. Jefferson and London: Mcfarland \& Company: 20-34.

Winnington-Ingram, R. P. (1971). "The Second Stasimon of the Oedipus Tyrannus," The Journal of Hellenic Studies, 91: 119-135. 